\title{
Rock Glaciers
}

JR Janke, Metropolitan State University of Denver, CO, USA

T Bolch, University of St Andrews, Scotland, UK

\begin{abstract}
Rock glaciers, a key element of alpine mountain geomorphic systems, consist of coarse surface debris that insulates an ice-core or ice-debris mixture. Rates of movement of active rock glaciers vary from 1 to more than $100 \mathrm{~cm} \mathrm{yr}^{-1}$. Rock glaciers exist in all major mountain ranges where permafrost occurs but are more common in dryer climates with high talus accumulation rates. New geospatial techniques, high-resolution data sources, and improved technology will contribute to a better understanding of these landforms. This chapter provides an in-depth summary of important research findings pertaining to rock glaciers and offers insight to future research.
\end{abstract}

\section{Keywords}

Climate change, Creep, Distribution, Field monitoring, Flow, Formation, Geospatial, Glacial, Hydrology, Periglacial, Permafrost, Photogrammetry and Remote sensing.

\subsection{Introduction}

High mountain systems, typically defined as having a large elevation ranges with a belt reaching above timberline that has been sculpted by glaciers and modified by periglacial processes (Troll 1973). Mountains are in the focus of geographic research as they influence weather and climate (Barry 2008), are an important source of fresh water (Immerzeel et al. 2020), and many processes are present which shape the mountains (Barsch and Caine 1984). Changes in mean annual air temperature (MAAT), net radiation patterns, snow cover distribution, glacier coverage and other variables will alter the processes modifying mountain systems (Beniston 2000; Beniston 2003; Slaymaker and Embleton-Hamann 2018). Humans, through anthropogenic 
climate change and recreational usage, threaten the nature and stability of high mountain systems (Barsch 1996; Konrad et al. 1999). Development in real estate projects, hiking paths, camping sites, transportation corridors, pipelines, ski lifts, communication towers, and utility towers continues to occur in alpine regions (Giardino and Vick 1987). As a result, mountains and humans have become delicately interconnected (Barsch 1996; Slaymaker and Embleton-Hamann 2018).

Rock glaciers are an important component of high mountain systems, characteristically serving as a visible indicator of mountain permafrost (Barsch 1996; Haeberli 2000) and occur at most mountain ranges on Earth (Table 1) (Figures 1-6) (Jones et al. 2018). Rock glaciers are important for the debris transport and storage in mountains (Humlum 2000; Gärtner-Roer 2012) and can also a source of hazards (Kääb et al. 2005; Delaloye et al. 2013; Schoeneich et al. 2015). They also store a significant amount of ice and can be of hydrological importance, especially in arid areas (Bolch and Marchenko 2009; Brighenti et al. 2019; Jones et al. 2019). Humans have used rock glaciers as a source for construction material, a backdrop for residential areas, dam abutments, drill sites, shaft and tunnel portals, and a water source for urban areas (Giardino and Vick 1987; Burger et al. 1999). Studying flow, age, ice content, formation, and climates of rock glaciers can provide a better understanding of geomorphic systems and processes in general and 
about the hydrological and geomorphological importance of rock glaciers and their response to climate change in specific. 


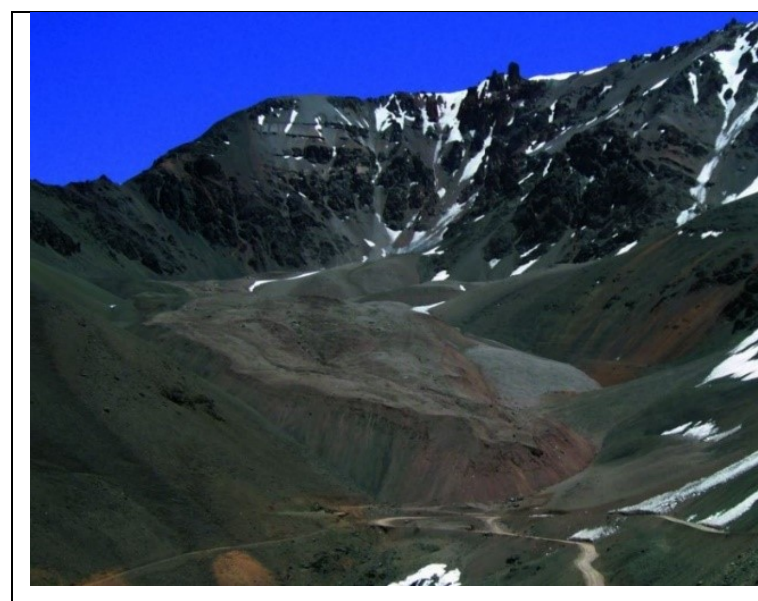

Figure 1 A rock glacier in Paso de Agua Negra, San Juan, dry Andes of Argentina. The road shown in the foreground is approximately $6 \mathrm{~m}$ wide.

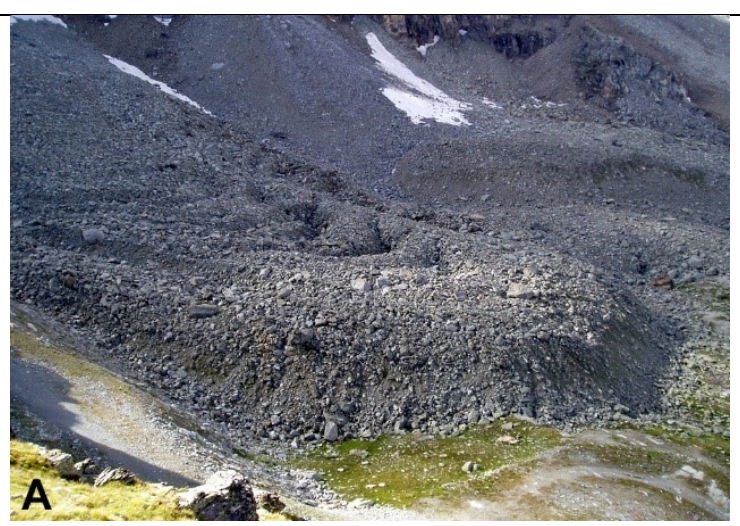

Figure 3 Murtél rock glacier at Piz Corvatsch, Upper Engadin, Switzerland. A $58 \mathrm{~m}$ borehole was drilled into this rock glacier in 1987. This represents one of the longest (and deepest) temperature measurements through alpine permafrost. (Photo: T. Bolch)

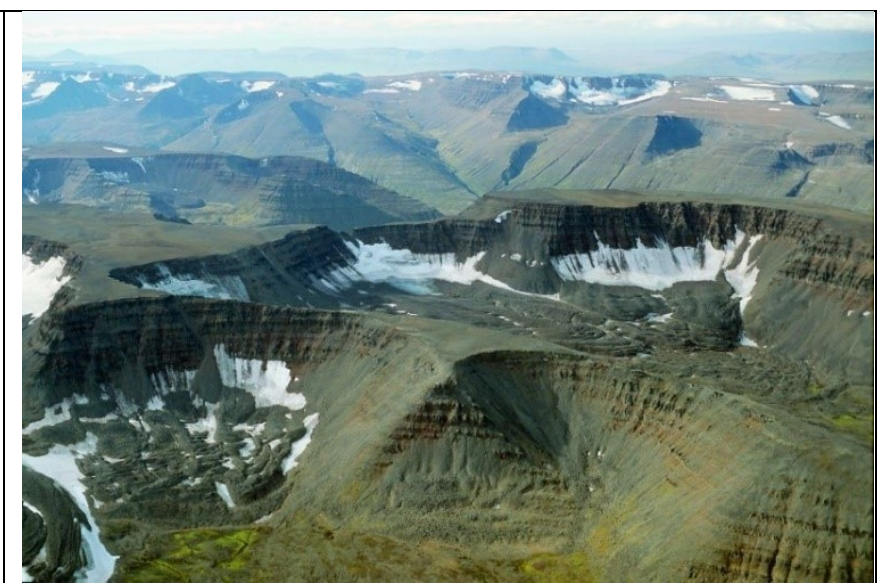

Figure 2 Rock glaciers nested in multiple cirques in northern Iceland.

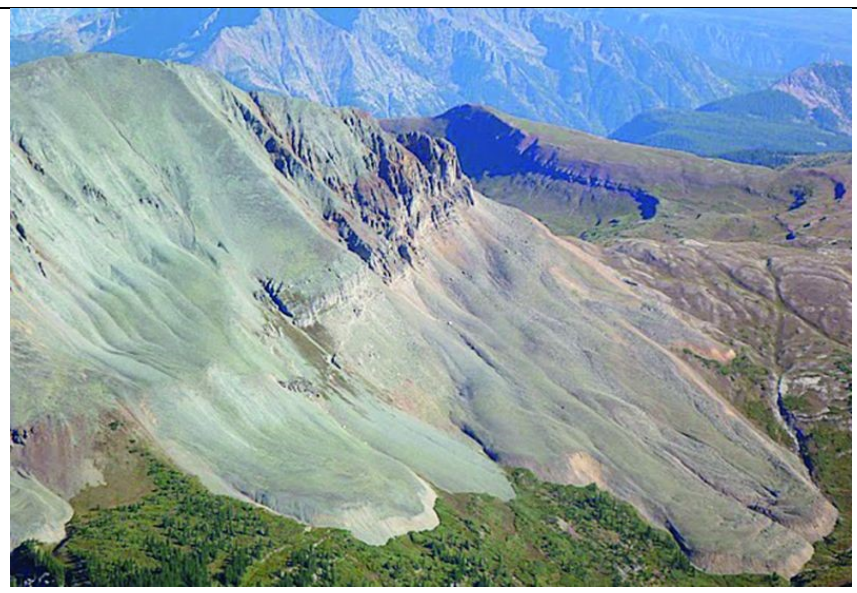

Figure 4 A rock glacier in the volcanic San Juan Mountains, CO, USA (Photo: JR Giardino) 


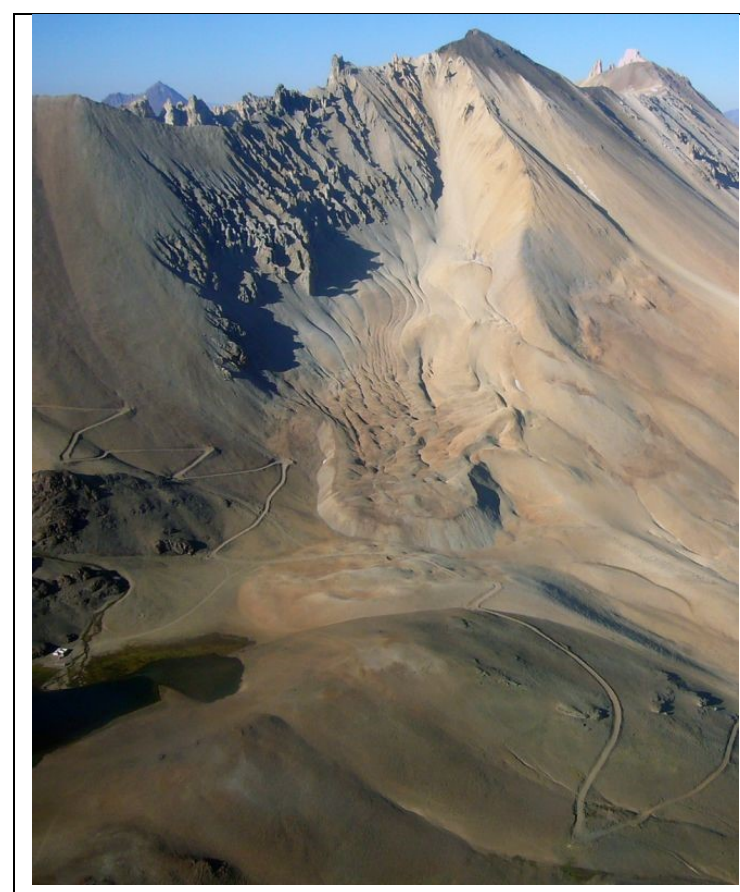

Figure 5 Cryogenic rock glacier near Las Leñas in the Central Andes of Mendoza, Argentina.

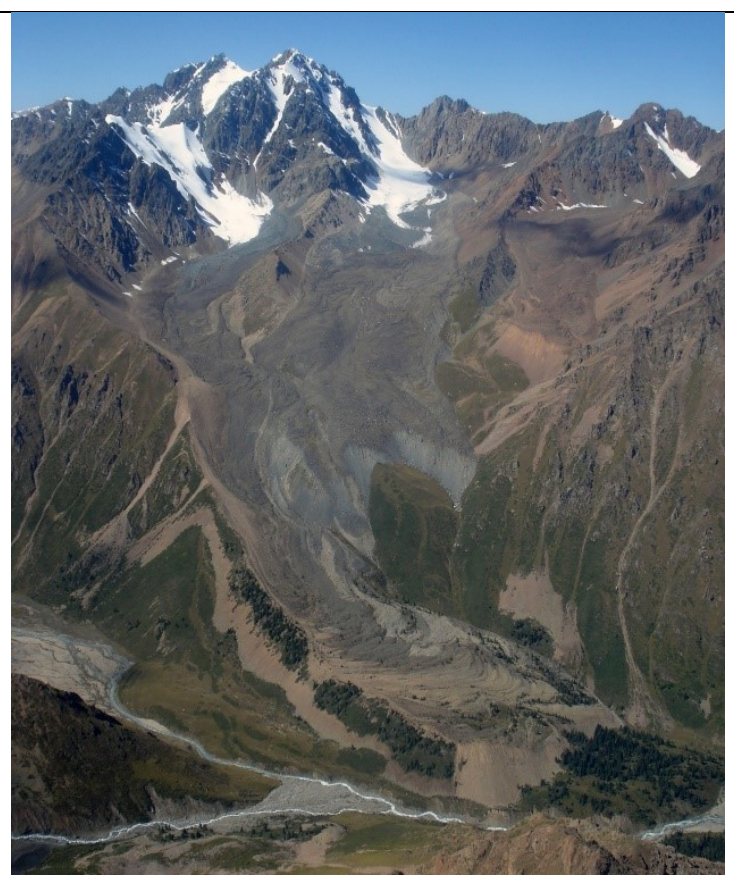

Figure 6: Ordzhonikisde rock glacier in Left Talgar Valley, Ile Alatau, Northern Tien Shan, Kazakhstan. Photo: V. Blagovechenskiy

\subsection{Definition and classification}

Early studies defined rock glaciers as a 'dead glacier' (Steenstrup 1883), a 'peculiar form of talus' (Spencer 1900), a 'rock stream' (Cross and Howe 1905), or even 'movement of masses in a glacier-like way' which create a 'wrinkled' pattern (Capps Jr 1910). In Russian literature, they were also called "wooden glacier" (Goloskokov 1949). Later studies included new variables, describing rock glaciers as a 'special form of moraine' (Gerhold 1964), 'ablation complexes' (Johnson 1974), and an example of the 'creep of alpine permafrost' (Haeberli 1985). Though scientific inquiry and debate have allowed our comprehension of these unusual alpine landforms to advance, our understanding continues to be refined and improved.

The rock glacier nomenclature has caused much confusion (Hamilton and Whalley 1995; Berthling 2011). The word 'glacier' implies glaciation; however, rock glaciers have been identified in areas that have not been glaciated. Rock glaciers could also be confused with rock 
streams, rock avalanche deposits, talus, or rubble if identified by surface morphology alone, even though the process of movement is quite different for each (Giardino et al. 1992). Hence, the activity and movement of the landform and processes associated with it must be considered. Thompson (1999) suggested that an analysis of fabric could help discriminate among talus, moraines, protalus ramparts, and rock glaciers. Rock glaciers exhibit various transitional features common to the alpine landscape; this makes it difficult to form a general standard definition. However, most rock glaciers demonstrate lobate or tongue-shaped forms resulting from a combination of glacial, nonglacial, and periglacial processes. More specifically, rock glaciers may be characterized according to a combination of the following variables: ice content, debris input (talus or moraines), rates of flow, size, location on the hillslope, microrelief (ridges and furrows), and distribution, which is influenced by lithology, geographic location, topographic and microclimates, and other local environmental variables (Wahrhaftig and Cox 1959; Washburn 1980; Martin and Whalley 1987; Vitek and Giardino 1987; Whalley and Martin 1992; Barsch 1996; Haeberli et al. 2006). At present, the widely accepted rock glacier definition is 'the visible expression of cumulative deformation by long-term creep of ice/debris mixtures under permafrost conditions' (Berthling 2011).

Rock glaciers have traditionally been classified as active, inactive, and fossil (relict) (Barsch 1996). Activity status is important since it can provide information about current and past climatic conditions (Sailer and Kerschner 1999; Frauenfelder et al. 2001). Active rock glaciers are mainly free of vegetation and have movement rates in the order of few decimeters to meters per year. Sharp crested, cascading front slopes and defined surface features indicate recent movement and are the key structure to identify active rock glaciers. Inactive rock glaciers still contain ice, but their movement has ceased in response to climatic change (the ice is melting or snow input has changed) or they have extended too far away from their debris source (Barsch 1996). As a result, they have less pronounced surface features and front slopes. Rounded crests and stable fronts with a mature lichen cover are related to inactive rock glaciers (Calkin et al. 1987) (Figure 7). Inactive rock glaciers typically contain alpine grasses, subalpine dwarf shrubs, 
or small patches of short trees (Burga et al. 2004). Fossil or relict forms are vegetated, no longer contain ice, and display surface collapse features (Barsch 1996).

It is important to note that a clear distinction is often impossible. Many processes operate on active, inactive, and relict rock glaciers other than those that refer to movement or ice content. As a result, descriptions of the processes that are responsible for flow or creep are favored. For example, chemical and physical weathering is still occurring on all rock glaciers, regardless of the rock glacier's active, inactive, or relict flow/creep status. Furthermore, the classification inherently implies that no other environmental or ecological processes are present in some forms; 
however, considering other ecological process, rock glaciers could provide an active habitat for animals, e.g., American pika populations (Millar and Westfall, 2010).
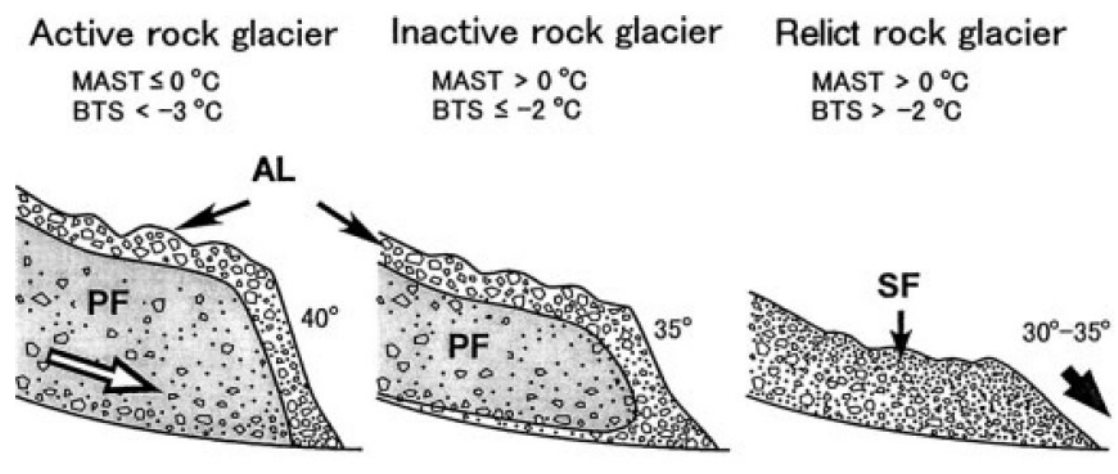

Longitudinal profile
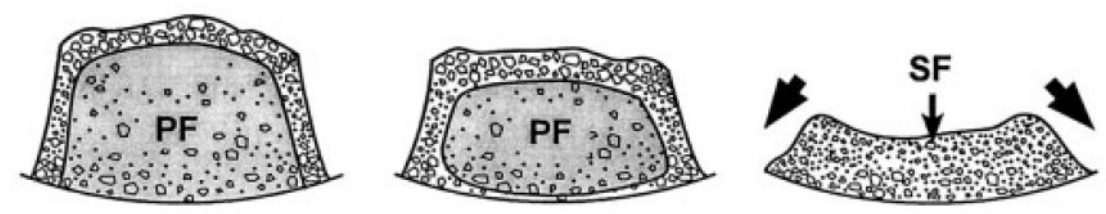

Transverse profile

AL: active layer

PF: permafrost

SF: seasonal frost

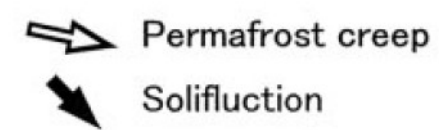

Figure 7: Schematic profiles of active, inactive, and relict rock glaciers. Source: Ikeda and Matsuoka (2002)

\subsection{Objectives}

The objectives of this chapter are to (1) address the current state of knowledge applied to rock glaciers, (2) discuss the techniques used by researchers to study the rock glaciers, and (3) provide topics for future rock glacier research.

\section{4 Rock Glaciers as Part of the Mountain System}

The surface of Earth, a patchwork of landforms, is shaped by various geologic and geomorphic processes that operate at different spatial and temporal scales. Rock glaciers are commonly a significant part of high mountain systems, consisting of summits and valleys with relief greater than $1000 \mathrm{~m}$, rugged topography, and steep slopes that average $35^{\circ}$ to $60^{\circ}$ reaching elevations above the treeline. Traditionally, mountain slopes have been classified using distinct processes. 
(Barsch and Caine 1984) designed a 4-tiered system with the following categories: (1) glacial, (2) coarse debris, (3) fine clastics, and (4) geochemical. The glacial system occurs at highest elevation and can transport debris from rockfall and erosion at the base of the glacier. The coarse debris system transfers material between cliffs, talus, and the features beneath them, including rock glaciers. Rock glaciers can contain a significant amount of debris/sediment (well above 20\%) (Otto et al. 2009). In the coarse debris system, movement is largely from mass wasting. The fine sediment system is an open system with input from aeolian sources. The material is exported from the mountain system to the fluvial system. In the geochemical system, solution weathering is important because of its consistency, although solute concentration remains minimal (Krautblatter et al. 2012).

The mountain classification system does not imply an always active, cascading system of energy and debris downslope from peaks to valleys. Certain mountains exhibit poorly developed linkages with little coarse debris occurring at lower elevations (Barsch and Caine 1984; Gerrard 1990; Müller et al. 2014; Slaymaker and Embleton-Hamann 2018) (Figure 8). This is supported by a rock glacier's slow movement (typically in the range of centimeter to decimeter per year) in comparison to the other types of mass movements such as landslides, debris flows, mudflows, or avalanches. Much of the work done is infrequent and random in its timing, resulting in a pulsed impact (Barsch and Caine 1984). Catastrophic events such as rockfalls and avalanches do much of the work in isolated areas such as on steep slopes, in areas of winter snow accumulation, or near glaciers (Caine 1974; Barsch and Caine 1984; Krautblatter et al. 2012). Rock glaciers 
represent a slow-moving, dynamic system that can maintain equilibrium for thousands of years (Burger et al. 1999).

\begin{tabular}{|c|c|c|}
\hline $\begin{array}{l}\text { Sedi ire it } \\
\text { syste in }\end{array}$ & $\begin{array}{c}\text { Klaphdagg } \\
\text { u nts }\end{array}$ & Sedirrent Fluxis:s \\
\hline 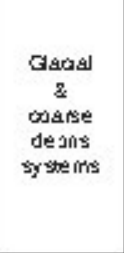 & 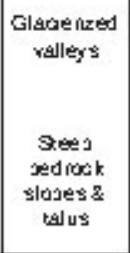 & $\begin{array}{l}\text { Snow } \\
\text { Foorifall sodanches Wudfows } \\
\text { 14.1) }\end{array}$ \\
\hline $\begin{array}{c}\text { Fine } \\
\text { sedi intent } \\
\text { syste in }\end{array}$ & $\begin{array}{l}\text { Waste } \\
\text { mantied } \\
\text { slojes }\end{array}$ & $\begin{array}{l}\text { Solfluctuon anda } \\
\text { soll cheed } \\
\text { |3.39] }\end{array}$ \\
\hline $\begin{array}{c}\text { Flumal } \\
z \\
\text { goeche inceal } \\
\text { syste ins }\end{array}$ & 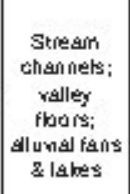 & $\begin{array}{l}\text { Solute trains out } \\
\text { (3.24) }\end{array}$ \\
\hline
\end{tabular}

(a)

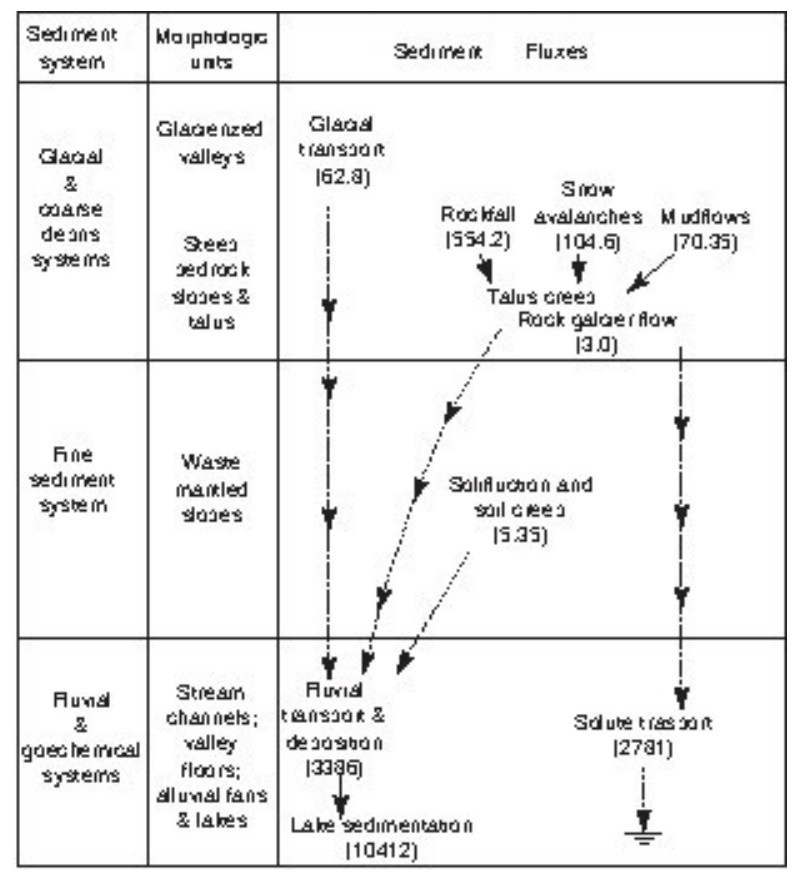

(b)

Figure 8 Sediment fluxes in two high mountain areas: (a) Williams Lake Basin, Colorado (Caine 1976) and (b) the Upper Rhine Basin (Jäckli 1956). Note that slow mass wasting accounts for less than $15 \%$ of the geomorphic work done. Their relative importance also decreases as the basin size increases. All fluxes are based on vertical transport $\left(10^{6} \mathrm{~J} \mathrm{~km}^{2} \mathrm{yr}^{-1}\right)$.

Adapted from Barsch, D., Caine, N. (1984).

\subsection{The Rock Glacier System}

As an individual component of the hillslope, rock glaciers can be described as an interconnected, cascading system of debris, ice, and water (Giardino 1979; Müller et al. 2014; Jones et al. 2019). The rock glacier system is comprised of four interrelated subsystems: cliff and talus, surface, subsurface, and outflow (Figure 9). The output from one subsystem provides input to another subsystem. For example, debris and meltwater from snow or ice are commonly transported from one subsystem to another. Surrounding cliffs provide coarse to fine talus inputs, depending on the patterns and density of headwall fractures and chemical and physical weathering of the 
surrounding bedrock cliffs (Haeberli et al. 1979; Giardino 1983; Müller et al. 2014). A rock glacier's continuous contact with the source area of talus helps maintain its form. If a rock glacier flows too quickly, the likelihood of loss of contact with the source area increases, and the subsystems will become disconnected. Snowmelt provides water to refreeze within the coarse debris of the rock glacier. The rock glacier acts as a storage unit for debris and ice but only transfers solutes out of the subsystem through summer melting (Jones et al. 2019). Coarse debris is characteristically contained within the system; however, glacial advances can transport debris out of the system. Other aspects of the system are open to external inputs and exhibit cascading characteristics. Aeolian material can be transported from other areas, deposited, and flushed from the system. Rock glacier solute potential has been shown to contribute to the geochemistry of 
alpine lakes and streams, which could affect other system's water quality (Vitek et al. 1981;

Williams et al. 2006; Baron et al. 2009; Jones et al. 2019)

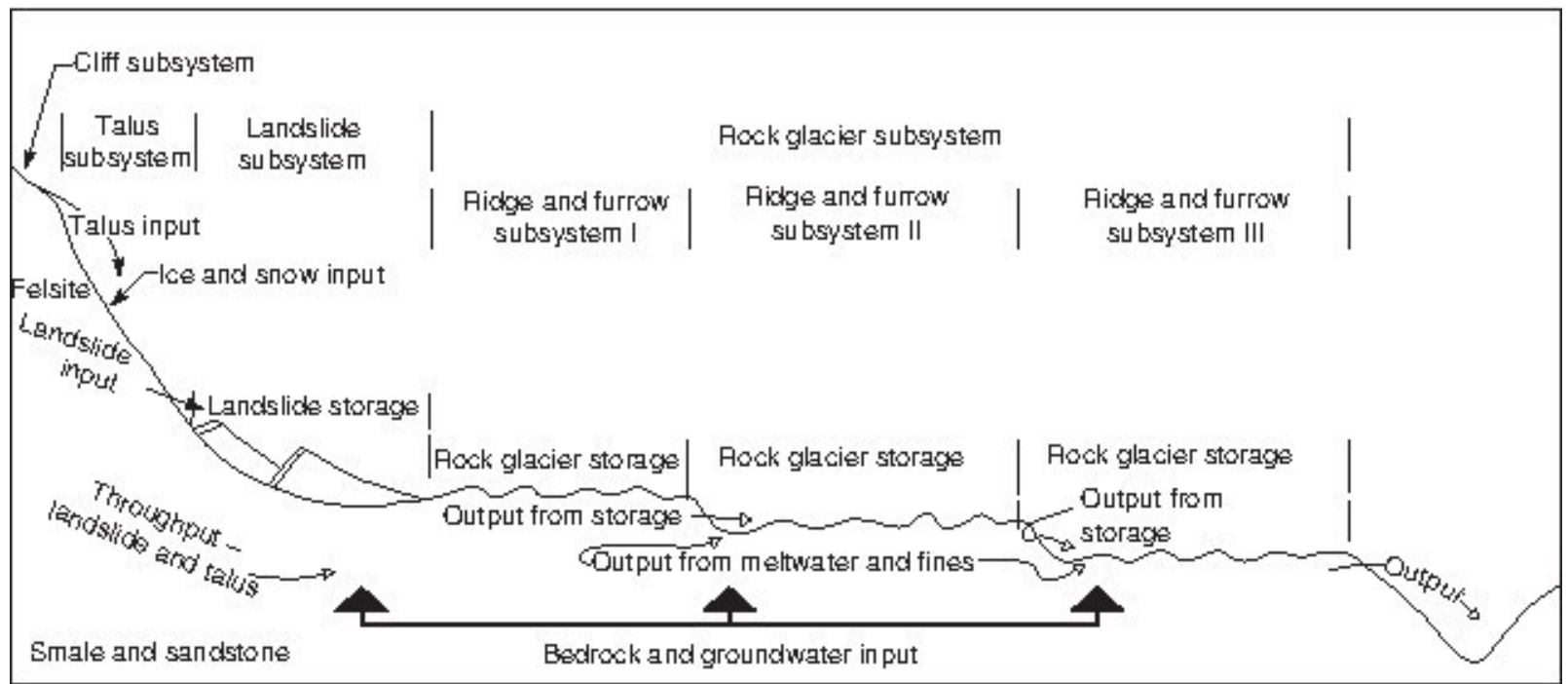

(a)

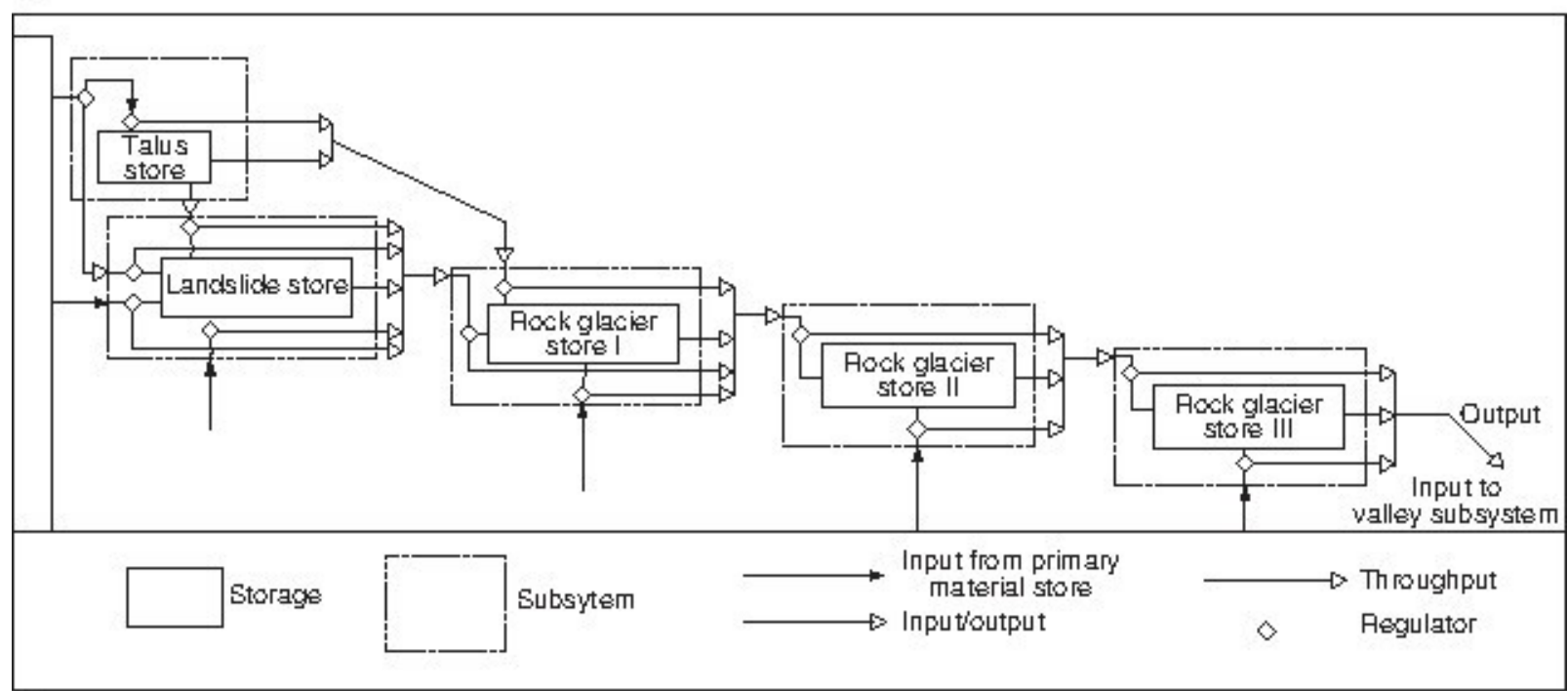

(b)

Figure 9 The rock glacier system (a) and storage and subsystems within the rock glacier system (b). Adapted with permission from Vitek, J.D., Giardino, J. (1987). 


\subsection{Form}

From their research in the Alaska Range, Wahrhaftig and Cox (1959) provided a classification framework based on shape. Lobate rock glaciers have single or multiple lobes with a greater width than length, whereas tongue-shaped rock glaciers are longer, extending downslope, usually from a cirque. Spatulate rock glaciers resemble tongue-shaped rock glaciers but display an abrupt widening beyond lateral topographic constraints (resembles a piedmont glacier). Subsequent studies used classifications based on topographical or geographical descriptors such as valleywall, valley-floor, protalus, debris, talus, or glacial (Outcalt and Benedict 1965; Linder and Marks 1985; Barsch, 1988; Barsch 1996; Humlum 1998). In the Swiss Alps, pebbly rock glaciers contain abundant matrix, but are smaller because of less resistant source rockwall. In contrast, bouldery rock glaciers (clast sizes 15-20 cm) with less matrix and less resistant source walls are smaller (Ikeda and Matsuoka 2006). A single classification scheme has not gained widespread 
acceptance; however, a subset of Wahrhaftig and Cox's (1959) classification most commonly appears in the literature (Figure 10).

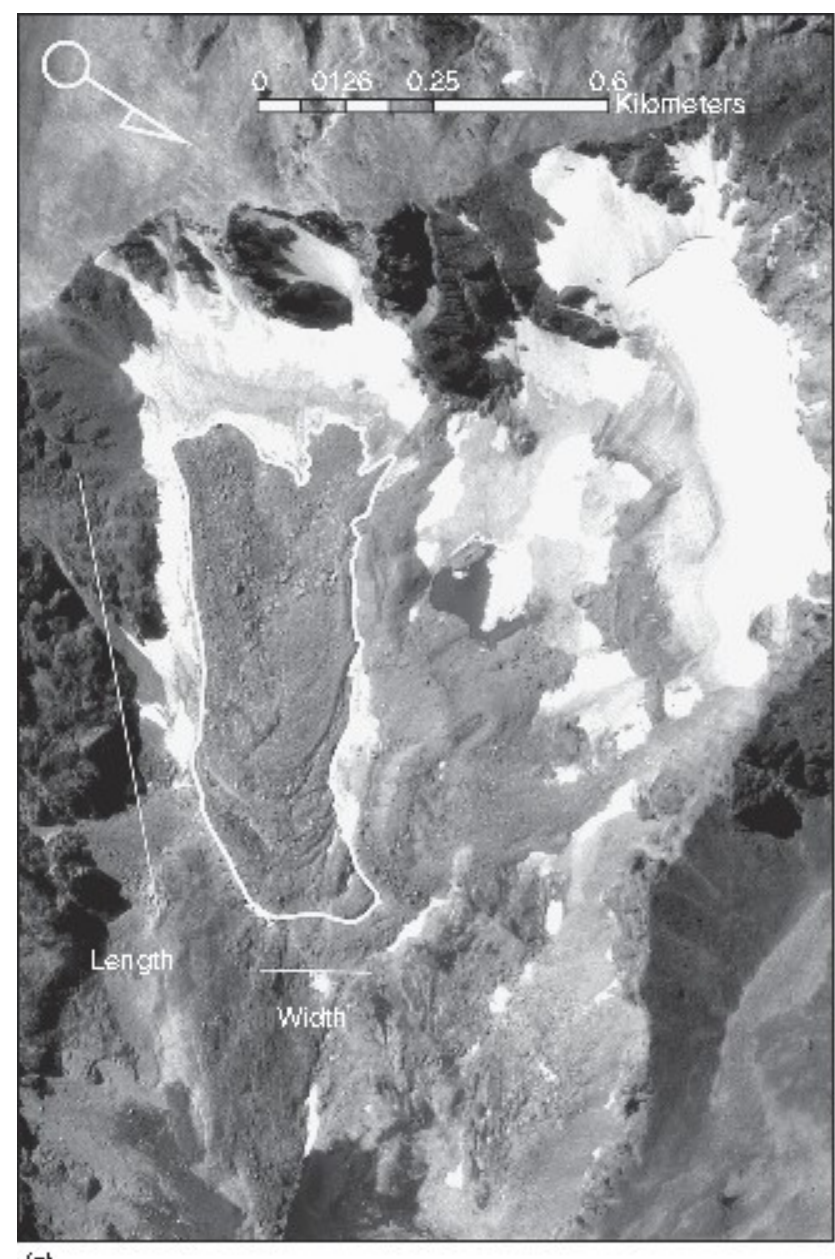

(a)

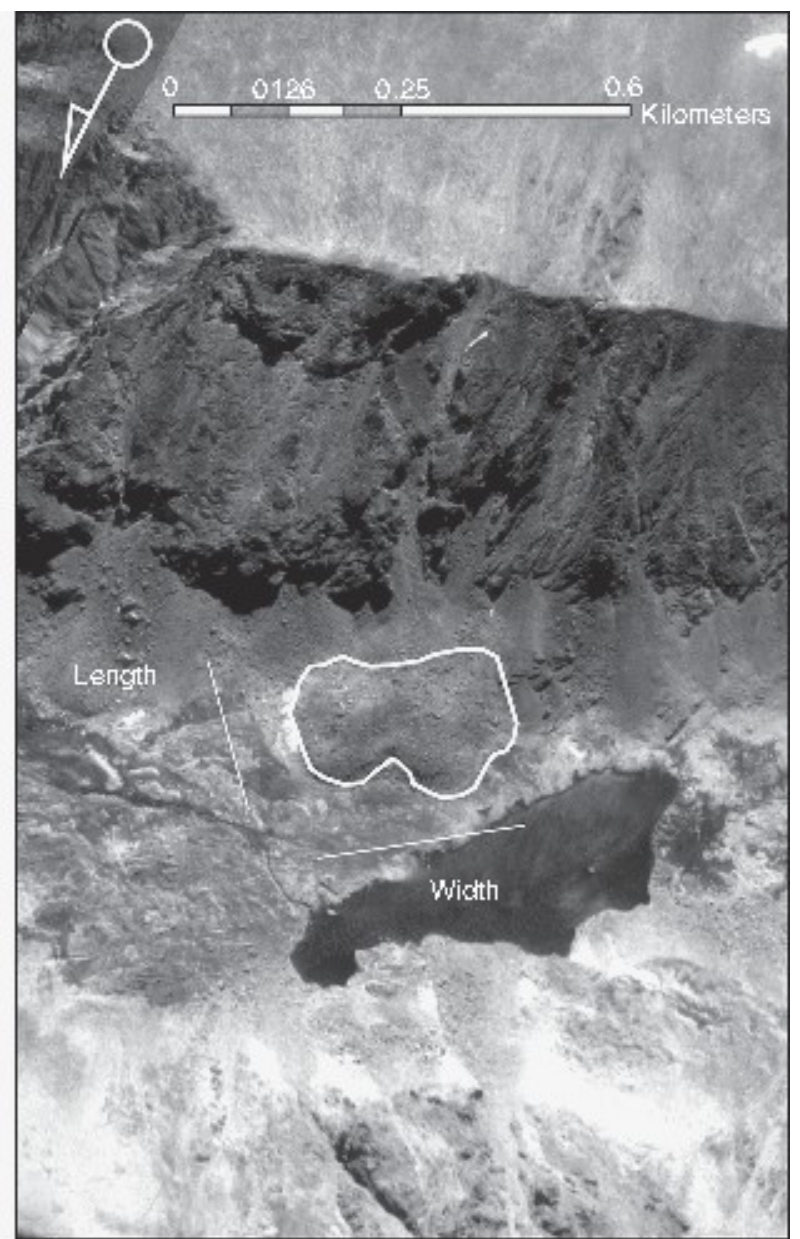

(b)

Figure 10 Typical tongue-shaped (a) and lobate (b) rock glacier forms are illustrated by aerial photos of the tongue-shaped Arapaho rock glacier and Green Lake 5 lobate rock glacier in the Front Range, CO.

\subsection{Surface Morphology}

The surface of a rock glacier consists of mostly mixtures of poorly sorted, angular, blocky rock debris at slopes that are often less than $25^{\circ}$. Rock glaciers that are flowing or creeping exhibit 
pronounced ridge and furrow complexes, resembling a viscous substance such as pahoehoe lava (Vitek and Giardino 1987; Barsch 1996). Active rock glaciers that are moving are mostly devoid of vegetation and comprised of distinct ridges and furrows. Transverse ridges and furrows form perpendicular to the direction of movement, appear bowed in nature, and originate from overthrusting of internal shear planes, differential movement of distinct layers, or changes in debris supply (Wahrhaftig and Cox 1959; Haeberli 1985; Burger et al. 1999; Kääb and Weber 2004); Janke, 2005d). Longitudinal ridges and furrows form parallel to the principal direction of movement and result from extensional flow, resistance to flow, or are remnants of lateral moraines (Calkin et al. 1987; Ackert 1998)).

Rock glaciers exhibit a combination of transverse and longitudinal ridges and furrows. On the edges of the rock glacier, longitudinal ridges may occur, whereas toward the middle, they may be transverse. Ridges and furrows are commonly arched downslope in the lower parts of the rock glacier. In addition, rock glaciers may have a tightly meandering furrow that extends lengthwise down the rock glacier (Wahrhaftig and Cox 1959). Because of thermokarst or ice ablation, the surface morphology of rock glaciers can also appear mottled with spoon-shaped depressions (Washburn 1980). Advancing (active) rock glaciers have a steep front slope near the angle of repose with large boulders present at their toes, but near the head or rooting zone (similar to a bergschrund near the head of a glacier), there is a gradual transition from the source of debris input to the rock glacier (Figure 11) (Vitek and Giardino 1987; Barsch 1996; Müller et al. 2014). In general, the curvature is a concave upward profile near the head of the rock glacier and convex toward the toe. Visible surface structures and supporting information about the 
internal structure can explain the development and movement of rock glaciers. Figures 11-16 illustrate some of the features that characterize rock glaciers.

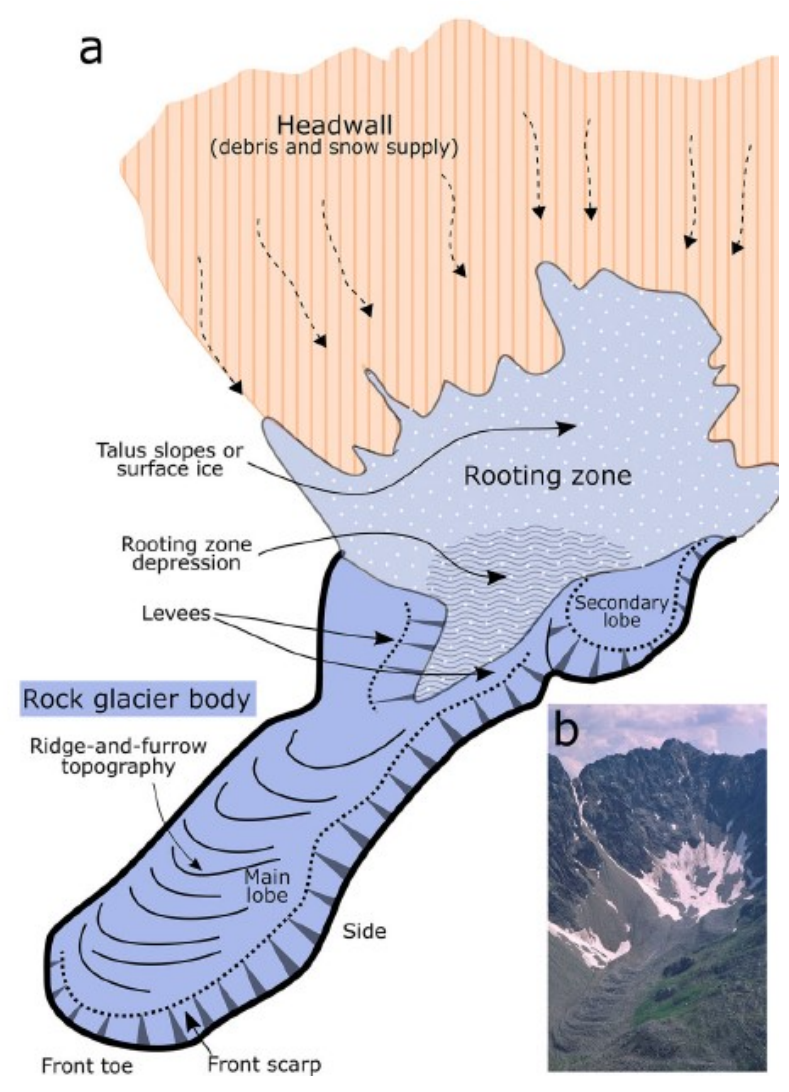

Figure 11 Schematic diagram illustrating the main morphological components of a typical tongue-shaped rock glacier and (b) the corresponding field photograph. Buco del Cacciatore, Valtellina, Central Italian Alps (photo courtesy of Mario Butti). Source: (Brardinoni et al. 2019) 


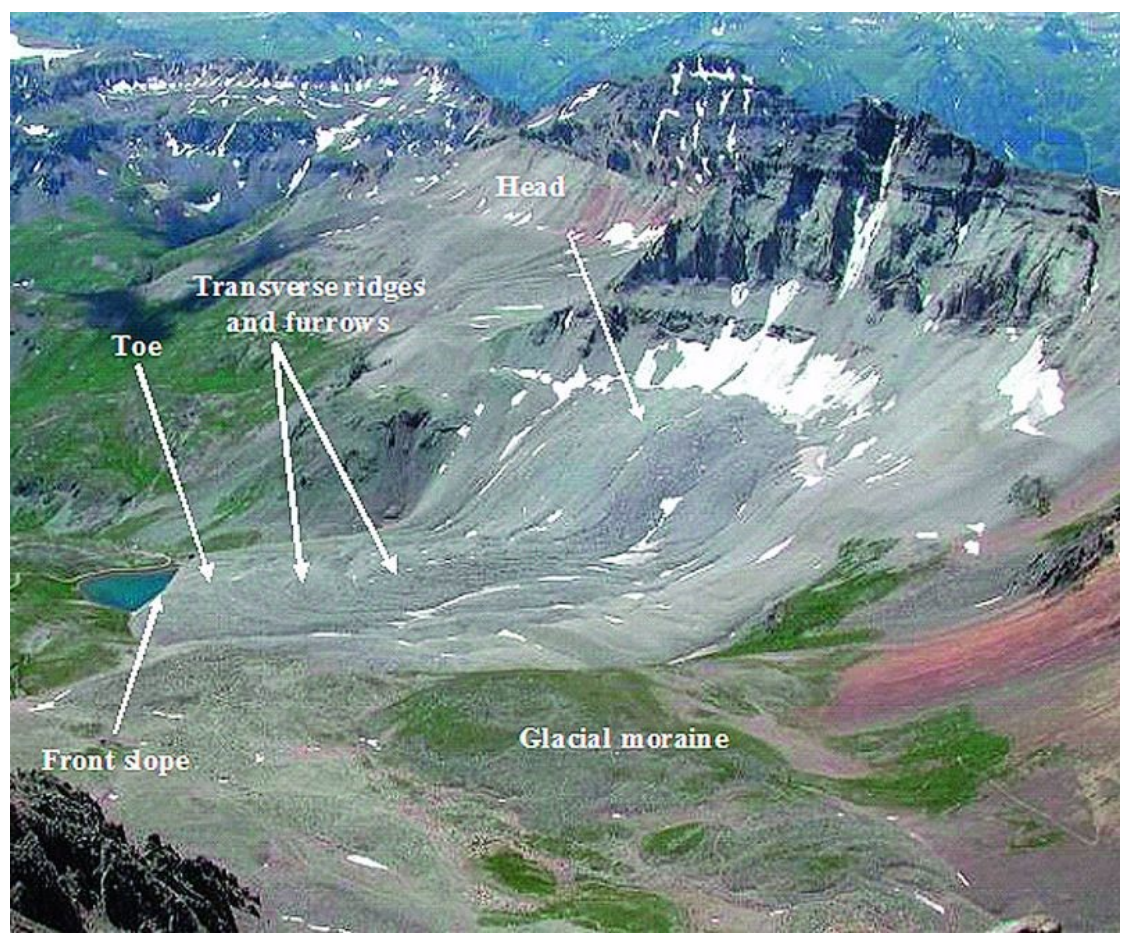

Figure 12 Some surface features of the tongue-shaped Yankee boy basin rock glacier in the San Juan Mountains, CO. Adapted from Degenhardt, J.J. and Giardino, J.R. (2003).

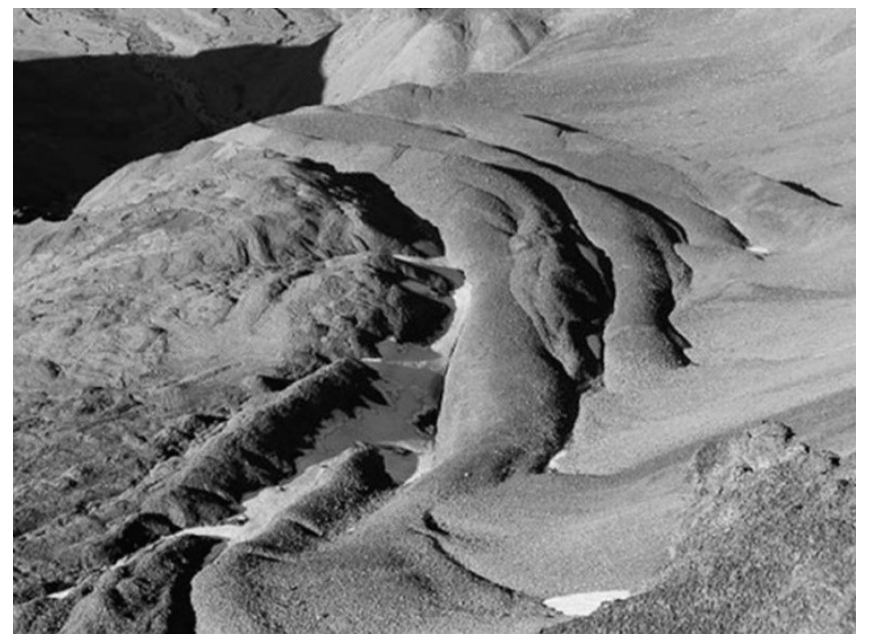

Figure 13 This rock glacier at Larsbreen, Svalbard, exhibits a unique longitudinal ridge and furrow complex. The ridges emanate from convergence of talus cones (not shown), whereas the furrows are associated with slower deposition from divergence between cones.

Adapted from Humlum, O. (1997). 


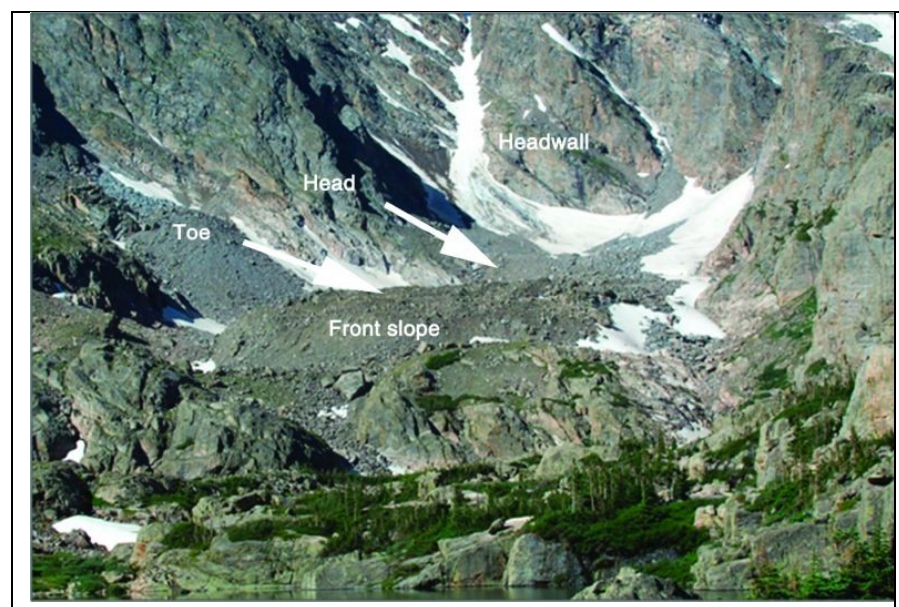

Figure 14 A terrestrial photograph of the tongueshaped Taylor rock glacier in Rocky Mountain National Park, CO. A small lobate rock glacier emanates from the corridor to the left. (Photo: J. Janke)

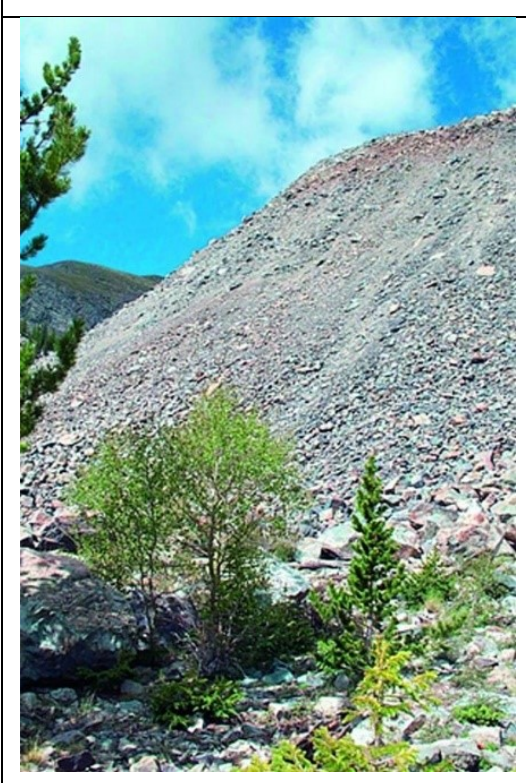

Figure 16 Front slope near the toe of California rock glacier in the Sangre de Cristo Mountains of Colorado (slope $\approx>35^{\circ}$; height $\approx 45 \mathrm{~m}$ ). (Photo: J. Janke)

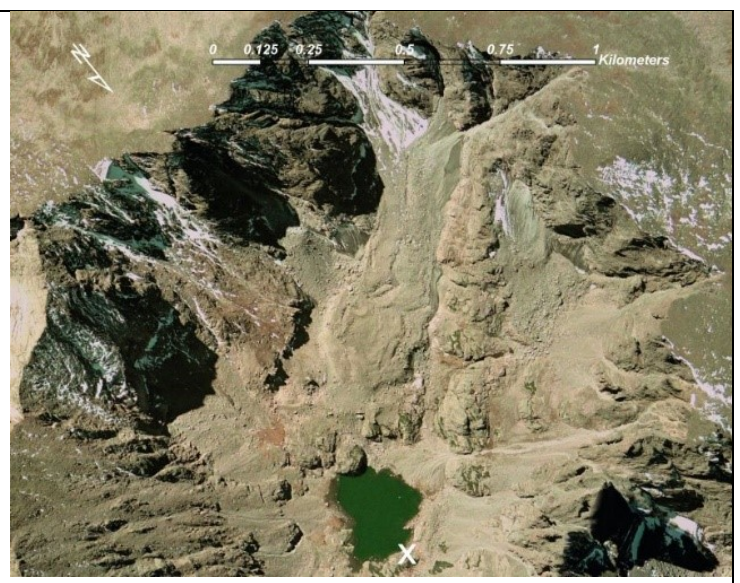

Figure 15 An aerial photograph of Taylor rock glacier. Vantage point of the previous photo is shown with an ' $\mathrm{X}$.' 


\subsection{Rock glacier mapping and inventorying}

Exact knowledge about the occurrence of the rock glaciers is important for many reasons such as creating a understanding of the mountain systems, the hydrological importance of rock glaciers, and improve hazard assessments. The distinct characteristics described here allow rock glaciers to be identified and mapped in the field and using remote sensing data. In earlier times, aerial photographs were the main source for rock glacier mapping (e.g., (Wahrhaftig and Cox 1959; Titkov 1988; Gorbunov and Titkov 1989; Guglielmin and Smiraglia 1998), while nowadays satellite images are used. The increasing availability of high-resolution satellite images and GoogleEarth allows even smaller rock glacier to be detected and larger areas to be mapped. Our understanding of rock glaciers has improved in recent years, in particular for the European Alps (Cremonese et al. 2011; Kellerer-Pirklbauer et al. 2012; Krainer and Ribis 2012; Scotti et al. 2013; Colucci et al. 2016), Rocky Mountains (Charbonneau and Smith 2018), Andes (Esper Angillieri 2009; Falaschi et al. 2014; Rangecroft et al. 2014; Falaschi et al. 2015; Janke et al. 2015; Barcaza et al. 2017), Carpathian mountains (Onaca et al. 2017), High Mountain Asia including the Tibetan mountains and the Himalaya (Schmid et al. 2015; Jones et al. 2018; Reinosch et al. 2021) and the Tien Shan (Bolch and Gorbunov 2014; Wang et al. 2017; Blöthe et al. 2019; Bolch et al. 2019; Kääb et al. 2021). However, although rock glacier inventories exist for many parts of the Earth, larger areas are still missing.

Almost all of the available inventories were generated manually by on-screen digitizing. However, mapping approaches and definitions are varying amongst the studies and inventories. A promising method to automatically and objectively map rock glaciers using satellite data and GIS modelling was proposed by (Janke 2001). (Brenning 2009) used digital elevation data along with satellite imagery and statistical models to detect rock glaciers. Modern machine learning techniques, combined with the availability of high-resolution data, allow further automatization of rock glacier mapping (Robson et al. 2020). Although these methods are promising, the uncertainties are still large and require manual correction if an accurate inventory is to be generated. While the rock glacier fronts are usually identifiable, the rock glacier head is often difficult to define due to a smooth transition to the upslope area. An intercomparison exercise revealed large deviation of the rock glacier outlines digitized by different experts especially in the upper regions (Brardinoni et al. 2019). Additional information such as differential 
interferometric synthetic aperture radar (DInSAR) or hillshades derived from high-resolution DEMs supports the mapping of rock glaciers (Barboux et al. 2014; Necsoiu et al. 2016; Wang et al. 2017; Villarroel et al. 2018 Kääb et al. 2021) (Figure 17).

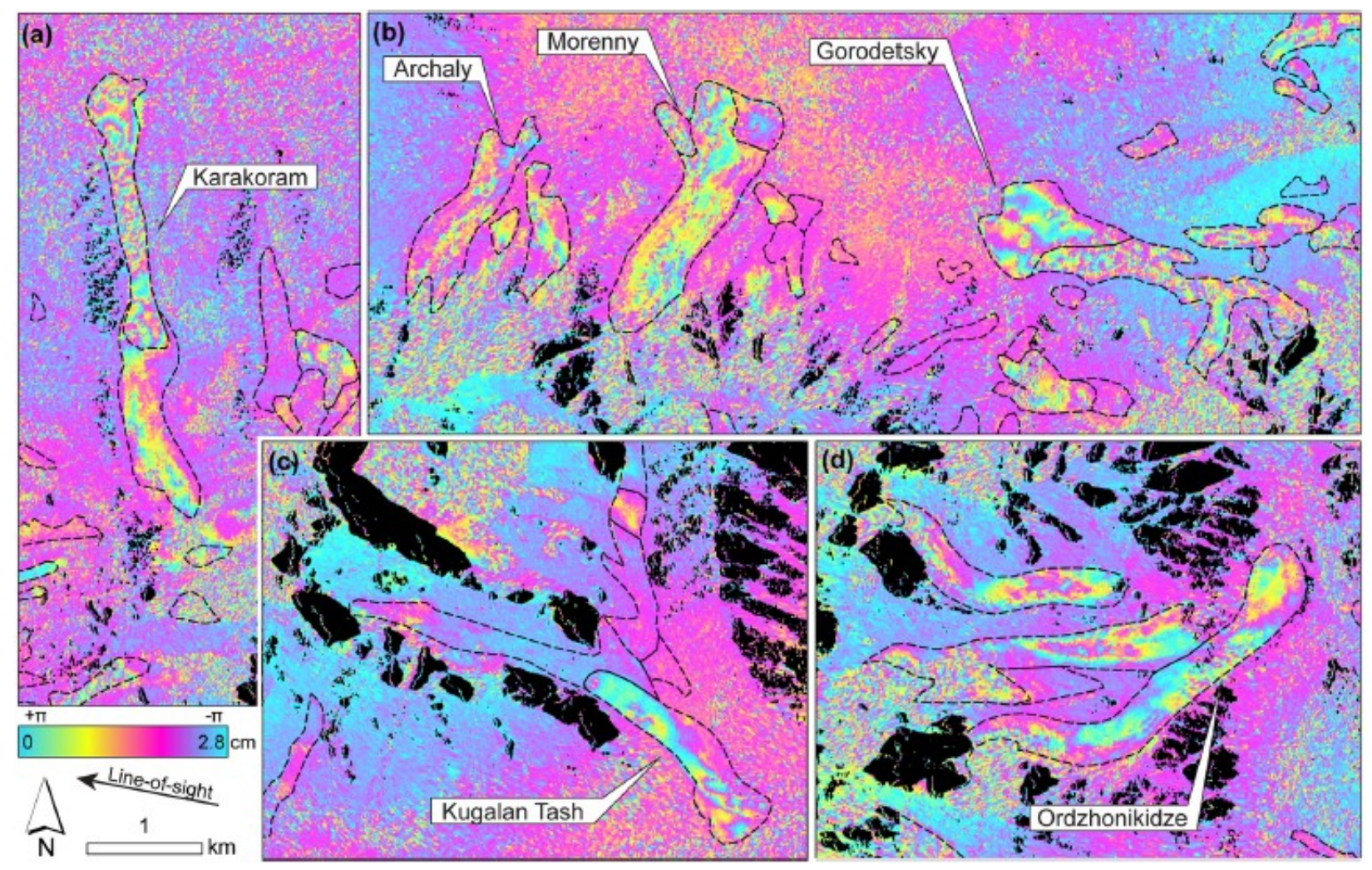

Figure 17 Radar Interferograms to support rock glacier mapping (Example from Northern Tien Shan); Source: Kääb et al. 2021

A rock glacier inventory should include the outlines and information about the location and area as well as topographic information which can be obtained from available digital elevation models. Another important variable is the activity of the rock glacier. The activity can be estimated based on the surface morphology (see previous sections) and vegetation cover. Moreover, total plant cover and floristic composition vary between inactive and active forms. Unstable sites are characterized by vascular species tolerating surface instability (Cannone and Gerdol 2003). Inactive rock glaciers typically contain alpine grasses, subalpine dwarf shrubs, or small patches of short trees (Burga et al. 2004). However, vegetation might not grow in arid or very cold alpine regions, and hence a clear distinction is often not possible using single images as the only source of information. Activity status is further complicated by lobes of activity 
superimposed on the surface of previously active rock glaciers or slope deposits (KellererPirklbauer et al. 2008). Therefore the term "intact" can be used for both active and inactive rock glaciers is preferred (Brenning 2005; Kofler et al. 2020). Although it is relatively difficult to calculate, the basal shear stress can be used to differentiate active and inactive categories. Giardino and Vick (1987) determined that basal shear stress for active rock glaciers lies between 1.0 and 2.0 bars, and Wahrhaftig and Cox (1959) determined that basal shear stress for inactive rock glaciers is less than 1.0 bars. Remote sensing allows the clearest information about the activity, especially InSAR can detect even a centimeter range displacements (Barboux et al. 2014). The working group for rock glacier mapping recommendations is currently working on standardized guidelines and recommends both using high-resolution optical data and InSAR measurements (IPA Action Group 2020).

\subsubsection{Origin and Internal Structure}

Geophysical investigations (such as ground penetrating radar, seismic refraction, or electrical resistivity tomography) and boreholes from a few rock glaciers provide insights into the internal structure of rock glaciers. It was found that the structure can be generalized as a three-tiered system with a top layer of rock fragments with a thickness of about one to a few meters covering an ice-cemented or ice-cored interior with a thickness in the order of tens of meters, and finally, 
a layer with low or no ice content that overlies rock deposited and overridden by the top layers (Humlum 2000; Hausmann et al. 2007; Springman et al. 2012) (Figure 18).

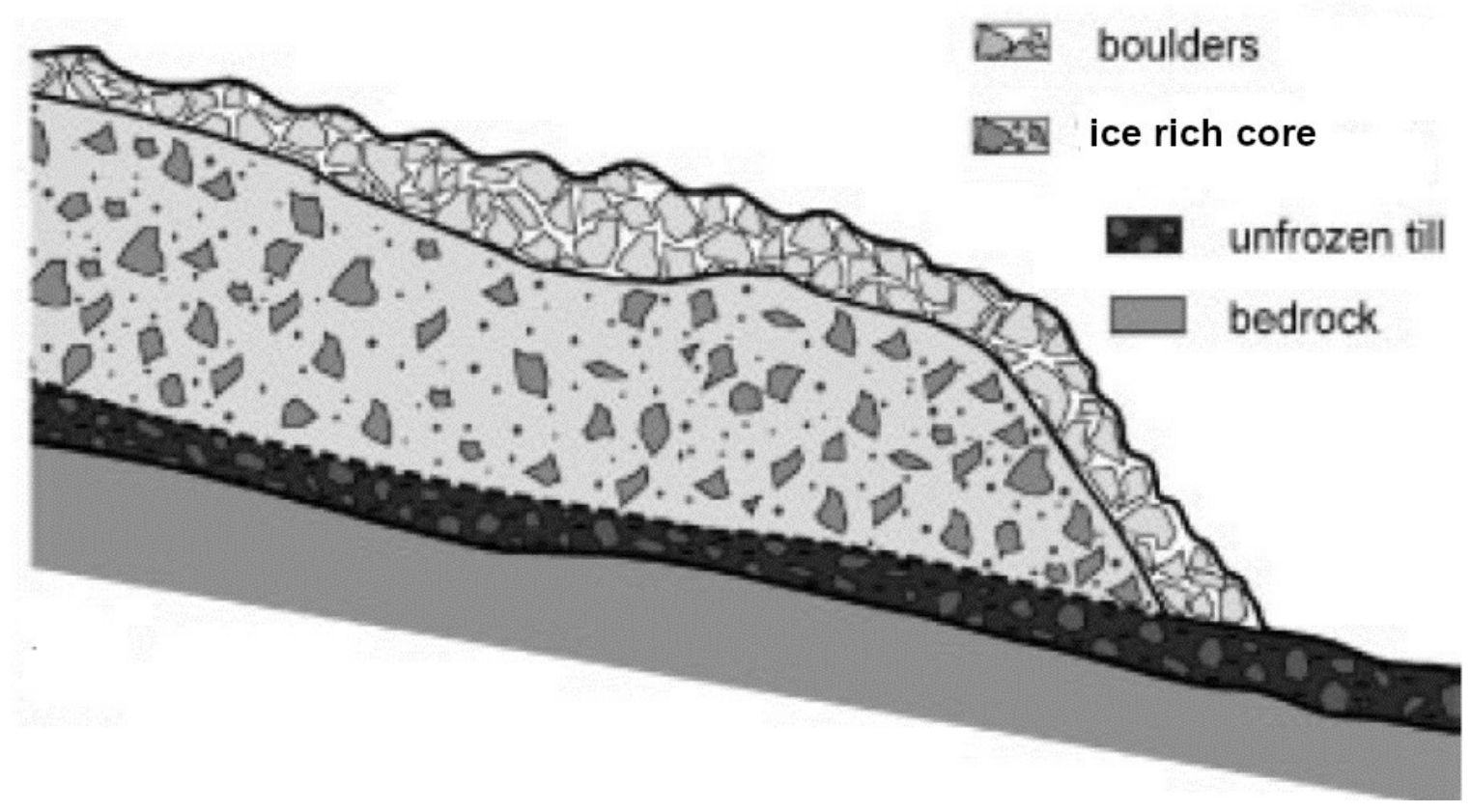

Figure 18 Schematic figure of the structure of a typical rock glacier. Note: The core consists of variable ice and debris content. Source: after Hausmann et al. 2007.

A rock glacier's periglacial or glacial origin is commonly debated, relating to whether or not rock glaciers have an ice-cemented or ice-cored internal structure (Figures 19 and 20). Supporters of the periglacial model believe that cemented ice in the form of interstitial ice (pore-ice) or segregated ice (ice lenses) produces creep (Wahrhaftig and Cox 1959; Barsch 1996; Haeberli et al. 2006). Giardino (1979) hypothesized that hydrostatic pressure could help explain the movement of ice-cemented rock glaciers. Supporters of a glacial model advocate an ice-cored 
structure in which a relict glacier has been buried by debris (Potter 1972; Whalley 1974; Whalley and Azizi 1994; Potter et al. 1998). Abundant evidence supports each of the models.

\subsubsection{Ice-cored Structure}

Evidence for an ice-core has stemmed mainly from the research of rock glaciers in North America, particularly Galena Creek rock glacier in the Absaroka Mountains of Wyoming where the debate began when Potter (1972) observed an ice-core in the rock glacier. Using seismic data, he found evidence of a 1-1.5 m thick debris mantle underlain by an ice core with a thickness of 40-80m. More detailed investigations confirmed these initial findings (Potter et al. 1998). Larger variability of the debris mantle had a tendency to thicken down slope. Further evidence was found by Clark et al. (1996), who recovered a $9.5 \mathrm{~m}$ core of continuous ice. The 2000 -year-old ice-core consists of $90 \%$ clean, bubbly ice and shows a good correlation with late summer ablation layers for an ice-core obtained from South Cascade glacier in Washington. Peaks in $\delta^{18} \mathrm{O}$ correspond closely with the location of the debris bands; this represents warm precipitation from the late summer or early fall and correlates well with records from other temperate glaciers. Recent detailed geophysical investigations using GPR revealed the existence of reflectors that form a network of concave layers dipping upslope (Petersen et al. 2020). The authors interpret these as debris bands formed by debris falls and subsequently buried by snow and ice accumulation.

Benedict (1973) also found ablation surfaces on Arapaho rock glacier in the Colorado Front Range. The ablation surfaces were dipped up-valley at angles of 32 to $60^{\circ}$, suggesting a glacial origin. Arapaho rock glaciers could have formed during a catastrophic rockfall event that covered the former glacier, given the steep cirque walls and abundance of massive boulders located near the head (Whalley 1974). Similar processes have been observed in Scotland, where landslide debris is believed to cover and form rock glaciers (Ballantyne and Stone 2004). GPR data in the San Juan Mountains of Colorado suggests a similar formation method for some rock 
glaciers (Degenhardt 2009). A new core drilled in the rock glacier Murtèl (Swiss Alps) in 2015 also revealed a core with very high ice content (unpublished data).

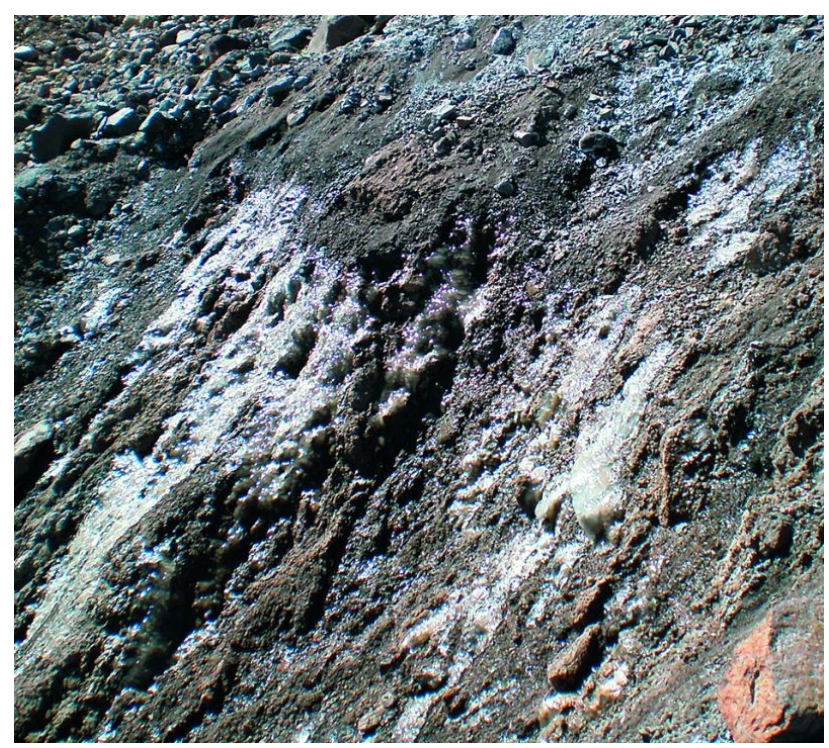

Figure 19 Interstitial ice found in the Elqui Catchment near the Las Tórtolas Mountain, Chile.

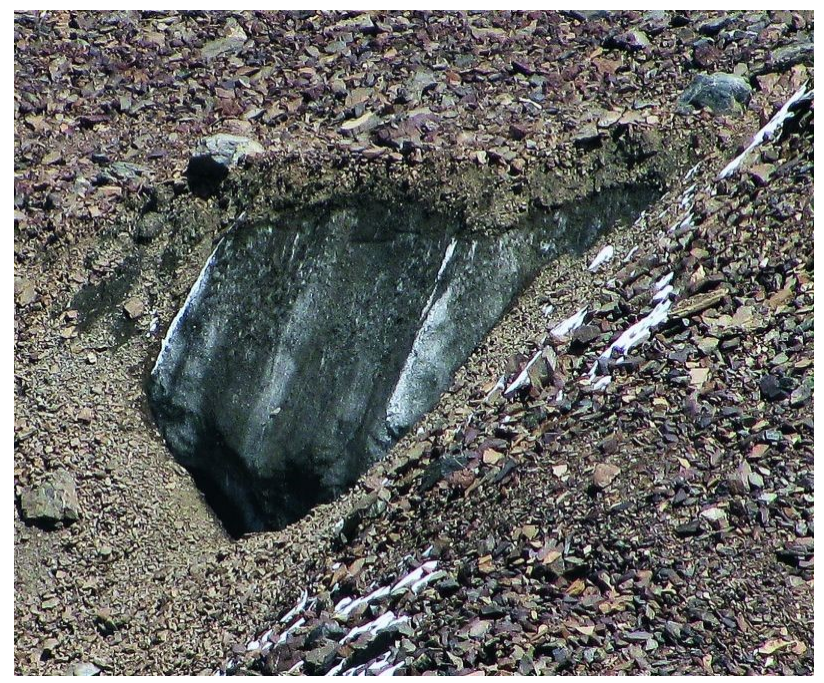

Figure 20 Internal ice-core structure on a debris-covered/rock glacier complex in the Pamir (Tajikistan).

\subsubsection{Ice-Cemented Structure}

Evidence of ice-cemented structures comes from various sources (Wahrhaftig and Cox 1959; Haeberli 1985; Barsch 1987; Barsch 1996; Moore 2014). In their survey of rock glaciers in the 
Alaskan Range, Wahrhaftig and Cox (1959) hypothesized that interstitial ice within the rock glacier forms from compacted snow, freezing of water derived from melting snow or percolation of rain, or groundwater that rises beneath the talus and freezes on contact with cold air. Barsch (1977) stated that there is no need for glacier ice if talus production is high and snow avalanches and refrozen meltwater are available. Based on existing data and seismic investigations on Gelena Creek rock glacier, Barsch $(1987,1988,1996)$ concluded that the landform is a multiunit rock glacier. The permafrost model is based on the presence of talus. Talus is incapable of much movement unless ice is present. To generate enough ice capable of movement, segregated ice can form where water flows over the permafrost layer. By hydrostatic pressure, water remains in contact with the permafrost, and thus ice lenses can grow (Whalley and Martin 1992). Perhaps the strongest argument relies on the fact that rock glaciers have been identified in areas that have not been glaciated. For example, Barsch and Updike (1971) mapped fossil rock glaciers at Kendrick Peak, AZ, and San Mateo, NM in areas that were not glaciated, thus must be of periglacial origin. Mt. Mesta rock glacier in southern $\mathrm{CO}$ is another example of a rock glacier that formed in nonglacial conditions (Giardino and Vitek 1988b). In the Sleza Massif in southwest Poland, relict rock glaciers are likely of periglacial origin (Zurawek 2002).

\subsubsection{Continuum}

Because abundant evidence exists for each of the models, others have supported the idea of a landscape continuum, a cycle describing the transition among glaciers, rock glaciers, and slope deposits, or a composite model where a combination of processes is responsible for creating rock glaciers (Shroder 1987; Giardino and Vitek 1988a; Corte 1987; Johnson 1987; Janke et al. 2015; Monnier and Kinnard 2017; Anderson et al. 2018). Capps (1910) alluded to this idea by suggesting that movement started with refreezing and expansion of the glacier, then periglacial processes driven by snow and meltwater formed the interstitial ice. Others have acknowledged the fact that both permafrost and glacially derived rock glaciers can exist. Haeberli and Vonder Mühll (1996) argued that ice of glacial origin would disappear and be replaced by nonglacial ice through time. In the Front Range, Outcalt and Benedict (1965) suggested that rock glaciers resting on the cirque floor are ice-cored, and those that are valley-walled formed from interstitial ice or metamorphism of snow beneath rockfall. Humlum (2000) found that rock glaciers in 
Greenland were either talus-derived (periglacial) or glacial-derived (glaciers). He added that notwithstanding this debate, most scientists agree that rock glaciers are the result of a localized, high supply of talus in a permafrost environment. Therefore, it is likely that even if a rock glacier has a glacial ice-core, it is likely that periglacial processes still affect the rock glacier. Steig et al. (1998) presented evidence that both glacial and periglacial processes may be acting on the Galena Creek rock glacier. After plotting deuterium $(\delta \mathrm{D})$ versus oxygen $\left(\delta^{18} \mathrm{O}\right)$, the values fall close to the global meteoric water line. This suggests that the observed isotope stratigraphy largely reflects meltwater infiltration and refreezing rather than runoff derived from glacier ice.

Physical evidence of both permafrost and glacial ice-cores has been noted on several rock glaciers. On a rock glacier in the Hurricane Basin, San Juan Mountains, Brown (1925) found interstitial ice above the glacier core. Resistivity measurements indicate that rock glaciers in the Sainte-Anne cirque have ice-cores near their heads (glacial origin) and ice-cemented materials near the toe (periglacial origin) (Assier et al. 1996). On the Foscagno rock glacier in the Italian central Alps, a lower section of an ice-core between 4 and $7.65 \mathrm{~m}$ indicates firn ice, whereas the elongated vertical bubbles in the upper-core between 2.5 and $4 \mathrm{~m}$ suggest melting and refreezing (Guglielmin et al. 2004; Stenni et al. 2007). On the Arapaho rock glacier, extending from the rock glacier mid-section to the toe, drifting snow, rain, and snow meltwater pass downward through the rock debris, freeze, and become interstitial ice. However, the up-valley half consists of glacial ice (White 1971; 1975). In a later paper, White (1976) stated that all ice-core rock glaciers have a saucer-shaped depression between the rock glacier and the headwall, a longitudinal furrow, and pits. Ice-cemented rock glaciers are differentiated from this because they do not have these features but often have longitudinal ridges. In fact, White (1976) stated that lobate rock glaciers occurring on the south side of the Front Range, commonly contain interstitial ice, and move only about 1 to $6 \mathrm{~cm} \mathrm{yr}^{-1}$.

Rock glaciers are a transitional form regardless of the processes responsible for its formation (Figure 21) (Giardino and Vitek 1988a). The rock glacier will eventually cease to exist and will become a deposit in the rock record. A clear differentiation between process and form must exist. The term 'rock glacier' refers to a form, not a process. Rocks may be in a location before the form is created, and the finality of form as it is expressed in the geomorphic record. Too often, 
rates of movement are assigned to the form that neglects the processes responsible for producing the motion.

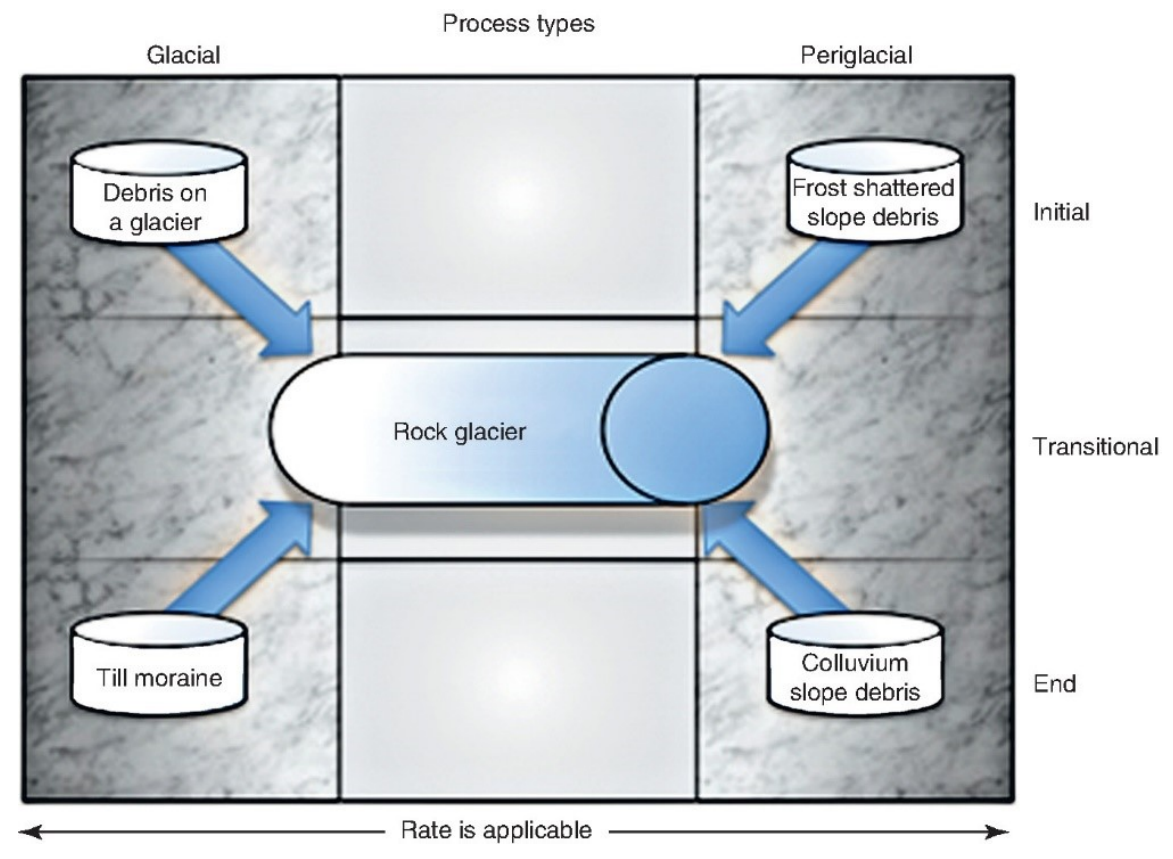

Figure 21 The alpine landscape continuum. Adapted from Giardino, J.R., Vitek, J. (1988a).

Recent research based on modelling and detailed remote sensing investigations (e.g. (Janke et al. 2015; Monnier and Kinnard 2017; Anderson et al. 2018) provide evidence that debris-covered glaciers can transition to rock glaciers, specifically with strong debris supply and inefficient sediment evacuation. The transition occurs specifically under persistently cold conditions. This is supported by recent work on the sedimentology of rock glaciers and related forms (Knight et al. 2018; Jones et al. 2019).

\subsection{Distribution and Climate}

Rock glaciers play an important role in the elevational distribution of landforms in glacial or periglacial environments (Caine 1984). Traditionally, rock glaciers were thought to exist in mainly low precipitation, continental climates where frost weathering is dominant and temperatures are cool enough to maintain ice (Barsch 1977; Haeberli 1983). In the Alps, Haeberli (1983) indicated rock glaciers exist in dry, continental climates at altitudes below the equilibrium line of glaciers but above the lower permafrost limit. Humlum (1998) and Janke 
(2007) found that rock glaciers and glaciers locations are driven by topoclimates that favor high talus production rates, not regional climates (Figure 22). Temperatures over the surface of a rock glacier appear to vary greatly over short distances. A horizontal distance of less than $535 \mathrm{~m}$ and a $100 \mathrm{~m}$ change in elevation exist among the sites. Temperatures do not decrease with higher elevation on the California rock glacier in Colorado. In fact, site 3 is the warmest in the winter but coldest in the summer (Figure 22). A $1.6^{\circ} \mathrm{C}$ mean difference exists during the winter, and a $2.8^{\circ} \mathrm{C}$ mean difference exists in the summer. Ground temperature measurements at different depth at Murtèl rock glacier show that temperatures near the surface exhibit high annual variability with temperatures up to $15^{\circ} \mathrm{C}$ in $0.25 \mathrm{~cm}$ depth but temperatures remain below $0^{\circ} \mathrm{C}$ in depths greater than about $5 \mathrm{~m}$ (Figure 23)

When the distribution is mapped, rock glaciers provide insight into Holocene and Pleistocene climates (Barsch and Updike 1971; Harris 1994; Steig et al. 1998; Frauenfelder and Kääb 2000; Moran et al. 2016). In Arizona and New Mexico, Barsch and Updike (1971) concluded that permafrost once extended as low as $2600 \mathrm{~m}$ during Wisconsin times. In the Tyrolean Alps, Kerschner (1985) found that permafrost extended from 500 to $600 \mathrm{~m}$ lower than today with a 3.0-4.0 ${ }^{\circ} \mathrm{C}$ lower MAAT. In the Swiss Alps, Frauenfelder and Kääb (2000) found that temperatures were once $3.0-4.0^{\circ} \mathrm{C}$ cooler, depressing the permafrost limit by $500-600 \mathrm{~m}$. In Greece, relict rock glacier slope deposits indicate that MAATs were $6.3-9{ }^{\circ} \mathrm{C}$ cooler, in agreement with paleoclimatic reconstructions (Hughes et al. 2003; 2006). In Colorado, Janke (2005c) found that the climate was once some $3.0-4.0^{\circ} \mathrm{C}$ cooler, with permafrost extending some 600-700 m lower than today.

Present climates affect rock glaciers by preserving or ablating an internal ice structure (Martin and Whalley 1987). Ordinarily, temperate alpine glaciers do not have clear ${ }^{18} \mathrm{O}$ and ${ }^{16} \mathrm{O}$ ratios for more than a few hundred years because of ablation, melting, and refreezing. However, a thick rock glacier debris cover slows these processes providing a longer interval of untapped 
climatic information (Barsch 1988; Haeberli et al. 1988; Haeberli 1990; Haeberli 1992; Clark et al. 1996; Steig et al. 1998; Konrad et al. 1999).

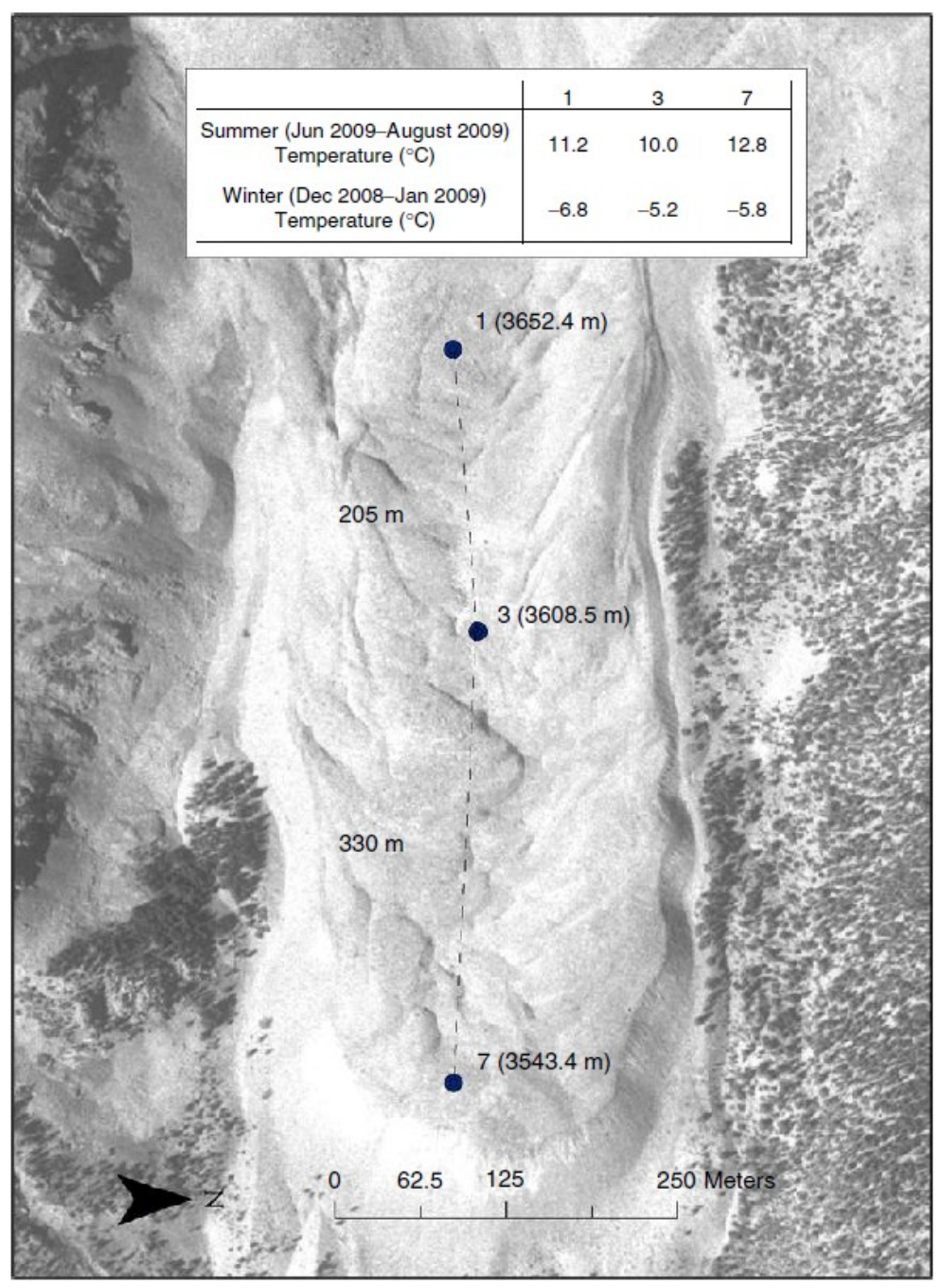

Figure 22 An example of the effects of microclimate on the California rock glacier, Huerfano valley, CO. Site 3 is the warmest in the winter but coldest in the summer which illustrates the 
effect that rock glacier topography and surrounding cirque wall geometry have on microclimate formation.

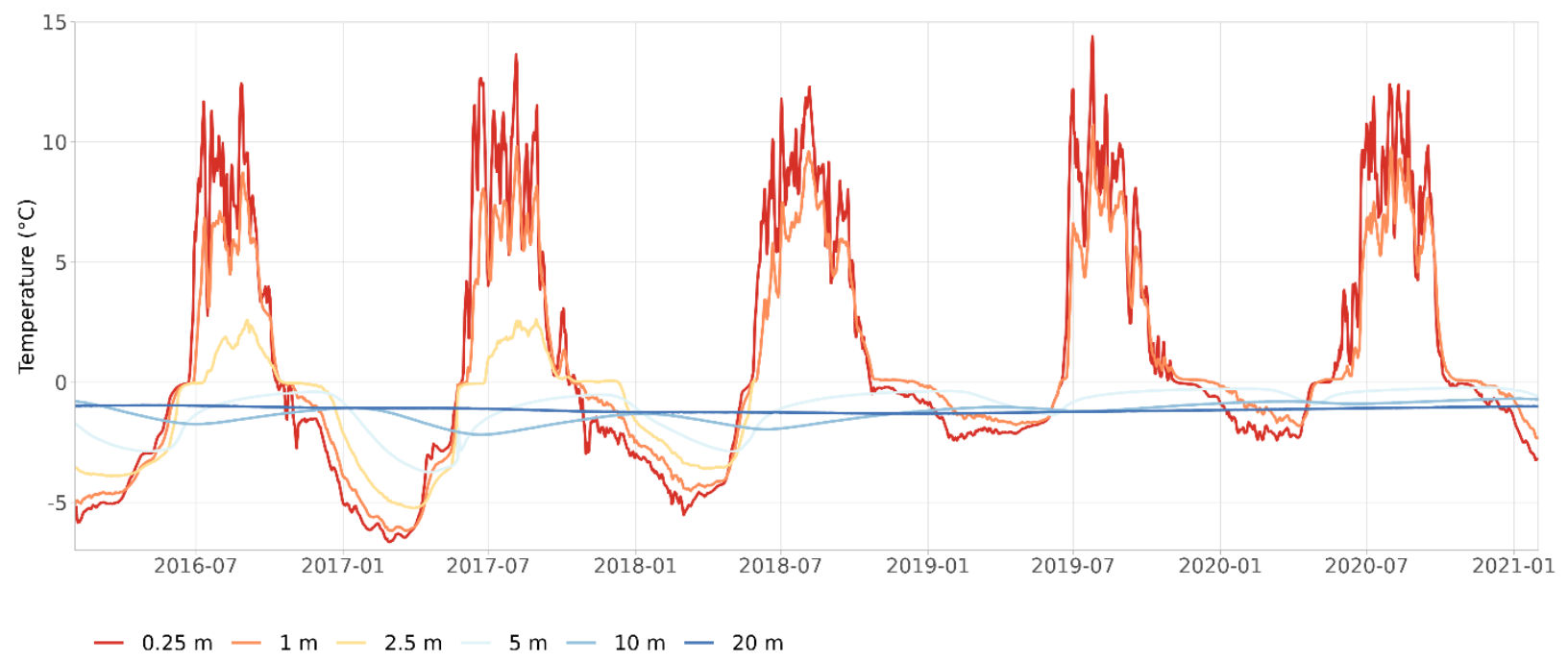

Figure 23 Temperature measurements in different depths from Murtèl rock glacier in the Swiss Alps from February 2016 until February 2021. Data source: Swiss Permafrost Monitoring Network (PERMOS).

\subsection{Rock Glacier Age}

The age of rock glaciers can be inferred from various techniques that include geomorphological climatic reconstructions, lichenometry, C-14 dating of organic remains trapped englacially, or weathering of surface clasts. Care must be taken when using these methods: it is important to determine whether the age refers to time of formation, time of rock deposition, age of the icecemented or ice-cored structure, or age of recent advance. Lichenometry has been used to date rock glacier surfaces based on lichen thallus size. Two different approaches, direct and indirect, are used. In the direct approach, growth rates are determined by monitoring individual thalli over several years, typically of abundant yellow green specimens (subgenus Rhizocarpon geographicum agg.). Growth rate curves can then be extrapolated to estimate age. The indirect approach uses surfaces of known ages to calibrate growth rates empirically. The accuracy of 
lichenometry dating is \pm 15 to $20 \%$ (Andrews and Miller 1972; Calkin and Ellis 1980; Bickerton and Matthews 1992; Solomina and Calkin 2003). Rates of lichen growth are affected by environmental factors such as snow, which slows growth or kills lichens, and talus, which disintegrates lichens. Even over short distances, $R$. geographicum growth rates can be quite different. This indicates that microclimates influence growth rates, which makes it difficult to extend growth rates over several decades (Bradwell and Armstrong 2007).

The relative age of a rock glacier can be determined by measuring the hardness of surface clasts using the Schmidt hammer test: weaker rocks exposed to more weathering are likely older (Haeberli et al. 2003). This method assumes rock hardness changes in a unidirectional manner; therefore, it may not correlate with other age indicators for a given locality (Burger et al. 1999). Radiocarbon dating of fossil wood remains encapsulated in rock glaciers can also provide an age estimate (Scapozza et al. 2010).

Most measurements indicate formation within the Holocene (last 10000 years), although the formation of some recent rock glaciers are believed to be associated with events during the Little Ice Age. On the Murtél-Corvatsch rock glacier in the Swiss Alps, subfossil stems of different bryophyte species were found at depths $6 \mathrm{~m}$ below the surface and about $3 \mathrm{~m}$ below the permafrost table, with ages ranging $800 \mathrm{BC}$ to $0 \mathrm{AD}$. The formation is believed to begin with the onset of the Holocene when glaciers were absent (Haeberli et al. 1999). Diameter of $R$. geographicum thalli revealed ages between 5000 and 6000 years which indicate the age of deposition of the boulders of Murtél rock glacier (Burga et al. 2004). Wohlfarth et al. (1994) suggested rock glaciers developed around 10700 BP in southwestern Switzerland. (Krainer et al. 2015) dated plant macrofossil in a core of Lazaun I rock glacier and found ages of $8960 \mathrm{cal} \mathrm{yr}$ BP at the bottom of the rock glacier in almost $24 \mathrm{~m}$ depth. Lewis and Hanvey (1993) believed that rock glaciers in South Africa were flowing some 21000 years BP.

In the Central Italian Alps, Calderoni et al. (1998) found peaty soils buried by rock glaciers that dated at 1120 years BP for active rock glaciers. Dates near the front of inactive rock glaciers were about 2700 years BP. C-14 dating of a buried paleosoil on the Foscagno rock glacier in the Italian central Alps indicates an age younger than 2200 \pm 60 years BP (Guglielmin et al. 2004). In the Schiantala Valley of the Maritime Alps, Italy, rock glaciers formed after a phase of glacier expansion occurring about $2550 \pm 50$ years BP. Calibrated C-14 ages of the tree remains found in 
a rock glacier front in the Russian Altai Mountains were $293 \pm 21$ years BP and $548 \pm 21$ years BP; given the time of emergence, the rock glacier developed between 3800 and 2600 and 550 years BP (Fukui et al. 2007). In the British Isles, rock glaciers likely developed during the Younger Dryas (Harrison et al. 2008). Age of plant remains from the basal sediments of a pond suggest that rock glaciers in northern Maine formed during the Younger Dryas (11 320 years BP). Ballantyne et al. (2009) identify relict rock glaciers in the Cairngorm Mountains of Scotland and date them between $12100 \pm 600$ years to $15400 \pm 800$ years. However, Jarman et al (2013) reinvestigated the identified landforms based on field surveys and aerial photo interpretation and question whether these lands forms are relict rock glaciers. Radiocarbon dates from the Lazaun I rock glacier in the southern Otztal Alps indicated an ice age at the base of nearly 10300 years old (Krainer et al. 2015).

At the Faeroe Island in the North Atlantic Ocean, a Younger Dryas age was suggested (Humlum 1998). Rock glaciers in Svalbard began forming about 3500 years BP (Andre 1994). Another estimate in Svalbard suggests that two tongue-shaped rock glaciers developed with the onset of the Holocene (Isaksen et al. 2000).

Organic materials removed from debris layers within Galena Creek rock glacier reveal a midHolocene or earlier age (Konrad et al. 1999). Lobate rock glaciers advanced in the Front Range 3340 years BP (Benedict 2005). Rhizocarpon geographicum on 48 lobes of 18 rock glaciers in the Elk Mountains and the Sawatch Range of central Colorado indicate ages of 3080 years BP (Refsnider and Brugger 2007). Hetu and Gray (2000) indicated a Younger Dryas to Early Holocene formation of lobate rock glaciers in the Chic-Choc Mountains in Quebec. Schmidt hammer measurements and weathering-rind thickness indicated that rock glaciers began forming around the Late Glacial or onset of the Holocene in the Japanese Alps (Aoyama 2005). Tropical Andes rock glaciers originated in the early Holocene (Francou et al. 1999; Fabre et al. 2001).

Rock glaciers in other parts of the world suggest that formation is associated with the Little Ice Age. Lichenometry suggests that rock glaciers in northern Iceland formed immediately after the Little Ice Age (Hamilton and Whalley 1995; Kirkbride and Dugmore 2001). Diameter of the largest lichens on the Mendel rock glacier in the Sierra Nevada, California indicate formation before the Little Ice Age ( $\approx 700$ years BP) (Konrad and Clark 1998). Humlum (1996) suggested that rock glaciers in Greenland formed during the Little Ice Age, about 550 years ago, when air 
temperatures were some 2 to $4{ }^{\circ} \mathrm{C}$ cooler than present (Humlum 1999). The Thabor-Cheyal Blanc rock glacier in the northern French Alps was not visible on ancient maps or pictures, so it must have formed during the last 200 years, during the end of Little Ice Age (Monnier 2007).

\subsection{Geophysical Methods Applied to Rock Glaciers}

Permafrost surface and subsurface features are highly variable; geophysical techniques have shown promise when detecting this heterogeneity (Kneisel et al. 2008). Since geophysical properties, such as electrical resistivity (and conductivity), permittivity, and seismic wave velocity, vary greatly from a phase change of water to ice, geophysical techniques have been used to investigate the subsurface properties of rock glaciers, map active layers, and monitor change (degradation or aggradation) of permafrost over time.

Direct current electromagnetic techniques, such as capacitive coupled electrical resistivity tomography (CCERT), measure permafrost distribution based on electrical resistivity or electrical conductivity. Conductive water is easily distinguished from nonconductive ice, although soil texture, porosity, water content, and salinity can alter measurements (Table 2). This is the most common method for determining properties of frozen ground. In a CCERT survey, resistivity data are obtained by pulling transmitters and receivers across the ground along a profile, which will result in a 2D dataset (Kneisel 2003; Hauck and Vonder Muhll 2003). A constant current is supplied by electrodes and the resulting voltage is measured at potential electrodes. From these values, resistivity can be calculated. Advantages of this method are its fast data acquisition, rapid deployment, and the fact that galvanic contact with the ground is not required, making it easier to obtain data on frozen ground.

Other electromagnetic techniques such as ground penetrating radar (GPR) are sensitive to change in dielectric permittivity, which shows a marked difference for frozen and unfrozen materials. Permittivity is affected by attenuation or the loss of signal intensity and is determined by the speed by which GPR waves move through different structures (Maurer and Hauck 2007). Structural change affects permittivity at contact zones where energy is reflected back to the surface or the wave propagates further into the ground. GPR uses two antennas, one to transmit short radio waves between 10 and $1000 \mathrm{MHz}$, and the other receive reflected energy. When 
antennas are moved across a survey line, a high-resolution image of subsurface ground properties can be obtained.

Additionally, gravimetry can be used to detect the presence and the thickness of ground ice. Data must be corrected for latitude, elevation, Earth tides, and topography of surrounding terrain. A model is then created to determine shape and density of body producing the gravity anomaly. The method has many limitations; intense modeling is required to correct the data, and resolution can be limited from the density variation of materials. Additional data in the form of gammagamma logs, boreholes, or refraction data are generally necessary to support data modeling. Problems may also arise when ice content increases continuously along a profile (Vonder Mühll and Klingelé 1994).

Radio echo soundings can also be used to get a rough estimate of the permafrost thickness and ice form; however, the depth of penetration is limited and unfrozen water causes absorption and scattering effects (King et al. 1987). Seismic refraction can be used to interpret the internal structure, but the method is limited because the seismic velocity contrasts between layers cannot always be detected because of layer thickness or rock type (Wagner 1996).

A combination of two or more geophysical techniques is generally beneficial because misinterpretation can result from using a single electromagnetic property (Table 2) (Schrott and Sass 2008). There are many limitations of these techniques when studying rock glaciers. The coarse surface of rock glaciers may require additional salt water-soaked sponges to achieve ground contact. CCERT allows mapping of spatial changes of permafrost bodies, but it does not represent stratigraphy well. On the other hand, GPR provides important stratigraphic information, but does not reveal changes in permafrost at reflectors. As a result, integration of these two data sources can provide valuable crosscheck information that validates interpretation.

Frozen ground and active layer thickness have been measured in both alpine and Arctic regions using electrical resistivity. Ice masses on rock glaciers and talus slopes have been assessed using electrical resistivity measurements (Isaksen et al. 2000; Hauck and Vonder Muhll 2003; Kneisel et al. 2008). P-wave velocities can be used to differentiate between active and inactive rock glaciers, whereas DC resistivities reflect structural differences such as icecemented or ice-rich rather than frozen and unfrozen differences (Ikeda 2006). Cui and Cheng (1988) detected two rock glacier layers using DC resistivity soundings near the Urumqi River, 
Tianshan Mountains. They observed a $1.5 \mathrm{~m}$ thick active layer associated with $2.5 \mathrm{k} \Omega$ soundings. The active layer is underlain by frozen sands and gravels with ice as indicated by soundings ranging from 32 to $37 \mathrm{k} \Omega$. Francou and Reynaud (1992) determined an active layer of 4 to $5 \mathrm{~m}$ thickness underlain by a 30 to $40 \mathrm{~m}$ thick $(800 \mathrm{k} \Omega)$ permafrost layer in Laurichard, French Alps using the geoelectrical sounding method. Geoelectrical tomographies revealed massive ice lenses at the apex and front of rock glaciers in the Central and Western Alps (Ribolini et al. 2010). In Svalbard, DC resistivity values indicate an ice-rich layer at 20 to $35 \mathrm{~m}$ lying on ice-saturated sediments (Isaksen et al. 2000). Electrical resistivity on rock glaciers in the Grizzly Creek region, southwest Yukon indicate no massive ice, even on rock glaciers that were once thought to have ice-cores (Evin et al. 1997). Geoelectrical soundings have been used to detect super-saturated sediment with ice that is tens of meters thick on the Portette rock glacier in Italy (Ribolini and Fabre 2007). Changes in the active layer revealed that the rock glacier is strongly influenced by latent heat, snowmelt infiltration, and air circulation. In the Andes of Argentina, geoelectric geophysical methods detected a wet layer underneath an $18.5 \mathrm{~m}$ frozen permafrost structure at the base of the El Paso rock glacier (Croce and Milana 2002). On the Murtèl rock glacier, DC resistivity tomography revealed a steeply dipping boundary near the toe, and high resistivities indicate high ice content (Hauck et al. 2003).

Degenhardt and Giardino (2003) used GPR to study the internal structure of a rock glacier in the San Juan Mountains, CO. Based on the GPR results, they found that the interior of the landform is composed of a layered permafrost matrix of ice, sediment, and ice lenses that comprise thicker depositional units formed through high-magnitude debris falls. Folds are observed in the uppermost layers, resembling the surface expression of ridges and furrows, which suggests that compressive stresses originating in the accumulation zone are transmitted downslope through the rock glacier. On two tongue-shaped rock glaciers in Svalbard, GPR revealed that longitudinal layers slant downward in relation to the rock glacier surface until an upward slant is reached near the toe. The layers are interpreted as snowdrifts that have been covered with debris from slides (Isaksen et al. 2000). GPR has also indicated layering structures on other rock glaciers that may correspond to mass movements of higher magnitude that covered snow patches or possibly the active layer above supersaturated permafrost (Berthling et al. 
2000). On a polar rock glacier on James Ross Island, Antarctica, longitudinal GPR profiles show upward dipping surfaces; transverse GPR profiles indicate a syncline structure inclined toward the central part of the rock glacier (Fukui et al. 2008). Radar measurements have even been transmitted through boreholes to identify cross-sections of ice-rich zones, underlying ice-free zones, and unconsolidated glacial sediments with air-filled voids (Musil et al. 2006). Monnier and Kinnard (2013) used GPR and boreholes to interpret the internal structure and composition of rock glaciers in Chile, which revealed degrading conditions.

Other geophysical techniques have also been used to investigate rock glaciers. Transient electromagnetic (TEM) identified a shear plane some 18-28 m deep on the Fireweed rock glacier, Alaska (Bucki et al. 2004). In Mullins Valley, Antarctica, seismic surveys indicated a thick glacier core that ranges from 90 to $95 \mathrm{~m}$ near the valley head (Shean et al. 2007). On the Murtél-Corvatsch rock glacier, Vonder Mühll and Klingelé (1994) found four layers according to drillings and gravimetric methods: an active layer ( $3 \mathrm{~m}$ ); massive ice ( 3 to $20 \mathrm{~m}$ thick); an icesilt-sand layer (20 to $30 \mathrm{~m}$ ); and a layer with ice-saturated blocks (30 to $50 \mathrm{~m}$ ) (Fig. 24D) Ideally, a combination of geophysical methods and other field methods should be used to interpret the internal structure of rock glaciers (Otto and Sass 2006). For example, Vonder Mühll et al. (2000) used a combination of a $58 \mathrm{~m}$ borehole and geophysical methods to determine the internal structure of the Murtél-Corvatsch rock glacier, which allowed mapping of the permafrost table and lateral extent of a deep shear horizon. Later (Maurer and Hauck 2007) applied 
geoelectric, seismic and georadar surveys at the same rock glacier which facilitated the interpretation of the internal structure (Fig. 24).

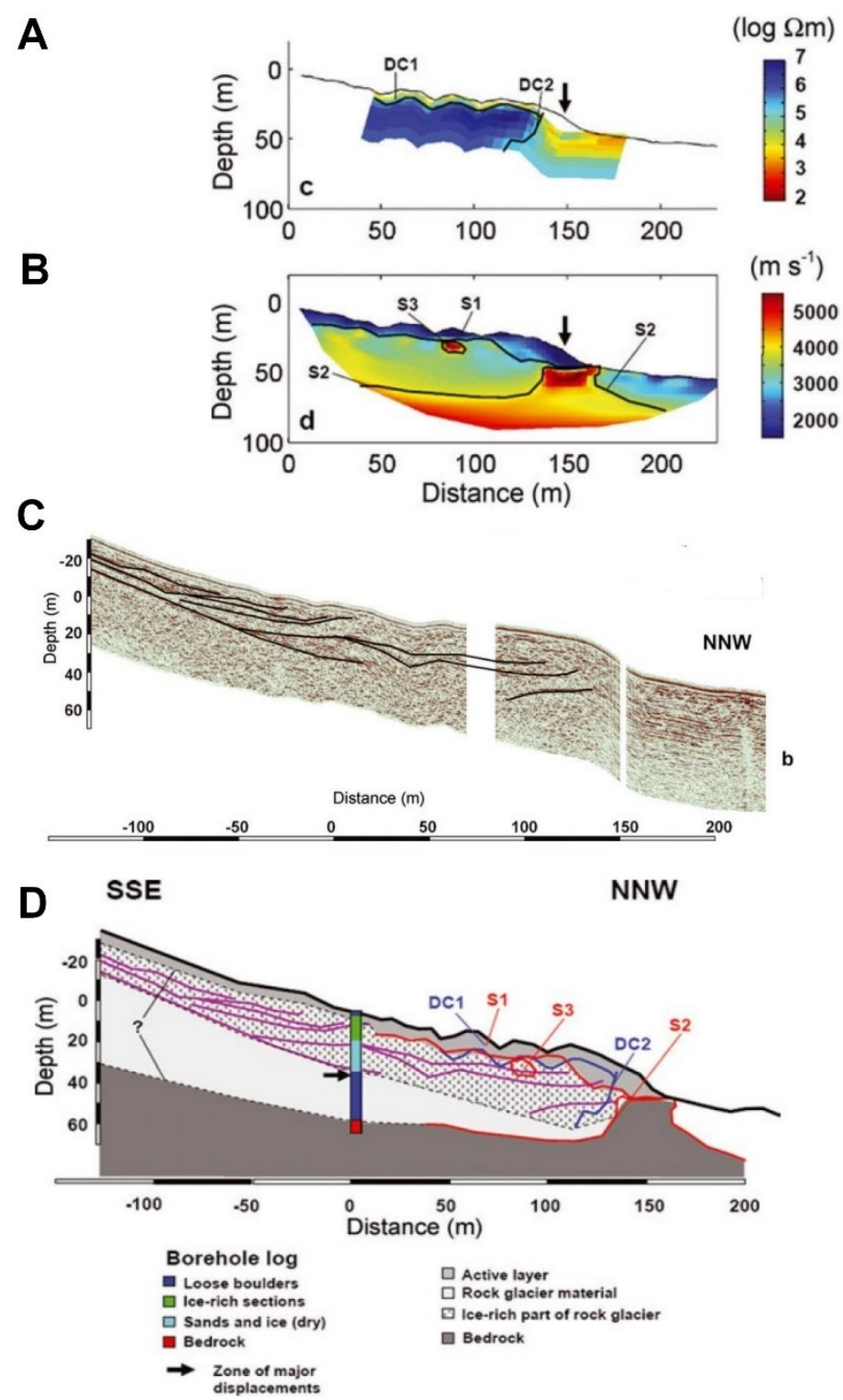

Figure 24 Results from the (A) geoelectric, (B) seismic and (C) georadar surveys conducted on the Murtèl rock glacier. Interpretations superimposed on the tomograms of (a) and (b), respectively. (D) Integrated interpretation of boundaries observed. The borehole log is also displayed. DC1 and S1 denote the active layer, DC2 is the boundary between frozen and 
unfrozen material, S2 is the bedrock interface and S3 is probably a huge boulder, Source: (Maurer and Hauck 2007).

\subsection{Characteristics of Rock Glacier Flow and Surface Elevation Changes}

Rates of surface motion rock glaciers vary from a few centimeters to several meters per year. According to Haeberli et al. (2006), the following variables must be taken into consideration to understand a rock glacier flow/creep: (1) rock weathering, snow avalanches, rockfall, and associated rock sizes; (2) freezing processes and ice formation in a combination of fine and coarse-grained rocks; (3) the thermohydromechanics of creep and failure processes in frozen debris; (4) kinematics of nonisotropic, heterogeneous and layered permafrost; and (5) down valley spatial and temporal variation in motion as evident in ridges and furrows. The surface displacement can either be measured using field surveying techniques such as repeated Global Navigation Satellite System (GNSS) measurements or triangulation, near-range remote sensing such as terrestrial laser scanning or drone survey or air- and spaceborne remote

sensing using feature tracking or DInSAR techniques (Table 3). Manual photogrammetric point- 
to-point methods with stereocomparators or analog plotters were first used to measure the horizontal and vertical displacement of large surficial rocks (Figures 25 and 26).

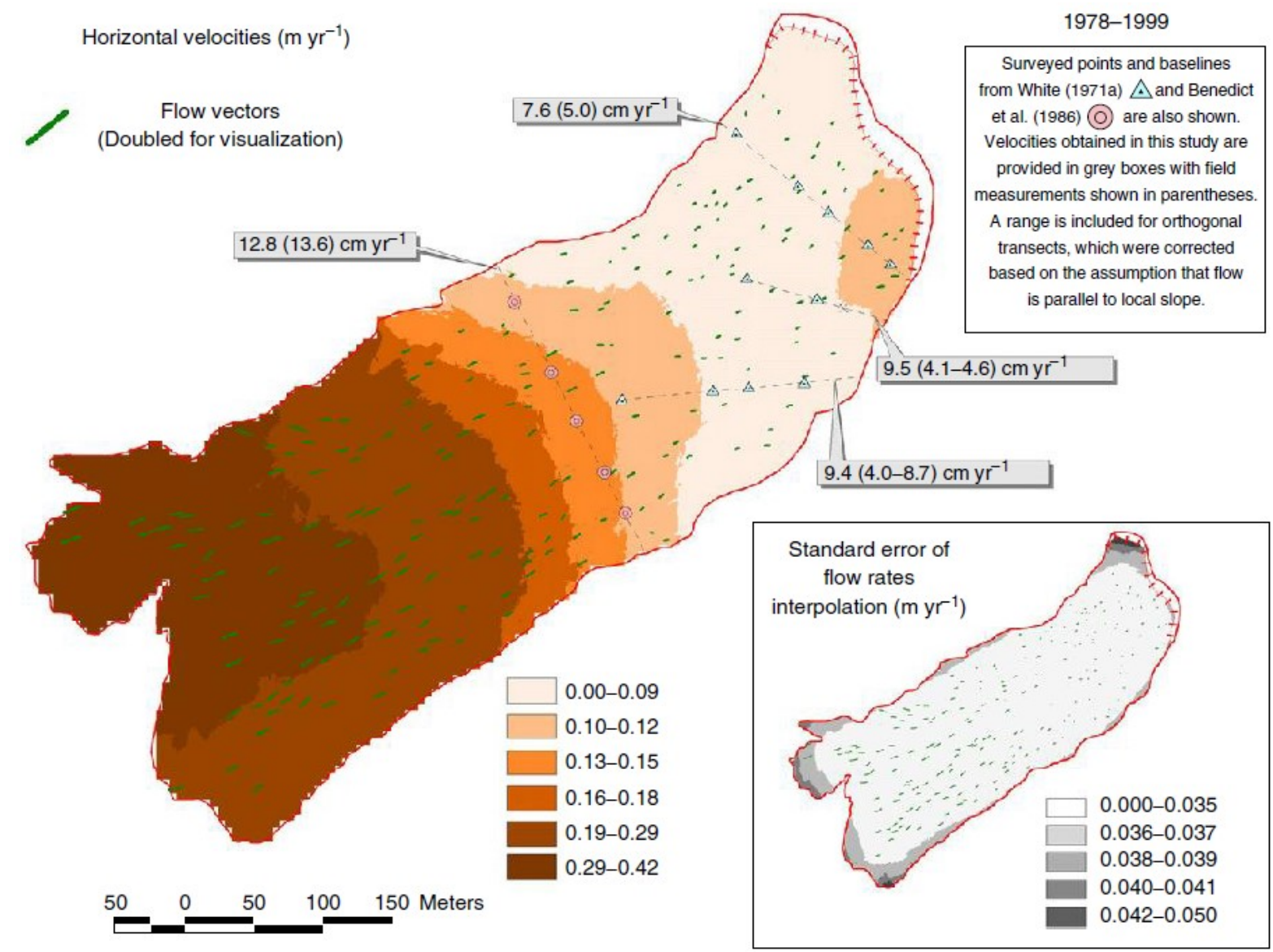

Figure 25 Photogrammetrically derived flow vectors and field measurements of flow on the Arapaho rock glacier in Colorado (Janke 2016). 


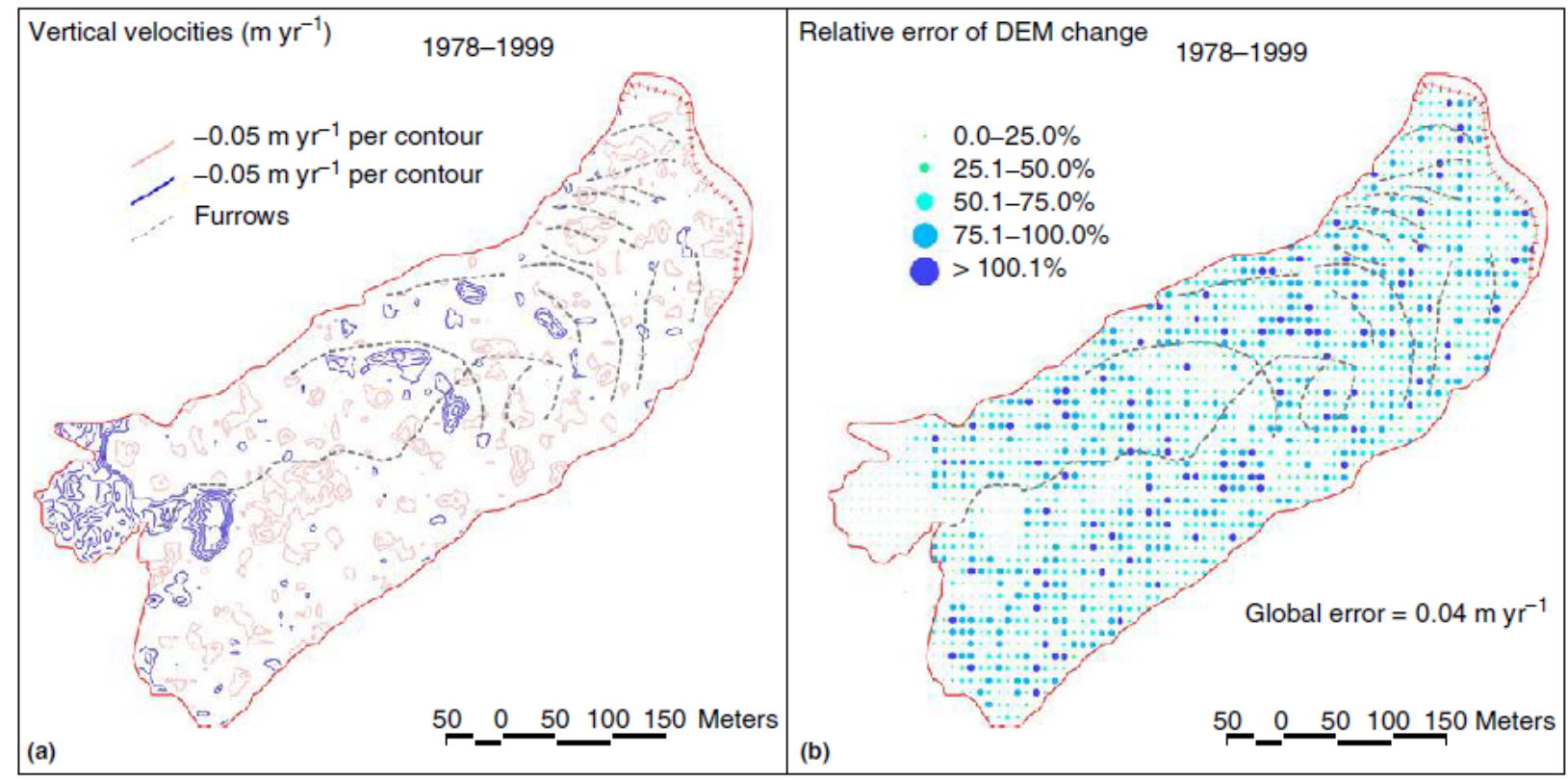

Figure 25 Vertical change on the Arapaho rock glacier (a) and relative error of measurements (b) (Janke 2016).

Advances both in remote sensing data and methods allow the surface displacements to be measured with subpixel accuracy, allowing even displacements in the centimeter range to be detected over the entire rock glacier surface (Figures 27 and 28) 


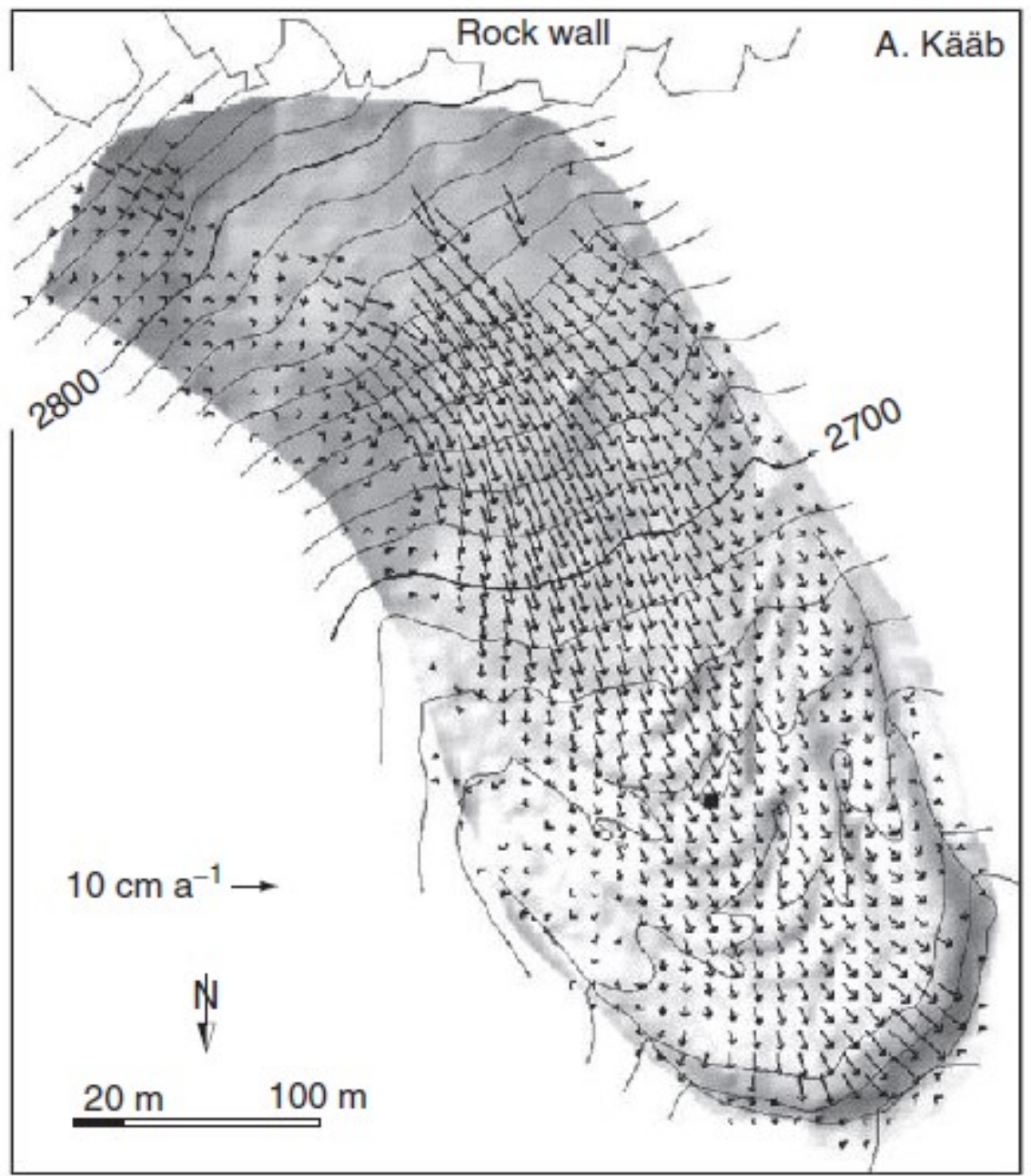

Figure 27 Horizontal displacements 1987 - 1996 on the Murtél rock glacier, Upper Engadine, Switzerland. Source: (Kääb et al. 1998) 

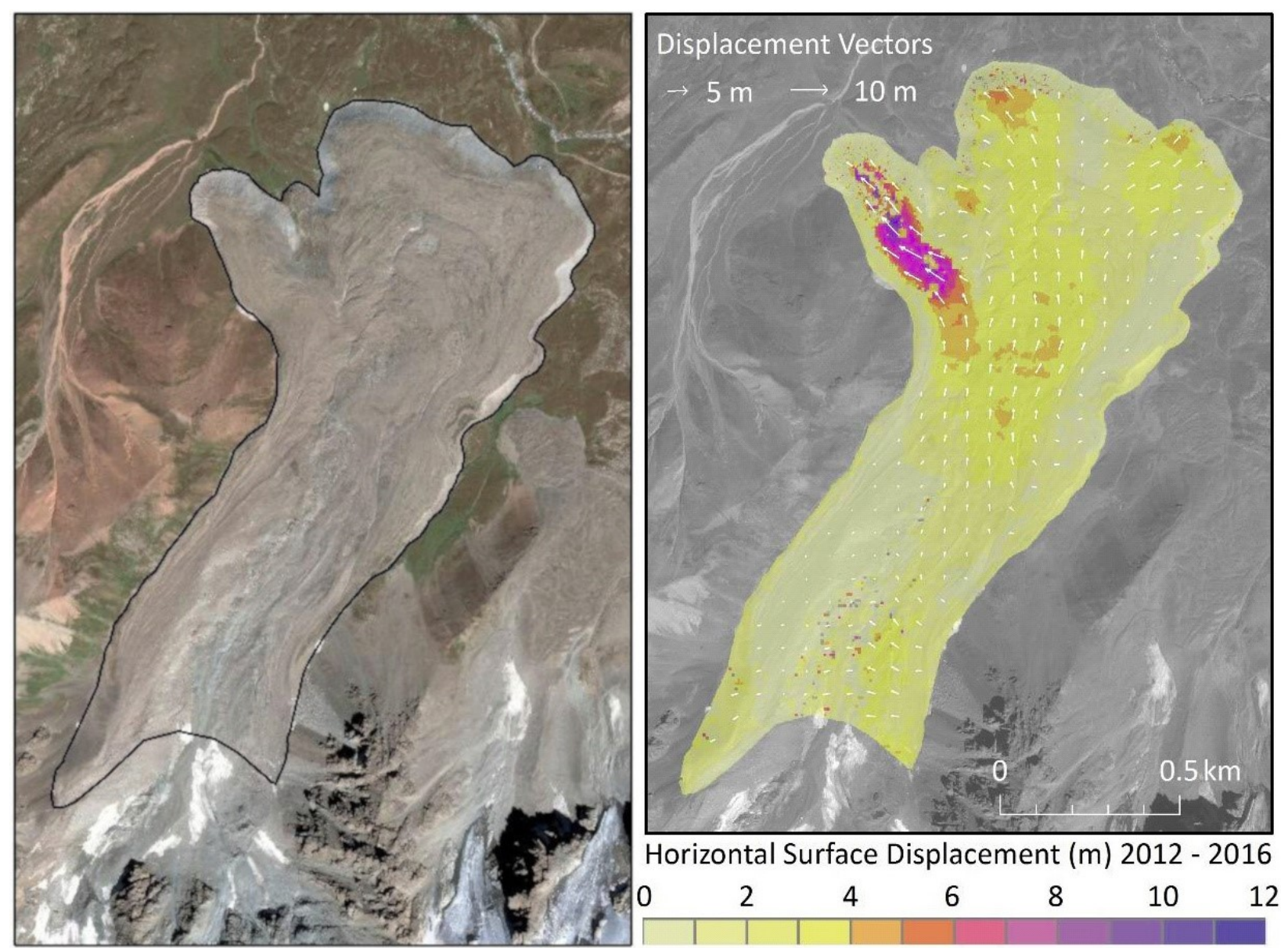

Figure 28 Morreiny rock glacier, Northern Tien Shan; Left: 2012 GeoEye image, Right: Surface displacements measured using the feature tracking method and high-resolution 2012 GeoEye and 2016 Pléiades data. Figure generated by A. Strel and T. Bolch. Pleiades data C 2016 CNES and Airbus Defence and Space.

Remote sensing and GNSS techniques show much promise to detect subtle seasonal and long-term rates of flow at unprecedented spatial precision and accuracy (Strozzi et al. 2004). In the Beacon Valley, Antarctica, a precision of $\mathrm{mm} \mathrm{yr}^{-1}$ can be obtained using synthetic aperture radar (SAR) data; peak velocities were about $4 \mathrm{~cm} \mathrm{yr}^{-1}$ on rock glaciers (Rignot et al. 2002). Differential SAR interferometry (D-InSAR) was used to detect an average displacement of 0.6 $\mathrm{cm}$ per 35 days on some rock glaciers. The head of the rock glacier is deforming at $1.8 \mathrm{~cm}$ per 35 days, and the toe is moving at about $1.0 \mathrm{~cm}$ per 35 days (Kenyi and Kaufmann 2003). (Liu et al. 
2013) found surface displacements between 14 and $87 \mathrm{~cm} / \mathrm{a}$ in the Sierra Nevada, USA, based on late summer ALOS Palsar data.

Terrestrial laserscanning (LiDAR) has been used to monitor the front of Hinteres Langtalkar rock glacier from 2000 to 2008 in the Austrian Alps. A positive surface elevation change over the entire analysis period was evident, but decreasing surface lifting became apparent over the last 3 years (Avian et al. 2009). On the Besiberris rock glacier in Spain, a 10-year (1993-2003) geodetic survey revealed that velocities increase from the head to the toe; velocities are greatest in the interior or axis of the rock glacier, and vertical lowering has also been detected (Chueca and Julian 2005). As cameras and sensors continue to improve, high-resolution stereo cameras (e.g., HRSC-A) or stereo satellite images (e.g., Pléiades, GeoEye, Worldview) that records digital multispectral and panchromatic stereo bands could be used to construct high-resolution DEMs and detect change (Otto et al. 2007; Bolch et al. 2019). The best accuracy can be achieved with a UAV/Drone survey or terrestrial laser scanning (Abermann et al. 2010; Vivero and Lambiel 2019). Time series can be extended back using historical aerial images or highresolution reconnaissance satellite imagery (Bolch and Strel 2018; Bolch et al. 2019). The surface elevation changes of active rock glaciers are typically characterized by surface lowering below the rooting zone, variable changes in the middle part (especially due to the displacement 
of the ridges and furrows, and a surface elevation gain at the front due to the forward movement of the rock glacier (e.g. (Abermann et al. 2010; Müller et al. 2016), Figures. 29, 30)

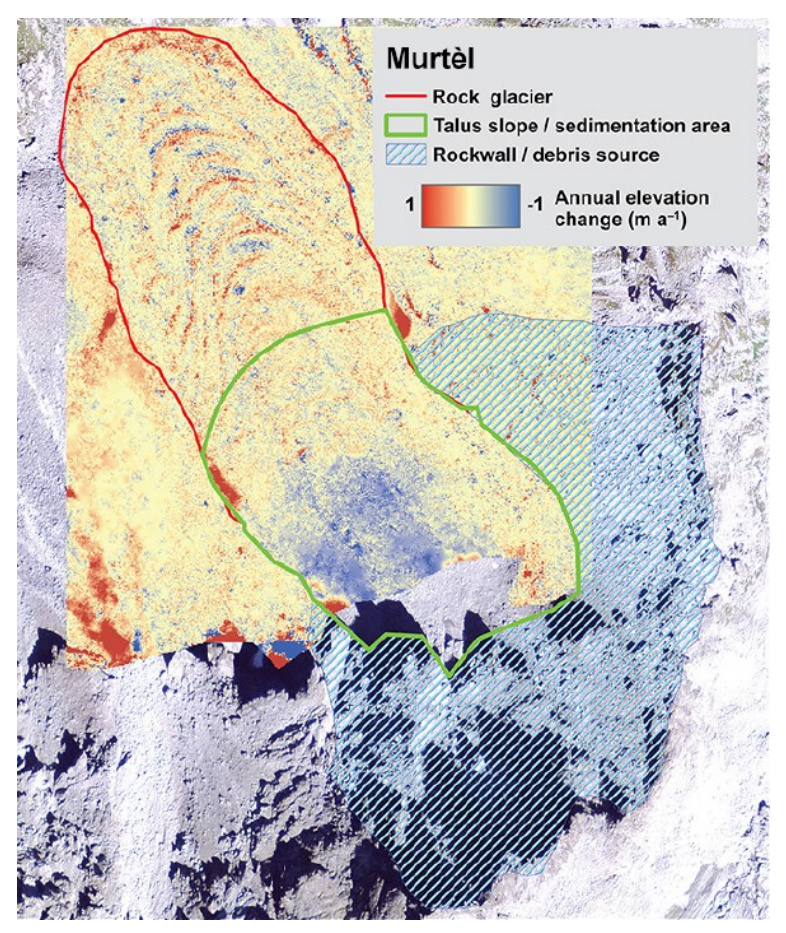

Figure 29 Surface elevation change of Murtel rock glacier (Swiss Alps) between 1997 and 2006 based on stereo aerial images (Müller et al. 2016). 


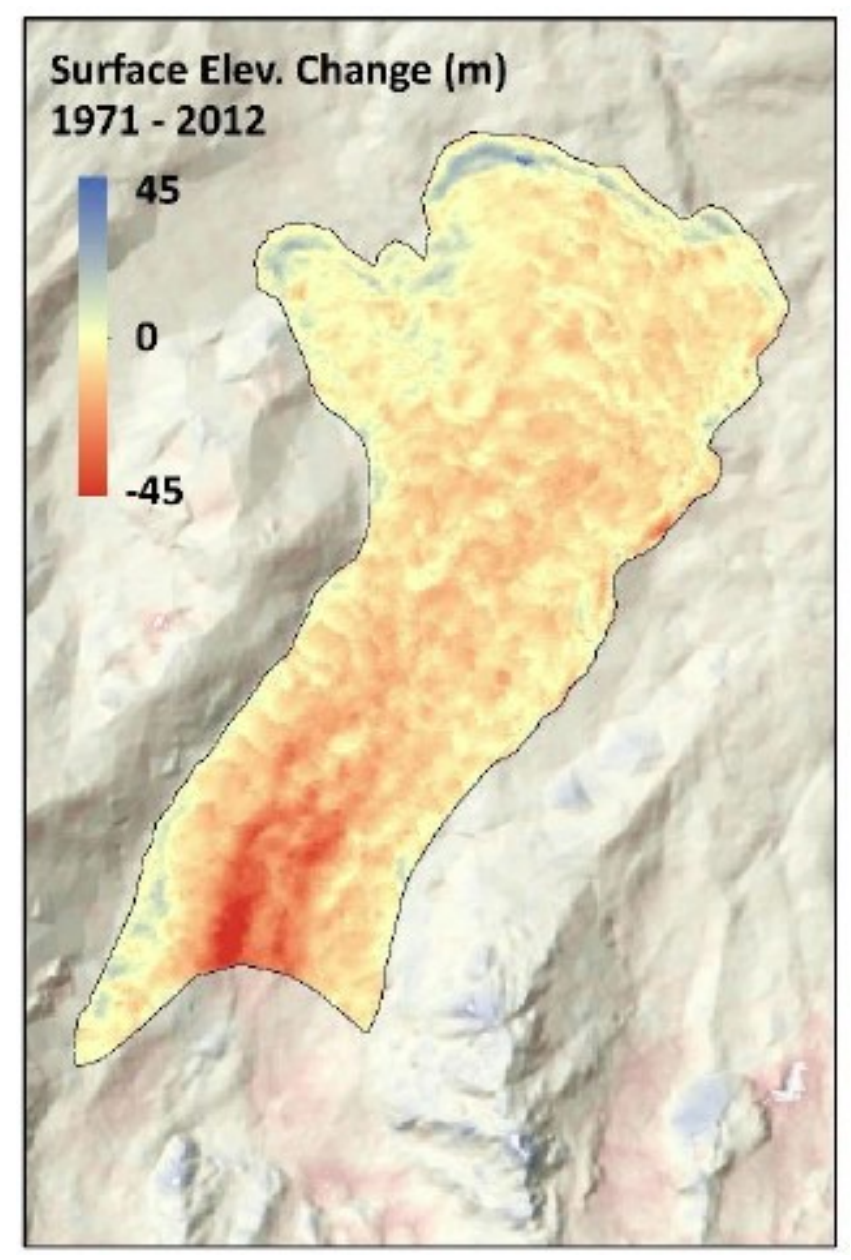

Figure 30 Surface elevation change of Morainny rock glacier in Ile Alatau, Tien Shan, Kazakhstan between 1971 and 2012 based on stereo Corona and GeoEye images. Source: A. Strel, T. Bolch.

MAAT has the strongest correlation with mean annual velocity, but it is also important to examine the time scale of the response to climate change (Janke and Frauenfeldeler 2008; Scapozza et al. 2014). Warm ice can deform more quickly than cold ice, or meltwater can act as a lubricant and reduce friction between internal shear planes (Bucki and Echelmeyer 2004; Jansen and Hergarten 2006; Krainer and Mostler,2006; Ikeda et al. 2008). Recent investigations showed that the rates of flow are mainly impacted by meltwater (Bodin et al. 2009; Cicoira et al. 2019). GNSS real-time kinematics (RTK) provides precise data to detect horizontal and vertical motion to simulate $3 \mathrm{D}$ rotational movements of boulders over short time scales (Lambiel and 
Delaloye 2004). Continuous measurements at selected rock glaciers in the Swiss Alps showed similar intra-annual variability with rapid acceleration in spring and a smooth decreasing velocity in late autumn. Short-term velocity peaks can be related to strong water input from snowmelt or precipitation (Wirz et al. 2016; Buchli et al. 2018; Cicoira et al. 2019).

The Büz North rock glacier on the lower limit of the permafrost belt in the Swiss Alps deforms rapidly during snowmelt periods but decelerates below a dry snow cover during the winter (Ikeda et al. 2008). At the Ölgrube rock glacier, flow velocities vary seasonally with higher rates during the melt season as evident by several springs near the front slope of the rock glacier (Krainer and Mostler 2006).

Deformation in boreholes revealed distinct shear zones where horizontal and vertical differential movements are concentrated (Arenson et al. 2002) (Figure 31). Musil et al. (2002) found that shallow seismic profiles and four boreholes drilled up to $70 \mathrm{~m}$ indicate two distinct velocity regimes superimposed on a general increase in velocity with depth. Conveyor belt advance mechanisms have also been observed on the Gruben and Suvretta rock glaciers. The toe of Suvretta rock glacier has a linear velocity profile over the entire thickness, whereas the 
Gruben rock glacier has horizontal mass transport concentrated in a 5-10 m thick surface layer (Kääb and Reichmuth 2005).
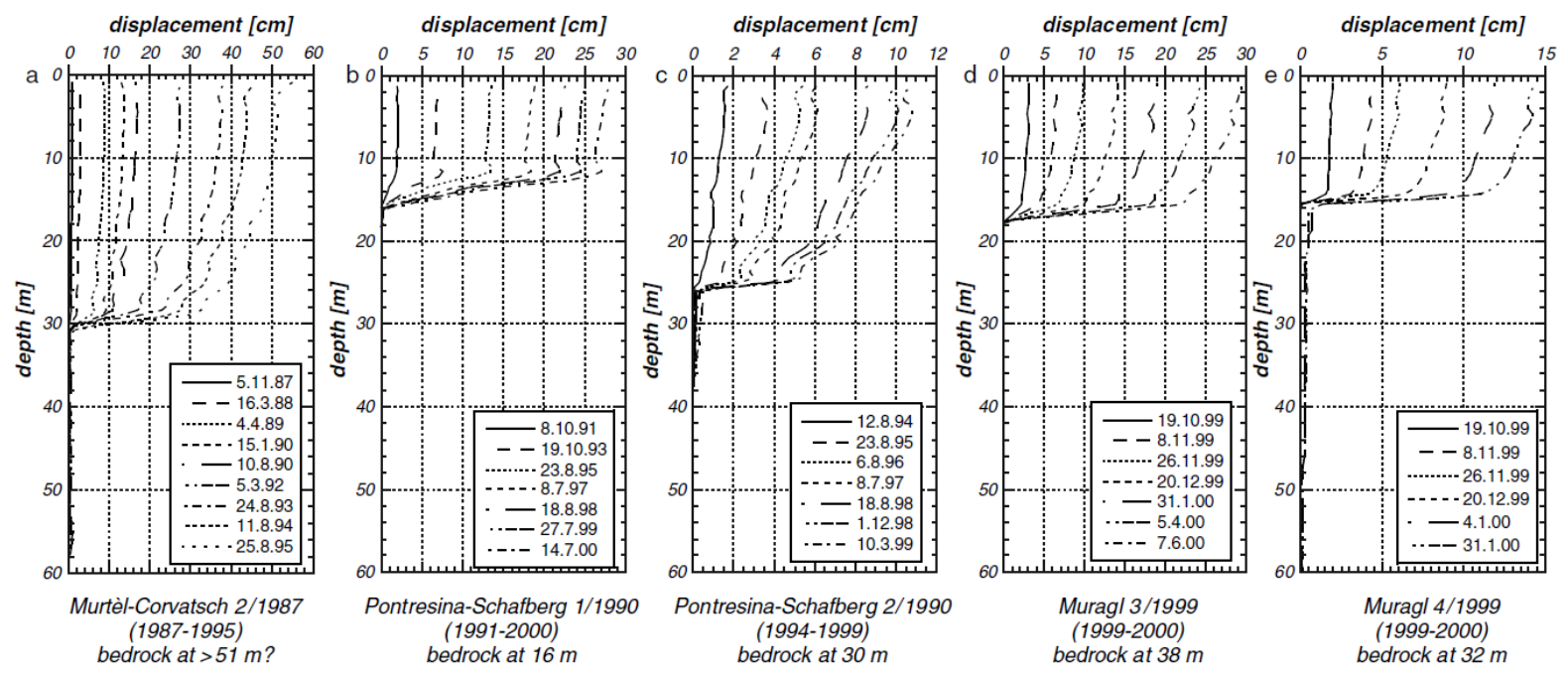

Figure 31 Displacement measurements at selected boreholes in rock glaciers in the Swiss Alps. All measurements show a distinct shear horizon (Arenson et al. 2002).

Dendrochronology can provide information on long-term changes of the rock glacier front (Shroder and Giardino 1987). On the Hilda rock glacier, overridden trees indicate an advancement rate of $1.6 \mathrm{~cm} \mathrm{yr}^{-1}$ since the late 1790s (Bachrach et al. 2004; Carter et al. 1999). Giardino et al. (1984) studied the motion of a rock glacier for more than 400-years based on the tree rings. Shroder and Giardino (1987) studied rock glaciers on Table Cliff Plateau, Utah and Mt. Mestas, CO, and dated the movement of these two rock glaciers for two centuries.

\subsection{Hydrology}

Water movement through rock glaciers is controlled by local weather, the seasons, the thermal properties of the debris layer, and the physical mechanisms that control meltwater (Geiger et al. 2014; Pourrier et al. 2014; Harrington et al. 2018). Although the general discharge pattern is the same, the average yearly mean specific discharge from active rock glaciers is significantly lower than glaciers (Krainer and Mostler 2002). Giardino et al. (1992) described the interior of rock glacier as similar to an aquifer. The water input to the rock glacier can come directly from precipitation, melt from snow patches on the rock glacier surface, runoff from adjacent slopes, or 
from groundwater. Rock glaciers provide a continuous meltwater supply during the summer months, analogous to an alpine aquifer (Burger et al. 1999). Rock glacier melt is of specific importance in arid regions with no or low glacier coverage (Rangecroft et al. 2013). Water can flow near the surface, above the active layer, or can flow in the deep subsurface beneath permafrost (Figure 32). The permafrost layer acts as an impermeable boundary between these two layers. During late summer/early fall, falling temperatures create freezing fronts that move upward from the perennial permafrost and downward from the rock glacier surface, squeezing together the remaining water in the central portion of the active layer (Giardino et al. 1992; Burger et al. 1999).

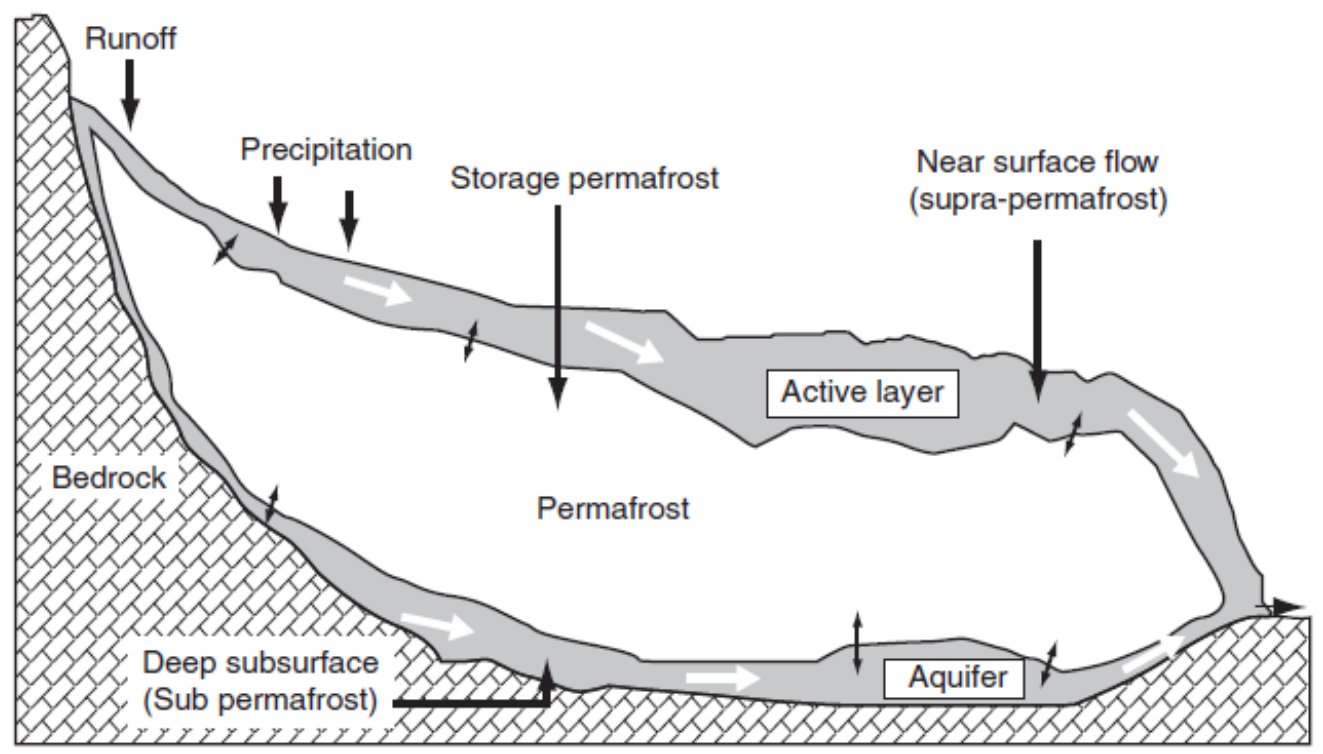

Figure 32 A hypothetical model of water flow through a rock glacier (Giardino, et al. 1992).

In addition to the aforementioned inputs, discharged water can also come from melting icerich permafrost or an internal ice structure. Baltensperger et al. (1990) suggested that a $\mathrm{pH}>6$ indicates groundwater rather than meteoric water, according to data from the Múrtel rock glacier. Water temperature is typically below $1{ }^{\circ} \mathrm{C}$ during the melt season. Electrical conductivity is low during high discharge and high during cold weather (Krainer and Mostler 2002).

In the Andes or other areas where precipitation is scarce, rock glaciers appear to be a more significant source of water storage compared to temperate glaciers (Fabre et al. 2001; Azocar 
and Brenning 2010). In the Bolivian and Argentinean Andes, rock glaciers act as a water storage unit in a low precipitation areas (Francou et al. 1999; Perucca and Angillieri 2008; Rangecroft et al. 2015). Rock glaciers are estimated to have $0.3 \mathrm{~km}^{3}$ of stored water per $1000 \mathrm{~km}^{2}$ in the mountainous area in the Andes of Santiago, Chile - an order of magnitude higher than the Alps (Brenning 2005). In Northern Tien Shan in Central Asia, rock glaciers store a significant amount of ice which are an important water source during summer (Bolch and Marchenko 2009). Also, in many other mountain regions of the globe, rock glaciers contain large ice reserves (Jones et al. 2019). Rock glaciers could represent a significant water source in a future warmer climate, such as in the Sierra Nevada or other mountain ranges (Millar and Westfall 2008; Harrison et al. 2021).

Discharge from rock glaciers can alter the geochemistry of alpine streams, rivers, and lakes by altering temperature, $\mathrm{pH}$, major ions, trace elements, diatoms, dissolved organic matter, bacterial richness, etc. (Thies et al 2013; Ilyashuk et al. 2014; Fegel et al. 2016; Colombo et al. 2018). Williams et al. (2007) found that 7 Rocky Mountain rock glaciers emit higher nitrate concentrations $\left(69 \mu\right.$ moles $\left.1^{-1}\right)$ compared to snow $\left(7 \mu\right.$ moles $\left.1^{-1}\right)$ and rain $\left(25 \mu\right.$ moles $\left.1^{-1}\right)$. In the Green Lakes Valley, Colorado, nitrate concentrations from rock glaciers increased seasonally, reaching a maximum in October - the highest concentration in the valley. Seasonal variation has also been observed for other geochemical solutes (Williams et al. 2006). At Green Lakes 5 rock glacier, $\mathrm{Mg}^{2+}$ concentrations increased to more than $4000 \mu \mathrm{eql}^{-1}$ in September; $\mathrm{Ca}^{2+}$ was greater than $4000 \mu \mathrm{eql}^{-1}$; and $\mathrm{SO}_{4}{ }^{2-}$ reached $7000 \mu \mathrm{eql}^{-1}$. The concentrations were significantly higher than those observed from June to August. At the Rasass See in the European Alps, electrical conductivity has risen 18 -fold and nickel concentrations have exceeded drinking water limits by an order of magnitude from increased melt from rock glaciers (Thies et al. 2007). In the Loch Vale Watershed in Colorado, it is believed that thicker active layers of rock glaciers are increasing stream nitrate concentrations, which are 50\% greater since 2000 compared to the 1991-99 period (Baron et al. 2009). Nitrate, calcium, and sulfate are also higher in the rock glacier meltwater from 2000 to 2006. In the Andes of Argentina, tropical glaciers deliver a $\mathrm{HCO}_{3}{ }^{-}$and $\mathrm{Ca}^{2+}$ solution, whereas rock glaciers emit an $\mathrm{SO}_{4}{ }^{2-}, \mathrm{HCO}_{3}{ }^{-}$, and $\mathrm{Ca}^{2+}$ solution (Lecomte et al. 2008). Gypsum dissolution through sulfide oxidation is the most important 
geochemical mechanism delivering the oxides. Silicate weathering is more important when meltwater has a longer residence time, and calcite and gypsum dissolution is more noticeable in recently melted water (Lecomte et al. 2008).

\subsection{Topoclimatic Conditions}

Remote sensing has improved our understanding of rock glacier distribution, their characteristics, topoclimates that facilitate rock glacier formation. Topoclimates have been shown to be important for rock glacier formation, more so, compared to regional climates, even where rates of insolation are high.(Vitek and Giardino 1987; Brenning and Trombotto 2006). In the subtropical Andes, local and catchment slope and potential incoming solar radiation characterize the locations of rock glaciers (Bolch and Schröder 2001; Brenning and Azócar 2010). High elevations, southern or eastern-facing aspects, areas with low solar radiation, and slopes less than $20^{\circ}$ favor rock glacier occurrence in the Andes of Argentina (Angillieri 2010).

In Greenland, dry, continental areas are ideal for rock glacier occurrence. In the Southern Alps, New Zealand, ice-rich forms of glacial origin exist in the humid north, and debris-rich forms of periglacial origin exist in the more arid south (Brazier et al. 1998). In Greenland, active rock glaciers tend to plot close to ELA for modern glaciers. Rock glaciers, however, require high retreat and weathering rates in the source area (Humlum 2000). Ideal sites also favor the high production of talus in the Southern Alps (Kirkbride and Brazier, 1995). Surface snow near the head of the rock glacier freezes and acts as a slideway to deliver rocks detached from the headwall (Pancza 1998). In Trollaskagi, northern Iceland, rock glaciers form at the foot of steep northern slopes where snow accumulates from avalanches and drifting from southerly winds (Farbrot et al. 2007). Steady-state rockfall accumulation, however, may not be sufficient to initiate rock glacier formation; a rock-slope failure is needed to supply enough debris (Sandeman and Ballantyne 1996). In Nanga Parbat Himalaya, Pakistan, inefficient sediment transfer processes, mainly from slow ice movement, allow rock glaciers to form (Shroder et al. 2000). The size of weathered rocks supplied can also influence the ability to support a matrix used to 
induce creep; pebbly rock glaciers that can support matrix debris have a greater length compared to bouldery rock glaciers (Matsuoka et al. 2005).

Coarse surface layers act as a thermal filter that protects the frozen rock glacier core when snow cover is absent or thin (Humlum 1997). Ingelrest et al. (2010) deployed a monitoring system on a rock glacier in Switzerland and discovered microclimatic characteristics that lead to cold air release. Advective air movement within blocky debris has much less influence on the thermal regime than the vertical displacement of air masses (Hanson and Hoelzle 2004).

GIS has been used to examine the distribution and characterize topoclimatic conditions of rock glaciers. In the Adam-Presanella Massif of the Italian Alps, active rock glaciers lie below the $-1{ }^{\circ} \mathrm{C}$ MAAT isotherm, suggesting that rock glaciers are not in equilibrium with the current climate, or rock glaciers may have extended to lower elevations (Baroni et al. 2004). Bolch and Gorbunov (2014) modelled permafrost distribution based on field evidence, temperature, and solar radiation in Northern Tien Shan and showed that the lower limit of many large rock glaciers is located lower than the zone where permafrost is likely. Headwall height, size of the contributing area, and slope explained the occurrence of rock glaciers. In the Lemhi Range in central Idaho, rock glacier locations are determined by topographic shading, lithology, relief, aspect, and elevation (Johnson et al. 2007). In the San Juan Mountains of Colorado, nonlinear factors of slopes, contributing area slope, local curvature, and contributing area size exhibit topographic controls on rock glacier occurrence (Brenning et al. 2007). In the Front Range of Colorado, tongue-shaped rock glaciers occur at higher elevations, northern aspects, and have gentler slopes compared to lobate forms. Active tongue-shaped rock glaciers had similar topographic variables compared to temperate glaciers, but lobate forms showed a significant difference (Janke 2007). In the Sierra Nevada, CA, rock glaciers exist at mainly on NNW to NNE aspects at a range of elevations from 2225 to $3932 \mathrm{~m}$ (Millar and Westfall 2008). In the Swiss Alps, Frauenfelder et al. (2008) simulated spatio-temporal rock glacier processes at a regional scale and found that the model is highly dependent on input parameters, illustrating the importance of local variables on the distribution of rock glaciers.

Because rock glaciers contain ice, they have been used to represent regional permafrost distribution. In the eastern Himalayas, rock glacier distribution indicates discontinuous permafrost at $4800 \mathrm{~m}$ on the north facing slope and at $5300 \mathrm{~m}$ on south to east facing slopes. 
These estimates are considerably higher than the western Himalayas (Ishikawa et al. 2001). (Schmid et al. 2015) assessed permafrost distribution modelling using rock glacier occurrence in the whole Hindu-Kush-Himalaya region. Imhof (1996) used altitude, slope, aspect, and ground cover types associated with permafrost to develop a PERM model. Rock glacier locations across the Bernese Alps showed a good correlation with the PERM results. A regional map of permafrost (Iceland) based on meteorological data was validated based on rock glacier inventories (Etzelmüller et al. 2007). Rock glaciers show a good correlation with regional permafrost models in Switzerland, classifying about $70 \%$ of active rock glaciers correctly (Nyenhuis et al. 2005). Janke (2005b) used DEM variables (elevation and aspect) from rock glaciers that contain ice and land cover data to estimate permafrost occurrence in the Front Range of Colorado. Azocar et al. (2017) utilized rock glacier activity status and temperature data to model distribution in the semi-arid Chilean Andes. Mercer et al. (2017) developed a permafrost favorability index for the French Alps based on a rock glacier inventory. A combination of geophysical, remote sensing, and field detection methods are best to verify the presence of ice-rich permafrost in glacier forefields, rock glaciers, or other kinds of ice-debris landforms (Kneisel and Kääb 2007; Bolch et al. 2019). Permafrost mapping could be improved by monitoring flow through photogrammetric techniques to verify motion that is driven by ice (Strozzi et al. 2004; Kääb and Kneisel 2006; Roer and Nyenhuis 2007).

\subsection{Response of Rock Glaciers to Climate Change}

The climatic response of rock glaciers is different compared to glaciers. Their typical bouldery layer (1-3 m thick in some instances) acts as an insulator and protects internal ice core or ice debris mixture, and smooths their response to climate (Barsch 1996; Konrad et al.,1999). This debris filters short-term climate anomalies; therefore, a strong climatic signal must exist to produce a change in a rock glacier system. Degradation of rock glaciers is generally measured from slumping surface morphology, frontal activity, amount of internal ice, variation in downslope movement, or temperature of the frozen material (Francou et al. 1999; Bosson and Lambiel 2016). A variety of geomorphic (internal structure, underlying topography, slope, curvature, etc.) and environmental (snowfall totals, snowmelt timing, temperature change, etc.) variables must be taken into account to properly evaluate the response of a rock glacier to 
climatic fluctuations. In case the active layer thickness exceeds the thickness of the bouldery layer, the internal ice core starts to melt, and the rock glacier commonly shows an overall surface thinning because of warming. On the Iberian Peninsula, geodetic surveys and GPS measurements on the Veleta rock glacier indicate dominant vertical subsidence compared to horizontal flow (de Sanjose-Blasco et al. 2007). On the Veleta rock glacier, Sierra Nevada, subsidence of dead ice has been consistent since 2001 (Ortiz et al., 2008). Some small-scale ridge advection or heaving may also be observed; advancing ice may cause compression or overthrusting near the toe (Kääb and Weber 2004; Chueca and Julian 2005; Janke, 2005 a, d; Kellerer-Pirklbauer et al. 2008). Although degradation of rock glaciers is much slower than of glaciers, they show a direct climate response, most evident in their movements (see section 1.13).

However, some rock glaciers have not shown a clear response to climate change. Field measurements for the Galena Creek (Wyoming) during the mid-1960s until 1995 and for Arapaho, Taylor, and Fair (Front Range) rock glaciers during 1961-2002 suggest that the velocities of these rock glaciers have not significantly changed in the measurement periods (Potter et al. 1998; Janke 2005d). During the warmer 1980s and 1990s, some rock glaciers in the European Alps have shown increasing subsidence rates by two to three times, decreasing horizontal velocities, and increasing borehole temperatures (Haeberli 1994; Barsch 1996; Kääb et al. 1997; Kaufmann and Ladstädter 2002).

However, an acceleration of the rock glacier flow during the last decades in response to increasing temperature has been found by both in-situ and remote sensing derived measurements for many rock glaciers in the Alps and Tien Shan (Kääb et al. 2007; Kääb et al. 2021; Marcer et al. 2021). Argualas rock glacier, Central Pyrenees, was surveyed between 1991 and 2000 using a total station; displacements showed temporal variations related to temperature change (Serrano et al. 2006). High surface flow rates (up to $3 \mathrm{~m} \mathrm{yr}^{-1}$ ) were measured near the front of 3 rock glaciers in the Austrian Alps using differential GPS. Analysis of the Reichenkar rock glacier in the Stubai Alps from 1954 to 1990 indicates a mean velocity of $6 \mathrm{~cm} \mathrm{yr}^{-1}$, whereas GPS measurements since 2001 indicate an increase of up to $30 \mathrm{~cm} \mathrm{yr}^{-1}$ (Hausmann et al. 2007). The 
Laurichard rock glacier in France has shown an increase in surface velocity and decreased in internal resistivity between 1980 and 2000s (Bodin et al. 2009).

\subsection{Hazards related to Rock glaciers}

The most common hazards related to rock glaciers are outburst of lakes that form on or are dammed by rock glaciers and rock avalanches originating from rock glacier fronts (Haeberli et al. 2001; Schoeneich et al. 2015) (Figures 33, 34). Degradation of permafrost near the front slope can increase the amount of erodible debris and reduce the mechanical stability of the rock glacier (Kneisel et al. 2007). Specifically, if the frontal part of the rock glaciers starts to accelerate strongly, crevasses or scarps can open, and the rock glaciers destabilize or even collapse (Roer et al. 2008; Bodin et al. 2017). In the case of rock glaciers located on steep slopes, this can result in a rockfall or a debris flow endangering the downstream area (Figure 34). Fast-flowing rock glaciers can also be the source of rockfall or trigger debris flows, as reported from rock glaciers in the Mattertal/Swiss Alps (Graf et al. 2013; Faillettaz et al. 2019).

In addition, the surface movements of rock glaciers themselves can cause some damage if structures like chair lifts or roads are built on a rock glacier. Special construction techniques were used to build a tramway station across a rock glacier located near Lone Mountain, MT (Figure 35). The rock glacier moves about 10 to $20 \mathrm{~cm} \mathrm{yr}^{-1}$, which is comparable to the stretch of the cable. To stabilize the station, gravel was placed on top of the rock glacier, covered by $20 \mathrm{~cm}$ thick 60-PSI blue board. This was covered by a $61 \mathrm{~cm}$ monolithic pad with massive amounts of rebar to build a 'boat' that floated on the surface of the rock glacier in 1995. The structure was weighted down (2600 t) in order to resist the force of the tram, which would cause it to slide across the blue board. The structure settled in a corner by $38 \mathrm{~cm}$ in 15 years because of ice 
ablation. Recently, the subsidence seems to have slowed (David Hamre personal communication).

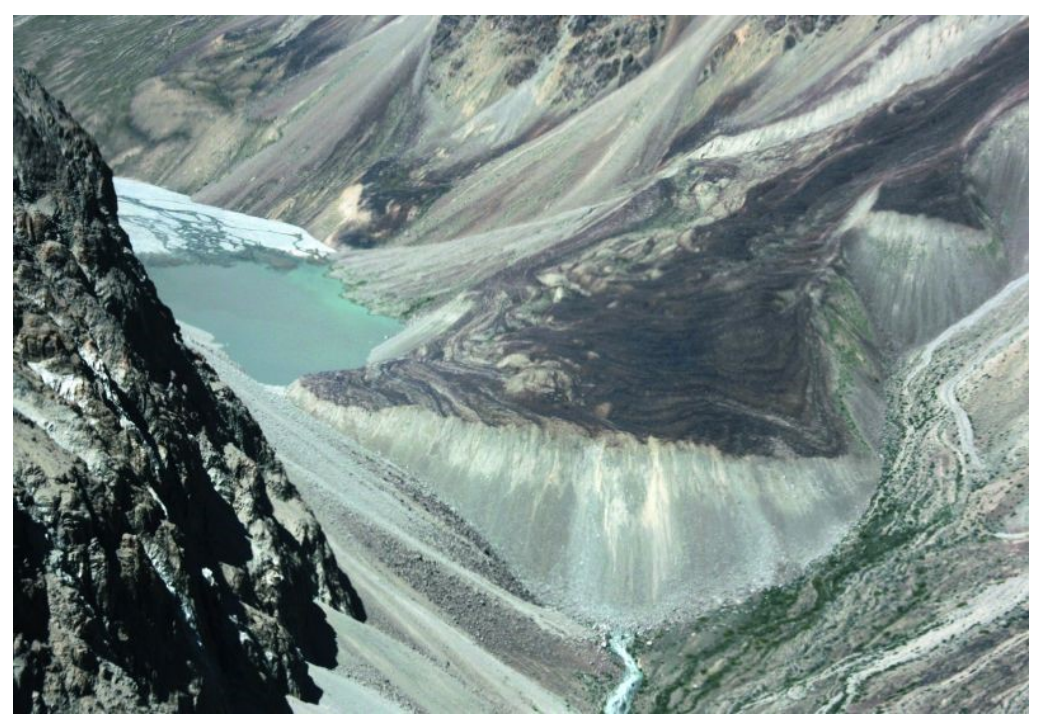

Figure 33 A rock glacier blocks a valley and forms Lake Sarez near Irkht in Tajikistan. 


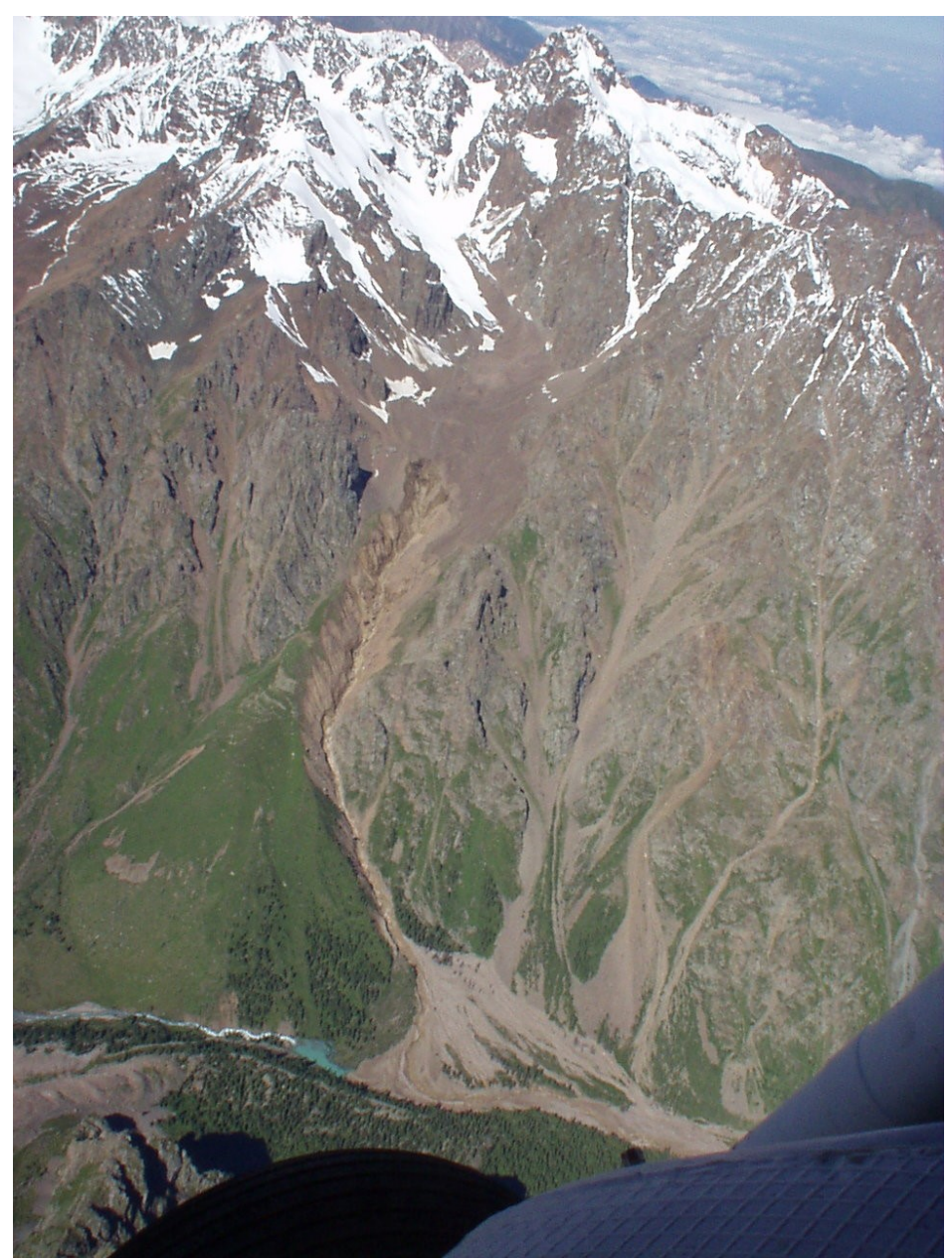

Figure 34 The 2003 debris flow in Left Talgar Valley (Ile Alatau, Tien Shan, Kazakhstan) originated from a degrading rock glacier front. Photo: Institute of Geography, Almaty. 


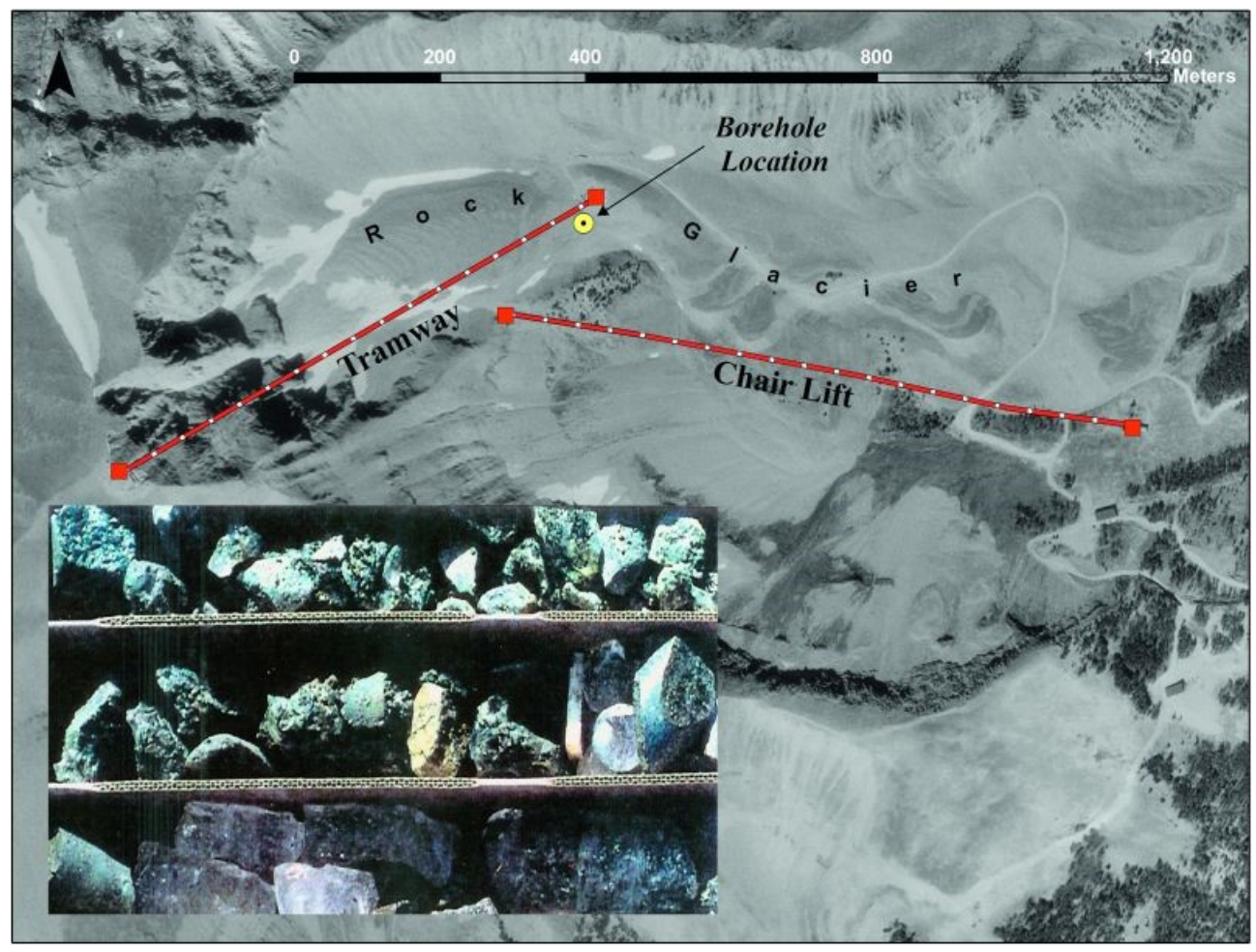

Figure 35 A rock glacier near Lone Mountain, MT, in the Big Sky ski resort is shown with a photo of a core sample ranging from 19.8 to $23.5 \mathrm{~m}$ depth. The ice-core shows both an ice-rock aggregate as well as pure ice. 


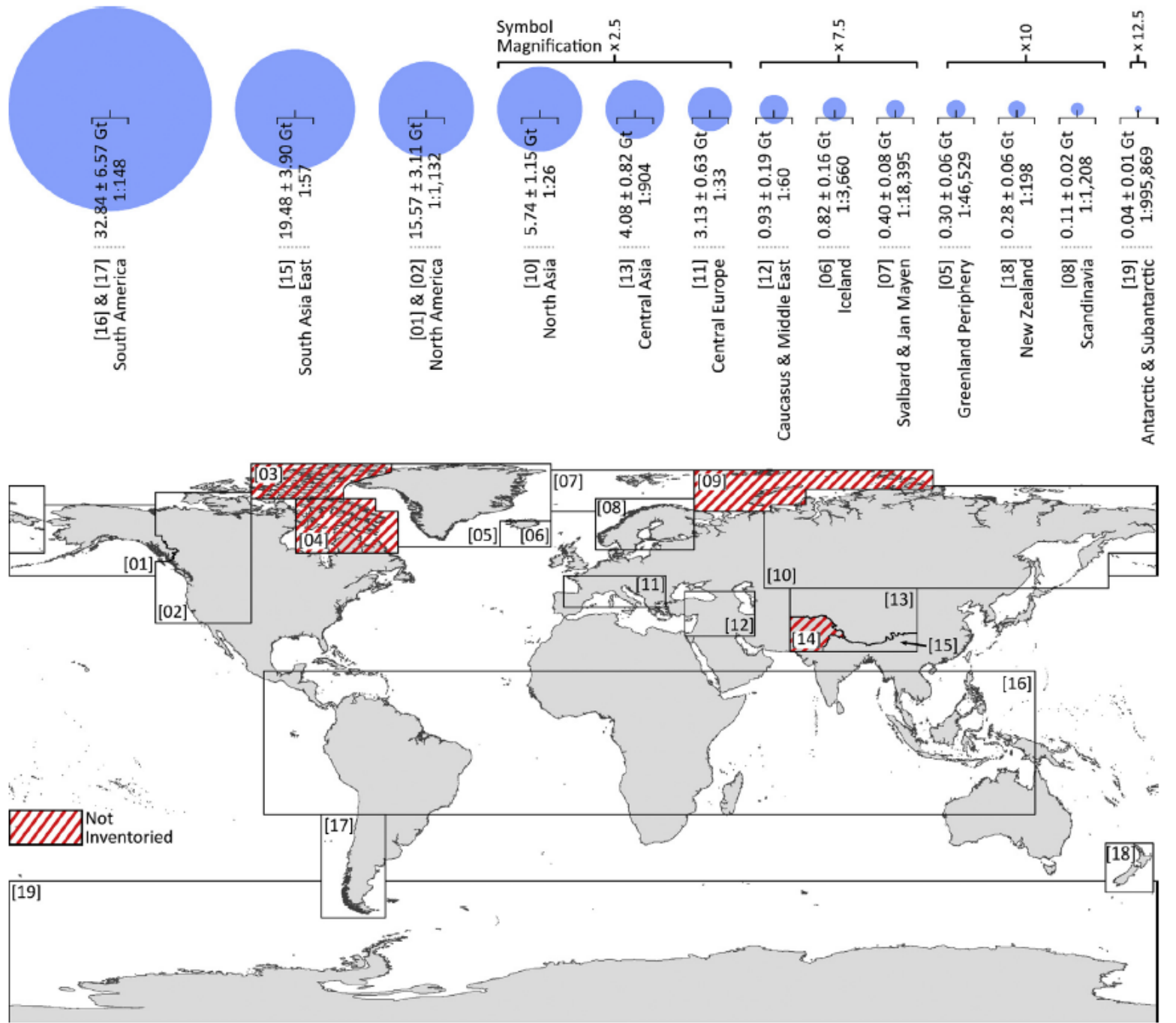

Figure 36 Estimated water volume equivalent stored in rock glaciers and glacier to rock glacier ratios based on existing inventories (Jones et al. 2019). Note: In many regions, no complete rock glacier inventory exists; some regions have no information about rock glacier occurrence.

\subsection{Future Research}

Even though the knowledge about rock glacier occurrence, origin, characteristics and response to climate has much improved, many knowledge gaps still exist. It is important to generate a complete and consistent world inventory of rock glaciers containing basic information such as location, area, length, width, elevation, aspect, slope and activity, and flow rates. Existing information need to be synthesized, and rock glaciers in missing areas should be mapped. Better 
information about distinguishing debris-covered glaciers from rock glaciers or investigating the glacier-rock glacier continuum under permafrost conditions is needed. The IPA action group of rock glacier kinematics and inventories was established in 2018 and is working on standardized guidelines and rock glacier mapping (IPA Action Group 2020).

Rock glaciers store a significant amount of water in alpine systems (Figure 36). These catchments provide drinking water for nearby communities. As the ice in rock glaciers and other periglacial ice-debris landforms such as ice-covered moraines (I-DLs) are more resilient to the atmospheric warming due to the insulating debris layer, they can somewhat counterbalance the expected declining glacier runoff (Figure 37). The effect of decaying ice that was previously stored in periglacial ice-debris landforms, including rock glaciers, needs to be assessed at the watershed scale and included in glacio-hydrological models. At present, no glacio-hydrological model includes the melt from rock glaciers for larger regions. Currently, local measurements from a few rock glaciers do not adequately represent additional periglacial inputs contained within a watershed. As ion selective probes and affordable laboratory work become more readily available, a better understanding of impacts on water quality will result.

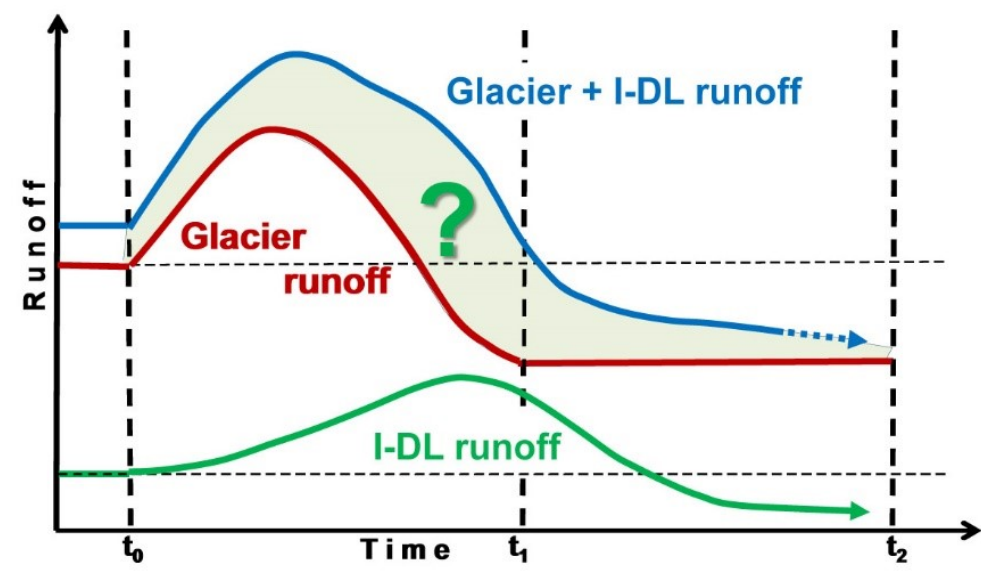

Figure 37 Conceptual figure about the potential future runoff from rock glaciers and other periglacial ice-debris landforms (I-DL). Figure: T. Bolch; the glacier runoff is adapted from (Huss and Hock 2018).

Much information remains to be discovered about the magnitude and timing of runoff from rock glaciers. A better estimate of the total ice content and dynamics of the active layers may 
help our understanding of water movement and storage. The characteristics and variability of the internal structure is another piece of critical information. Additional cores extracted would provide valuable insights but are only feasible at few sites because of the difficulty of getting coring equipment to remote sites and the associated high costs. Advanced geophysical methods allow more detailed information to be obtained (Hauck et al. 2011; Emmert and Kneisel 2017) but due to limited field access and difficulty to work on the boundary surface of the rock glaciers, the feasibility of geophysical investigations are also limited. Helicopter-borne measurements might allow more extensive coverage, although with lower accuracy (Merz et al. 2015).

Holistic studies which combine the information from various remote sensing methods and insitu information obtained from geophysics and other measurements have the potential to provide new detailed insights into the characteristics and climate response of rock glaciers and other periglacial ice-debris landforms (Capt et al. 2016; Bolch et al. 2019; Buckel et al. 2021; Halla et al. 2021).

An even more perplexing issue concerns the mechanism of the flow of rock glaciers. Few displacements measurements from boreholes provide important insights and show that in contrast to glaciers that most of the displacements take place at a shear horizon, unlike in glaciers. However, these are point measurements and more information is needed about the deformation of the ice or ice-debris mixture or the potential presence of sliding, especially of rock glaciers that that might have transitioned from debris-covered glaciers. More measurements and especially modelling studies (e.g., of the flow of rock glaciers) that combine a series of different techniques and data sources from different spatial and temporal scales are needed (Müller et al. 2016; Wirz et al. 2016; Kenner et al. 2017; Cicoira et al. 2019).

New geospatial techniques to monitor change show promise for future projects. Terrestrial LiDAR, very high-resolution stereo data obtained from very high-resolution satellite images or UAV, unmanned aerial systems, structure from motion through dense image mapping methods, or long-range terrestrial laser scanning could be used to measure detailed rock glacier kinematics (Abermann et al.et al. 2010; Kenner et al. 2014; Gomez-Gutierrez et al. 2014; Piermattei et al. 2016; Dall' Asta et al. 2017; Fey and Wichmann 2017; Vivero and Lambiel 2019; Halla et al. 2021). Deformation of ridges and furrow complexes or advancing or slumping front slopes could 
be monitored in sensitive areas at an unprecedented spatial scale. The availability of highresolution SAR sensors such as TerraSAR-X or SAR satellites with high repeat rates (e.g., Sentinel-1) allows detailed insight into the surface displacements and regular monitoring of rock glaciers (Barboux et al. 2014; Strozzi et al. 2020). Other very high-resolution space-borne hyperthermal sensors could be used to detect changing thermal patterns on the surface of rock glaciers. High-resolution GNSS measurements, coupled with wireless weather stations, could be used to measure real-time displacements or possibly even daily or seasonal movement. It would also be important in understanding the debris transport systems associated with rock glaciers (Müller et al. 2014) and to assess and monitor the hazard potential of rock glaciers (Faillettaz et al. 2019).

Rock glaciers are abundantly available in continental climates covering large areas and will continue to affect the alpine environment once glaciers have retreated. However, rock glaciers are vastly understudied compared to glaciers. The research community must inspire others to 
contribute their expertise to thoroughly understand and assess future impacts of an important alpine landform: rock glaciers.

Animations 1-8.

The online version of this chapter contains a Video with additional crystallographic data of compound 1-8. The online version can be found at doi:10.1016/B978-0-12-374739-6.00211-6

See Animation 1-8 which contains additional crystallographic data of compound 1-8. Animation 1 Terrestrial video of the Arapaho rock glacier, Front Range, CO. Animation 2 Fly-by of the Arapaho Valley depicting the Arapaho glacier and rock glacier, Front Range, CO.

Animation 3 Fly-by of Huerfano Valley and the California rock glacier located in southern Colorado.

Animation 4 Terrestrial video of the Fair rock glacier, Front Range, CO.

Animation 5 Fly-by of Taylor rock glacier in Rocky Mountain National Park, CO (IKONOS C) imagery in the backdrop).

Animation 6 Temporal aerial photographs which depict motion on the Middle St. Vrain rock glacier, Front Range, CO.

Animation 7 Motion on the Arapaho rock glacier, Front Range, CO.

Animation 8 Motion on the Taylor rock glacier, Front Range, CO. 
Tables

Table 1 Attributes of some rock glaciers found in the literature 


\begin{tabular}{|c|c|c|c|c|c|c|c|c|c|}
\hline Name/Location & Position & Form & Bedrock & Status & $\begin{array}{l}\text { Length } \\
\text { (m) }\end{array}$ & $\begin{array}{l}\text { Width } \\
\text { (m) }\end{array}$ & $\begin{array}{l}\text { Elevation } \\
\text { (m) }\end{array}$ & Latitude & Reference \\
\hline $\begin{array}{l}\text { Prins Karls Forland, } \\
\text { Western Svalbard }\end{array}$ & $\begin{array}{l}\text { Valley } \\
\text { wall }\end{array}$ & Lobate & Quartzite & Active & & 500 & & $70^{\circ} 50^{\prime} \mathrm{N}$ & $\begin{array}{l}\text { Berthling et al. } \\
\text { (1998) }\end{array}$ \\
\hline $\begin{array}{l}\text { Mullemfjord, Disko } \\
\text { Island, Greenland }\end{array}$ & Cirque & Tongue & Basalt & Active & 1700 & 500 & $100-200$ & $69^{\circ} 15^{\prime} \mathrm{N}$ & Humlum (1997) \\
\hline \multirow[t]{2}{*}{$\begin{array}{l}\text { Central Brooks } \\
\text { Range, Alaska, USA }\end{array}$} & $\begin{array}{l}\text { Valley } \\
\text { wall }\end{array}$ & Lobate & Sedimentary & $\begin{array}{l}\text { Active and } \\
\text { inactive }\end{array}$ & $10-210$ & & $900-2000$ & $\begin{array}{l}67^{\circ} 37^{\prime}-68^{\circ} \\
N\end{array}$ & $\begin{array}{l}\text { Calkin et al. } \\
\text { (1987) }\end{array}$ \\
\hline & Cirque & Tongue & & & $<3500$ & & $\begin{array}{l}1100- \\
1800\end{array}$ & $\begin{array}{l}67^{\circ} 37^{\prime}- \\
68^{\circ} \mathrm{N}\end{array}$ & \\
\hline $\begin{array}{l}\text { Kigluaik Mountains, } \\
\text { Alaska, USA }\end{array}$ & $\begin{array}{l}\text { Valley } \\
\text { floor }\end{array}$ & Tongue & $\begin{array}{l}\text { Metamorphic } \\
\text { Granite }\end{array}$ & Active & $350-800$ & & $500-930$ & $65^{\circ} \mathrm{N}$ & $\begin{array}{l}\text { Calkin et al. } \\
\text { (1998) }\end{array}$ \\
\hline \multirow[t]{2}{*}{ Alaska Range, USA } & $\begin{array}{l}\text { Valley } \\
\text { wall }\end{array}$ & Lobate & $\begin{array}{l}\text { Metamorphic } \\
\text { volcanic }\end{array}$ & $\begin{array}{l}\text { Active and } \\
\text { inactive }\end{array}$ & $60-1080$ & $90-3085$ & $865-1850$ & $\begin{array}{l}63^{\circ} 15^{\prime}- \\
64^{\circ} \mathrm{N}\end{array}$ & $\begin{array}{l}\text { Wahrhaftig and } \\
\text { Cox (1959) }\end{array}$ \\
\hline & Cirque & Tongue & & & $\begin{array}{l}150- \\
1540\end{array}$ & $60-775$ & & & \\
\hline $\begin{array}{l}\text { Grizzly Creek, } \\
\text { Yukon Territory, } \\
\text { Canada }\end{array}$ & Cirque & Lobate & $\begin{array}{l}\text { Metamorphosed } \\
\text { sediments; } \\
\text { intrusive } \\
\text { volcanics }\end{array}$ & $\begin{array}{l}\text { Active and } \\
\text { inactive }\end{array}$ & $\begin{array}{l}430- \\
1430\end{array}$ & $\begin{array}{l}200- \\
1000\end{array}$ & $\begin{array}{l}1650- \\
2000\end{array}$ & $61^{\circ} \mathrm{N}$ & Johnson (1987) \\
\hline
\end{tabular}




\begin{tabular}{|c|c|c|c|c|c|c|c|c|c|}
\hline Name/Location & Position & Form & Bedrock & Status & $\begin{array}{l}\text { Length } \\
\text { (m) }\end{array}$ & $\begin{array}{l}\text { Width } \\
\text { (m) }\end{array}$ & $\begin{array}{l}\text { Elevation } \\
\text { (m) }\end{array}$ & Latitude & Reference \\
\hline $\begin{array}{l}\text { Valais Region, } \\
\text { Switzerland }\end{array}$ & $\begin{array}{l}\text { Valley } \\
\text { floor }\end{array}$ & Lobate & & Active & 600 & & $2650-300$ & $46^{\circ} \mathrm{N}$ & Pancza (1998) \\
\hline $\begin{array}{l}\text { Murtèl/Corvatsch, } \\
\text { Grisons, Swiss Alps }\end{array}$ & Cirque & Tongue & Granodiorite & Active & 400 & 200 & $\begin{array}{l}2620- \\
2850\end{array}$ & & $\begin{array}{l}\text { Haeberli et al. } \\
\text { (1988), Vonder } \\
\text { Mühll and } \\
\text { Klingelé (1994) }\end{array}$ \\
\hline $\begin{array}{l}\text { Laurichard, French } \\
\text { Alps }\end{array}$ & & Tongue & Granite & Active & 400 & $40-200$ & 2500 & $45^{\circ} \mathrm{N}$ & $\begin{array}{l}\text { Francou and } \\
\text { Reynaud (1992) }\end{array}$ \\
\hline $\begin{array}{l}\text { Galena Creek, } \\
\text { Absaroka } \\
\text { Mountains, USA }\end{array}$ & Cirque & Tongue & Volcanic & Active & 1600 & $240-300$ & $\begin{array}{l}2680- \\
3110\end{array}$ & $44^{\circ} 38^{\prime} 30^{\prime \prime} \mathrm{N}$ & Potter (1972) \\
\hline $\begin{array}{l}\text { Lombardy, Italian } \\
\text { Alps }\end{array}$ & $\begin{array}{l}45 \% \\
\text { Cirque }\end{array}$ & Lobate & $\begin{array}{l}76 \% \\
\text { Metamorphic }\end{array}$ & $\begin{array}{l}\text { Active and } \\
\text { inactive }\end{array}$ & 535 & 326 & $\begin{array}{l}2110- \\
2540\end{array}$ & & $\begin{array}{l}\text { Guglielmin et } \\
\text { al. (2001) }\end{array}$ \\
\hline \multirow[t]{4}{*}{$\begin{array}{l}\text { Mount Emilius, } \\
\text { Valle d'Aosta, Italy }\end{array}$} & $\begin{array}{l}\text { Valley } \\
\text { wall }\end{array}$ & Lobate & $\begin{array}{l}\text { Gneiss, calc - } \\
\text { schist, } \\
\text { greenstones }\end{array}$ & Active & 190 & 200 & 2815 & & $\begin{array}{l}\text { Guglielmin et } \\
\text { al. (1994) }\end{array}$ \\
\hline & & & & Inactive & 140 & 150 & 2550 & & \\
\hline & Cirque & Lobate & & Inactive & 470 & 240 & 2310 & & \\
\hline & & & & Active & 470 & 270 & 3000 & & \\
\hline
\end{tabular}




\begin{tabular}{|c|c|c|c|c|c|c|c|c|c|}
\hline Name/Location & Position & Form & Bedrock & Status & $\begin{array}{l}\text { Length } \\
\text { (m) }\end{array}$ & $\begin{array}{l}\text { Width } \\
\text { (m) }\end{array}$ & $\begin{array}{l}\text { Elevation } \\
\text { (m) }\end{array}$ & Latitude & Reference \\
\hline & $\begin{array}{l}\text { Valley } \\
\text { floor }\end{array}$ & Tongue & & Active & 1800 & & 2600 & & \\
\hline $\begin{array}{l}\text { SW Alps, France } \\
\text { and Italy }\end{array}$ & & Lobate & $\begin{array}{l}\text { Metamorphic } \\
\text { limestone }\end{array}$ & $\begin{array}{l}\text { Active and } \\
\text { inactive }\end{array}$ & $200-300$ & & $\begin{array}{l}1500- \\
2850\end{array}$ & $44^{\circ} \mathrm{N}$ & Evin (1987) \\
\hline $\begin{array}{l}\text { Urumqi River, } \\
\text { Tianshan Mountains }\end{array}$ & $\begin{array}{l}\text { Valley } \\
\text { fide }\end{array}$ & Lobate & Gneiss & Active & $30-60$ & $100-150$ & 3900 & $\begin{array}{l}43^{\circ} 04^{\prime}- \\
43^{\circ} 08^{\prime} \mathrm{N}\end{array}$ & $\begin{array}{l}\text { Cui and Cheng } \\
\text { (1988) }\end{array}$ \\
\hline $\begin{array}{l}\text { Northern Tian Shan } \\
\text { and Djungar Ala } \\
\text { Tau, Kazakhstan }\end{array}$ & $\begin{array}{l}\text { River } \\
\text { basin }\end{array}$ & Tongue & Granite & Active & $\begin{array}{l}750- \\
2000\end{array}$ & $350-980$ & $\begin{array}{l}2100- \\
3500\end{array}$ & $\begin{array}{l}42^{\circ} 30^{\prime}- \\
45^{\circ} 30^{\prime} \mathrm{N}\end{array}$ & $\begin{array}{l}\text { Gorbunov and } \\
\text { Titkov (1992) }\end{array}$ \\
\hline \multirow[t]{2}{*}{ Albanian Alps } & & Tongue & $\begin{array}{l}\text { Carbonates, } \\
\text { Flysch, } \\
\text { magmatic }\end{array}$ & Inactive & $\begin{array}{l}200- \\
1000\end{array}$ & $75-325$ & $\begin{array}{l}1690- \\
2200\end{array}$ & $\begin{array}{l}42^{\circ} 27^{\prime}- \\
42^{\circ} 33^{\prime} \mathrm{N}\end{array}$ & $\begin{array}{l}\text { Palmentola et } \\
\text { al. (1995) }\end{array}$ \\
\hline & & Lobate & & & $120-200$ & $100-130$ & & & \\
\hline $\begin{array}{l}\text { Colorado Front } \\
\text { Range, USA }\end{array}$ & Cirque & Lobate & Granite & Active & $405-640$ & $170-215$ & $\begin{array}{l}3320- \\
3710\end{array}$ & $\begin{array}{l}40^{\circ} 01^{\prime}- \\
40^{\circ} 16^{\prime} \mathrm{N}\end{array}$ & $\begin{array}{l}\text { White (1971), } \\
\text { White (1987); } \\
\text { Benedict et al. } \\
\text { (1986) }\end{array}$ \\
\hline $\begin{array}{l}\text { Mosquito Range, } \\
\text { Colorado, USA }\end{array}$ & $\begin{array}{l}\text { Valley } \\
\text { wall }\end{array}$ & Lobate & Granodiorite & Inactive & $90-275$ & $180-600$ & $\begin{array}{l}3330- \\
3975\end{array}$ & $\begin{array}{l}39^{\circ} 10^{\prime}- \\
39^{\circ} 17^{\prime} \mathrm{N}\end{array}$ & Vick (1987) \\
\hline
\end{tabular}




\begin{tabular}{|c|c|c|c|c|c|c|c|c|c|}
\hline Name/Location & Position & Form & Bedrock & Status & $\begin{array}{l}\text { Length } \\
\text { (m) }\end{array}$ & $\begin{array}{l}\text { Width } \\
\text { (m) }\end{array}$ & $\begin{array}{l}\text { Elevation } \\
\text { (m) }\end{array}$ & Latitude & Reference \\
\hline \multirow[t]{2}{*}{$\begin{array}{l}\text { La Sal Mountain, } \\
\text { Utah, USA }\end{array}$} & $\begin{array}{l}\text { Valley } \\
\text { wall, } \\
\text { Floor } \\
\text { cirque }\end{array}$ & Lobate & $\begin{array}{l}\text { Igneous, } \\
\text { sedimentary }\end{array}$ & $\begin{array}{l}\text { Active and } \\
\text { inactive }\end{array}$ & $\begin{array}{l}400- \\
1000\end{array}$ & $150-800$ & $\begin{array}{l}2200- \\
3550\end{array}$ & $\begin{array}{l}37^{\circ} 42^{\prime}- \\
38^{\circ} 15^{\prime} \mathrm{N}\end{array}$ & $\begin{array}{l}\text { Shroder (1987), } \\
\text { Nicholas and } \\
\text { Butler (1996); } \\
\text { Nicholas and } \\
\text { Garcia (1997) }\end{array}$ \\
\hline & Cirque & Tongue & & & & & & & \\
\hline \multirow[t]{2}{*}{$\begin{array}{l}\text { Blanca Massif } \\
\text { Colorado, USA }\end{array}$} & $\begin{array}{l}\text { Valley } \\
\text { wall }\end{array}$ & Lobate & $\begin{array}{l}\text { Granitic, } \\
\text { metamorphic }\end{array}$ & & $95-295$ & $\begin{array}{l}195- \\
1100\end{array}$ & $\begin{array}{l}3600- \\
3885\end{array}$ & $\begin{array}{l}37^{\circ} 37^{\prime}- \\
37^{\circ} 37^{\prime} 30^{\prime \prime} \\
\mathrm{N}\end{array}$ & $\begin{array}{l}\text { Morris (1981), } \\
\text { Parson (1987) }\end{array}$ \\
\hline & Cirque & Tongue & & & $400-480$ & $110-160$ & $\begin{array}{l}3700- \\
3750\end{array}$ & $\begin{array}{l}37^{\circ} 37^{\prime}- \\
37^{\circ} 37^{\prime} 30^{\prime \prime} \\
\mathrm{N}\end{array}$ & \\
\hline $\begin{array}{l}\text { California rock } \\
\text { glacier, Blanca } \\
\text { Massif, USA }\end{array}$ & Cirque & Tongue & & Active & 1460 & 290 & 3625 & $37^{\circ} 37^{\prime} 30^{\prime} \mathrm{N}$ & \\
\hline $\begin{array}{l}\text { Mount Mestas, } \\
\text { Colorado USA }\end{array}$ & $\begin{array}{l}\text { Valley } \\
\text { wall }\end{array}$ & Tongue & $\begin{array}{l}\text { Intrusive } \\
\text { igneous }\end{array}$ & Active & $\begin{array}{l}130- \\
1930\end{array}$ & $50-645$ & $\begin{array}{l}2650- \\
3315\end{array}$ & $37^{\circ} 35^{\prime}$ & Giardino (1979) \\
\hline
\end{tabular}




\begin{tabular}{|c|c|c|c|c|c|c|c|c|c|}
\hline Name/Location & Position & Form & Bedrock & Status & $\begin{array}{l}\text { Length } \\
\text { (m) }\end{array}$ & $\begin{array}{l}\text { Width } \\
\text { (m) }\end{array}$ & $\begin{array}{l}\text { Elevation } \\
\text { (m) }\end{array}$ & Latitude & Reference \\
\hline $\begin{array}{l}\text { South Fork Pass, } \\
\text { Sierra Nevada, USA }\end{array}$ & $\begin{array}{l}\text { Valley } \\
\text { floor }\end{array}$ & Tongue & $\begin{array}{l}\text { Granodiorite, } \\
\text { quartz } \\
\text { monzonite }\end{array}$ & Active & 1600 & $200-300$ & $\begin{array}{l}3410- \\
3740\end{array}$ & $\begin{array}{l}36^{\circ} 25^{\prime}- \\
37^{\circ} 25^{\prime} \mathrm{N}\end{array}$ & $\begin{array}{l}\text { Clark and Clark } \\
\text { (1994) }\end{array}$ \\
\hline $\begin{array}{l}\text { Pokalde Massif, } \\
\text { Khumbu Himalaya }\end{array}$ & Cirque & Tongue & & Active & $\begin{array}{l}410- \\
1100\end{array}$ & $100-250$ & $\begin{array}{l}4990- \\
5400\end{array}$ & $\begin{array}{l}27^{\circ} 55^{\prime}-28^{\circ} \\
N\end{array}$ & $\begin{array}{l}\text { Barsch and } \\
\text { Jakob (1998) }\end{array}$ \\
\hline $\begin{array}{l}\text { Lenana, Mount } \\
\text { Kenya }\end{array}$ & $\begin{array}{l}\text { Valley } \\
\text { side }\end{array}$ & Lobate & $\begin{array}{l}\text { Nephaline } \\
\text { syenite }\end{array}$ & Inactive & 300 & 340 & 4750 & $0^{\circ}$ & Grab (1996) \\
\hline $\begin{array}{l}\text { Mendoza, } \\
\text { Argentina, Central } \\
\text { Andes }\end{array}$ & & Tongue & & $\begin{array}{l}\text { Active and } \\
\text { inactive }\end{array}$ & 2100 & 500 & $\begin{array}{l}3200- \\
4800\end{array}$ & $31^{\circ}-36^{\circ} \mathrm{S}$ & Corte (1987) \\
\hline $\begin{array}{l}\text { Kanchanjunga } \\
\text { Himal, Eastern } \\
\text { Nepal }\end{array}$ & & Lobate & & Active & 280 & 140 & $\begin{array}{l}4800- \\
5300\end{array}$ & $27^{\circ} \mathrm{N}$ & $\begin{array}{l}\text { Ishikawa et al. } \\
\text { (2001) }\end{array}$ \\
\hline $\begin{array}{l}\text { Cordillera Principal, } \\
\text { San Juan, Argentina }\end{array}$ & Cirque & Tongue & Andesite & Active & $\begin{array}{l}1250- \\
1900\end{array}$ & & $\begin{array}{l}4000- \\
4900\end{array}$ & $30^{\circ} \mathrm{S}$ & Schrott (1991) \\
\hline
\end{tabular}

Source: Reproduced from Burger, K.C., Degenhardt, J.J., Giardino, J.R., 1999. Engineering geomorphology of rock glaciers.

Geomorphology 31, 93-132.

(Adapted from Burger, K.C., Degenhardt, J.J., Giardino, J.R., 1999. Engineering geomorphology of rock glaciers. Geomorphology 31, 93-132 with permission) 
Table 2 Electromagnetic properties of common earth materials

\begin{tabular}{|l|l|l|l|l|}
\hline Material & $\begin{array}{l}\text { Permittivity } \\
(\varepsilon)\end{array}$ & $\begin{array}{l}\text { Electrical Conductivity }(\sigma, \mathrm{mS} \\
\left.\mathrm{m}^{-1}\right)^{\mathrm{a}}\end{array}$ & $\begin{array}{l}\text { Propagation Velocity (v, m } \\
\left.\mathbf{n s}^{-1}\right)\end{array}$ & $\begin{array}{l}\text { Attenuation }(\alpha, \mathrm{DB} \\
\left.\mathrm{m}^{-1}\right)\end{array}$ \\
\hline $\begin{array}{l}\text { Fresh } \\
\text { Water }\end{array}$ & 81 & 0.5 & 0.03 & 0.1 \\
\hline Clay & $5-40$ & $2-1,00000$ & 0.06 & $1-300$ \\
\hline Silt & $5-30$ & $1-100$ & 0.07 & $1-100$ \\
\hline Shale & $5-15$ & $1-100$ & 0.09 & $1-100$ \\
\hline Limestone & $4-8$ & $0.5-2$ & 0.12 & $0.4-1$ \\
\hline Granite & $4-6$ & $0.1-1$ & 0.13 & $0.01-1$ \\
\hline Dry Sand & $3-5$ & 0.01 & 0.15 & 0.01 \\
\hline Ice & $3-4$ & 0.01 & 0.16 & 0.01 \\
\hline Wet Sand & $20-30$ & $0.1-1$ & 0.6 & $0.03-0.3$ \\
\hline
\end{tabular}

a Reciprocal of electrical resistivity.

Table 3 Summary of selected rates of flow studies 


\begin{tabular}{|c|c|c|c|c|c|}
\hline Location & Method & Years & Motion & Rates/flow patterns & References \\
\hline $\begin{array}{l}\text { Galena Creek, Absaroka } \\
\text { Mountains, WY }\end{array}$ & Field surveying & $1960 \mathrm{~s}$ & Horizontal & $\begin{array}{l}\text { Upper: } 80 \mathrm{~cm} \mathrm{yr}^{-1} \text {; middle: } 6 \\
\mathrm{~cm} \mathrm{yr}^{-1} \text {; lower: } 14 \mathrm{~cm} \mathrm{yr}^{-1}\end{array}$ & Potter (1972) \\
\hline $\begin{array}{l}\text { Galena Creek, Absaroka } \\
\text { Mountains, WY }\end{array}$ & Field surveying & $\begin{array}{l}1960 \mathrm{~s}-1990 \mathrm{~s} \\
\text { (30-year interval) }\end{array}$ & Horizontal & Within $10 \%$ of above & $\begin{array}{l}\text { Potter et al. } \\
\text { (1998) }\end{array}$ \\
\hline $\begin{array}{l}\text { Clear Creek, Wrangel } \\
\text { Mountains, AK }\end{array}$ & Field surveying & $1949-1957$ & Horizontal & $\begin{array}{l}\text { Upper: } 64 \mathrm{~cm} \mathrm{yr}^{-1} \text {; lower: } 57 \\
\mathrm{~cm} \mathrm{yr}^{-1}\end{array}$ & $\begin{array}{l}\text { Wahrhaftig and } \\
\text { Cox (1959) }\end{array}$ \\
\hline Arapaho, Front Range, CO & Field surveying & $\begin{array}{l}\text { 1960-1985 (25- } \\
\text { year interval) }\end{array}$ & Horizontal & $\begin{array}{l}\text { Center: } 19.3 \mathrm{~cm} \mathrm{yr}^{-1} \text {; edges: } 6.2 \\
\mathrm{~cm} \mathrm{yr}^{-1}\end{array}$ & $\begin{array}{l}\text { Benedict et al. } \\
\text { (1986) }\end{array}$ \\
\hline $\begin{array}{l}\text { Maroon and Pyramid, Elk } \\
\text { Mountains, CO }\end{array}$ & Field surveying & $1964-1968$ & Horizontal & Average: $63 \mathrm{~cm} \mathrm{yr}^{-1}$ & Bryant (1971) \\
\hline $\begin{array}{l}\text { King's Throne, Canadian } \\
\text { Rocky Mountains }\end{array}$ & Field surveying & $\begin{array}{l}\text { 1988-1989; } \\
1988-1996\end{array}$ & $\begin{array}{l}\text { Horizontal/ } \\
\text { Vertical }\end{array}$ & $\begin{array}{l}\text { Horizontal average: } 5.35 \mathrm{~cm} \\
\mathrm{yr}^{-1} \text {; vertical average: } 2.49 \mathrm{~cm} \\
\mathrm{yr}^{-1}\end{array}$ & $\begin{array}{l}\text { Koning and } \\
\text { Smith (1999) }\end{array}$ \\
\hline $\begin{array}{l}\text { Selwyn Mountains, Yukon } \\
\text { and NW Territories }\end{array}$ & Field surveying & $1983-1995$ & Horizontal & $\begin{array}{l}\text { Horizontal average: } 18 \mathrm{~cm} \\
\mathrm{yr}^{-1} \pm 12 \mathrm{~cm}\end{array}$ & $\begin{array}{l}\text { Sloan and Dyke } \\
\text { (1998) }\end{array}$ \\
\hline $\begin{array}{l}\text { Arapaho, Taylor, and Fair, } \\
\text { Front Range, CO }\end{array}$ & Field surveying & $1961-1966$ & Horizontal & $\begin{array}{l}\text { Arapaho: } 5.0 \mathrm{~cm} \mathrm{yr}^{-1} \text {; Taylor: } \\
6.6 \mathrm{~cm} \mathrm{yr}^{-1} \text {; Fair: } 9.7 \mathrm{~cm} \mathrm{yr}^{-1}\end{array}$ & White (1971) \\
\hline $\begin{array}{l}\text { Arapaho, Taylor, and Fair, } \\
\text { Front Range, CO }\end{array}$ & Field surveying & $1961-2002$ & Horizontal & $\begin{array}{l}\text { Arapaho: } 7.3 \mathrm{~cm} \mathrm{yr}^{-1} \text {; Taylor: } \\
6.3 \mathrm{~cm} \mathrm{yr}^{-1} \text {; Fair: } 9.5 \mathrm{~cm} \mathrm{yr}^{-1}\end{array}$ & Janke (2005d) \\
\hline
\end{tabular}




\begin{tabular}{|c|c|c|c|c|c|}
\hline Location & Method & Years & Motion & Rates/flow patterns & References \\
\hline $\begin{array}{l}\text { Hiorthfjellet rock glacier, } \\
\text { Svalbard }\end{array}$ & Field surveying & 1994-2002 & Horizontal & 9.5 to $10.8 \mathrm{~cm} \mathrm{yr}^{-1}$ & $\begin{array}{l}\text { Odergard et al. } \\
(2003)\end{array}$ \\
\hline $\begin{array}{l}\text { Macun I, Lower Engadine, } \\
\text { Swiss Alps }\end{array}$ & Field surveying & $1967-1988$ & Horizontal & $\begin{array}{l}14.2 \pm 0.4 \mathrm{~cm} \mathrm{yr}^{-1} \text {; unlikely to be } \\
\text { sliding }\end{array}$ & $\begin{array}{l}\text { Barsch and Zick } \\
\text { (1991) }\end{array}$ \\
\hline Nautardalur, North Iceland & Field surveying & $1977-1994$ & Horizontal & $\begin{array}{l}\text { Center line velocities average } \\
25 \mathrm{~cm} \mathrm{yr}^{-1} \text {; no sliding is evident }\end{array}$ & $\begin{array}{l}\text { Whalley et al. } \\
\text { (1995) }\end{array}$ \\
\hline Reichenkar, Stubai Alps & Field surveying & & Horizontal & $\begin{array}{l}\text { Rates greater than } 200 \mathrm{~cm} \mathrm{yr}^{-1} \text {; } \\
\text { basal sliding present }\end{array}$ & $\begin{array}{l}\text { Krainer and } \\
\text { Mostler (2000) }\end{array}$ \\
\hline Weissmies, South Wallis & $\begin{array}{l}\text { Aerial photography: } \\
\text { point-to-point }\end{array}$ & $1958-1964$ & Horizontal/vertical & $\begin{array}{l}\text { Horizontal: maximum in center: } \\
60 \mathrm{~cm} \mathrm{yr}^{-1} \text {; vertical: toe: }-30 \\
\mathrm{~cm} \mathrm{yr}^{-1}\end{array}$ & $\begin{array}{l}\text { Messerli and } \\
\text { Zurbuchen } \\
\text { (1968) from } \\
\text { Barsch (1996) }\end{array}$ \\
\hline $\begin{array}{l}\text { Grosses Gufer, North } \\
\text { Wallis }\end{array}$ & $\begin{array}{l}\text { Aerial photography: } \\
\text { point-to-point }\end{array}$ & $1950-1962$ & Horizontal/vertical & $\begin{array}{l}\text { Horizontal: lower section: } 50 \\
\mathrm{~cm} \mathrm{yr}^{-1} \text {; vertical: toe: }-20 \mathrm{~cm} \\
\mathrm{yr}^{-1}\end{array}$ & $\begin{array}{l}\text { Messerli and } \\
\text { Zurbuchen } \\
\text { (1968) from } \\
\text { Barsch (1996) }\end{array}$ \\
\hline
\end{tabular}




\begin{tabular}{|l|l|l|l|l|l|}
\hline Location & Method & Years & Motion & Rates/flow patterns & References \\
\hline Murtèl I, Swiss Alps & $\begin{array}{l}\text { Aerial photography: } \\
\text { point-to-point }\end{array}$ & $1932-1971$ & $\begin{array}{l}\text { Horizontal/ } \\
\text { vertical }\end{array}$ & $\begin{array}{l}\text { Horizontal: } 5.1 \pm 3 \mathrm{~cm} \mathrm{yr}^{-1} ; \\
\text { velocities slowed by some } 46 \% \\
\text { over 2nd half of study vertical: } \\
-2.8 \pm 1 \mathrm{~cm} \mathrm{yr}^{-1} \text {; surface } \\
\text { lowering during first part, rising } \\
\text { during second half }\end{array}$ & $\begin{array}{l}\text { Barsch and Hell } \\
(1975)\end{array}$ \\
\hline $\begin{array}{l}\text { Six rock glaciers, Northern } \\
\text { Tien Shan and Djungar Ala } \\
\text { Tau, Kazakhstan }\end{array}$ & $\begin{array}{l}\text { Aerial photography: } \\
\text { point-to-point and } \\
\text { Field surveys }\end{array}$ & $1969-1984$ & Horizontal & Rates vary: 20-146 $\mathrm{cm} \mathrm{yr}^{-1}$ & $\begin{array}{l}\text { Gorbunov and } \\
\text { Titkov (1992) }\end{array}$ \\
\hline $\begin{array}{l}\text { Gruben, Swiss Alps } \\
\text { Aerial photography: } \\
50 \text { by } 50 \text { m grid }\end{array}$ & $1970-1975$ & Horizontal & $\begin{array}{l}\text { Greatest near the rock glacier } \\
\text { head and toe due to extensional } \\
\text { flow, compression near the } \\
\text { interior }\end{array}$ & $\begin{array}{l}\text { Haeberli } \text { et al. } \\
(1979)\end{array}$ \\
\hline Doesen, Austrian Alps & $\begin{array}{l}\text { Aerial photography: } \\
\text { computer point-to- } \\
\text { point }\end{array}$ & $1954-1993$ & Horizontal/vertical & $\begin{array}{l}\text { Horizontal: } 14.3 \mathrm{~cm} \mathrm{yr}^{-1} ; \\
\text { vertical: }-1.9 \mathrm{~cm} \mathrm{yr}^{-1}\end{array}$ & $\begin{array}{l}\text { Kaufmann } \\
(1998)\end{array}$ \\
\hline
\end{tabular}




\begin{tabular}{|c|c|c|c|c|c|}
\hline Location & Method & Years & Motion & Rates/flow patterns & References \\
\hline Gruben, Swiss Alps & $\begin{array}{l}\text { Aerial photography: } \\
\text { computer } 50 \text { by } 50 \mathrm{~m} \\
\text { grid }\end{array}$ & 1970-1979 & Horizontal/vertical & $\begin{array}{l}\text { Horizontal: most total } \\
\text { displacements range from } 0 \text { to } \\
400 \mathrm{~cm} \text {; vertical: Permafrost } \\
\text { region: } 50 \text { to } 150 \mathrm{~cm} \text {, glacier } \\
\text { region: } 150 \mathrm{~cm}\end{array}$ & $\begin{array}{l}\text { Haeberli and } \\
\text { Schmid (1988) }\end{array}$ \\
\hline Gruben, Swiss Alps & $\begin{array}{l}\text { Aerial photography: } \\
\text { computer } 25 \text { by } 25 \mathrm{~m} \\
\text { grid }\end{array}$ & 1970-1995 & Horizontal/vertical & $\begin{array}{l}\text { Horizontal: reached values of } \\
100 \mathrm{~cm} \mathrm{yr}^{-1} \text { with some showing } \\
20 \% \text { change over a few years; } \\
\text { vertical: Permafrost region: } \\
\text { average of }-5 \mathrm{~cm} \mathrm{yr}^{-1} \text {, glacier } \\
\text { region: average of }-20 \mathrm{~cm} \mathrm{yr}^{-1}\end{array}$ & $\begin{array}{l}\text { Kääb et al. } \\
\text { (1997) }\end{array}$ \\
\hline Murtèl, Swiss Alps & $\begin{array}{l}\text { Aerial photography: } \\
\text { computer } 10 \text { by } 10 \mathrm{~m} \\
\text { grid }\end{array}$ & $1987-1996$ & Horizontal/vertical & $\begin{array}{l}\text { Horizontal: head: } 15 \mathrm{~cm} \mathrm{yr}^{-1} \text {; } \\
\text { toe: } 5 \mathrm{~cm} \mathrm{yr}^{-1} \text {; vertical: }-4 \mathrm{~cm} \\
\mathrm{yr}^{-1}\end{array}$ & $\begin{array}{l}\text { Kääb et al. } \\
(1998)\end{array}$ \\
\hline Muragl, Swiss Alps & $\begin{array}{l}\text { Digital aerial } \\
\text { photography: cross } \\
\text { correlation with a } 3 \\
\text { by } 3 \mathrm{~m} \text { grid }\end{array}$ & 1981-1994 & Horizontal/vertical & $\begin{array}{l}\text { Horizontal: up to } 50 \mathrm{~cm} \mathrm{yr}^{-1} \text {; } \\
\text { vertical: most in the range of } \\
\pm 10 \mathrm{~cm} \mathrm{yr}^{-1}\end{array}$ & $\begin{array}{l}\text { Kääb and } \\
\text { Vollmer (2000); } \\
\text { Kääb (2002) }\end{array}$ \\
\hline
\end{tabular}




\begin{tabular}{|c|c|c|c|c|c|}
\hline Location & Method & Years & Motion & Rates/flow patterns & References \\
\hline $\begin{array}{l}\text { Outer Hochebenkar, } \\
\text { Oetztal Alps }\end{array}$ & $\begin{array}{l}\text { Digital aerial } \\
\text { photography: cross- } \\
\text { correlation with } \\
\text { random point-to- } \\
\text { point matching }\end{array}$ & $1953-1997$ & Horizontal/vertical & $\begin{array}{l}\text { Horizontal: maximum of } 1.8 \mathrm{~m} \\
\mathrm{yr}^{-1} \text { with slower rates in the } \\
1980 \mathrm{~s} \text {; vertical: maximum } \\
\text { lowering of } 1,800 \mathrm{~cm} \text { over } 44 \\
\text { years }\end{array}$ & $\begin{array}{l}\text { Kaufmann and } \\
\text { Ladstädter } \\
(2002)\end{array}$ \\
\hline $\begin{array}{l}\text { Inner Hochebenkar, } \\
\text { Oetztal Alps }\end{array}$ & $\begin{array}{l}\text { Digital aerial } \\
\text { photography: cross- } \\
\text { correlation with } \\
\text { random point-to- } \\
\text { point matching }\end{array}$ & 1954-1997 & Horizontal/vertical & $\begin{array}{l}\text { Horizontal: two active sections } \\
\text { seperated by an inactive } \\
\text { section; vertical: maximum } \\
\text { lowering of } 80 \mathrm{~cm} \text { over } 44 \\
\text { years }\end{array}$ & $\begin{array}{l}\text { Kaufmann and } \\
\text { Ladstädter } \\
(2002)\end{array}$ \\
\hline $\begin{array}{l}\text { Various rock glaciers, } \\
\text { Front Range, } \mathrm{CO}\end{array}$ & $\begin{array}{l}\text { Digital aerial } \\
\text { photography: point- } \\
\text { to-point }\end{array}$ & $1978-1999$ & Horizontal/vertical & 14 to $20 \mathrm{~cm} \mathrm{yr}^{-1}$ & Janke (2005a) \\
\hline
\end{tabular}




\section{References}

Abermann, J., Fischer, A., Lambrecht, A., and Geist, T., 2010, On the potential of very high-resolution repeat DEMs in glacial and periglacial environments: The Cryosphere, v. 4, no. 1, p. 53-65.

Ackert, R. P., 1998, A rock glacier/debris-covered glacier system at Galena Creek, Absaroka mountains, Wyoming: Geografiska Annaler Series a-Physical Geography, v. 80A, no. 3-4, p. 267-276.

Anderson, R. S., Anderson, L. S., Armstrong, W. H., Rossi, M. W., and Crump, S. E., 2018, Glaciation of alpine valleys: The glacier - debris-covered glacier - rock glacier continuum: Geomorphology, v. 311, p. 127-142.

Andre, M.-F., 1994, Rock Glaciers in Svalbard. Tentative Dating and Inferred Long-Term Velocities: Geografiska Annaler. Series A, Physical Geography, v. 76, no. 4, p. 235-245.

Angillieri, M. Y. E., 2010, Application of frequency ratio and logistic regression to active rock glacier occurrence in the Andes of San Juan, Argentina: Geomorphology, v. 114, no. 3, p. 396-405.

Aoyama, M., 2005, Rock glaciers in the northern Japanese Alps: palaeoenvironmental implications since the Late Glacial: Journal of Quaternary Science, v. 20, no. 5, p. 471-484.

Arenson, L., Hoelzle, M., and Springman, S., 2002, Borehole deformation measurements and internal structure of some rock glaciers in Switzerland: Permafrost and Periglacial Processes, v. 13, no. 2, p. 117-135.

Arfstrom, J., and Hartmann, W. K., 2005, Martian flow features, moraine-like ridges, and gullies: Terrestrial analogs and interrelationships: Icarus, v. 174, no. 2, p. 321-335.

Assier, A., Evin, M., Fabre, D., 1996. Prospection e' lectrique sur les glaciers rocheux du cirque de Sainte-Anne (Queyras, Alpes du Sud, France). Permafrost and Periglacial Processes v, 7, p. 5367.

Avian, M., Kellerer-Pirklbauer, A., and Bauer, A., 2009, LiDAR for monitoring mass movements in permafrost environments at the cirque Hinteres Langtal, Austria, between 2000 and 2008: Natural Hazards and Earth System Sciences, v. 9, no. 4, p. 1087-1094.

Azócar, G. F., and Brenning, A., 2010, Hydrological and geomorphological significance of rock glaciers in the dry Andes, Chile (27 $\left.-33^{\circ} \mathrm{S}\right)$ : Permafrost and Periglacial Processes, v. 21, no. 1, p. 42-53.

Azocar, G. F., Brenning, A., and Bodin, X., 2017, Permafrost distribution modelling in the semi-arid Chilean Andes: Cryosphere, v. 11, no. 2, p. 877-890. 
Bachrach, T., Jakobsen, K., Kinney, J., Nishimura, P., Reyes, A., Laroque, C. P., and Smith, D. J., 2016, Dendrogeomorphological assessment of movement at hilda rock glacier, banff national park, 
canadian rocky mountains: Geografiska Annaler: Series A, Physical Geography, v. 86, no. 1, p. $1-9$.

Ballantyne, C. K., Schnabel, C., and Xu, S., 2009, Exposure dating and reinterpretation of coarse debris accumulations ('rock glaciers') in the Cairngorm Mountains, Scotland: Journal of Quaternary Science, v. 24, no. 1, p. 19-31.

Ballantyne, C. K., and Stone, J. O., 2016, The Beinn Alligin rock avalanche, NW Scotland: cosmogenic 10Be dating, interpretation and significance: The Holocene, v. 14, no. 3, p. 448-453.

Baltensperger, U., Gaggler, H., Gloor, M., Hoehn, E., and Keil, R., 1990, Chemical composition, Pilot Analyses of Permafrost Cores from the Active Rock Glacier Murtel, Piz Corvatsch, Eastern Swiss Alps. A Workshop Report., Volume 9: Haeberli W Arbeitsheft VAW/ETHZ, p. 24-26.

Barboux, C., Delaloye, R., and Lambiel, C., 2014, Inventorying slope movements in an Alpine environment using DInSAR: Earth Surface Processes and Landforms, v. 39, no. 15, p. 20872099.

Barcaza, G., Nussbaumer, S. U., Tapia, G., Valdes, J., Garcia, J. L., Videla, Y., Albornoz, A., and Arias, V., 2017, Glacier inventory and recent glacier variations in the Andes of Chile, South America: Annals of Glaciology, v. 58, no. 75, p. 166-180.

Baron, J. S., Schmidt, T. M., and Hartman, M. D., 2009, Climate-induced changes in high elevation stream nitrate dynamics: Global Change Biology, v. 15, no. 7, p. 1777-1789.

Baroni, C., Carton, A., and Seppi, R., 2004, Distribution and behaviour of rock glaciers in the Adamello-Presanella Massif(Italian Alps): Permafrost and Periglacial Processes, v. 15, no. 3, p. 243-259.

Barry, R. G., 2008, Mountain Weather an Climate, Cambridge, Cambridge University Press.

Barsch, D., 1977, Nature and importance of mass wasting by rock glaciers in alpine permafrost environments: Earth Surface Processes and Landforms, v. 2, no. 2-3, p. 230-245.

-, 1987, The problem of the ice-cored rock glacier, in Giardino, J. R., Shroder, J. F., and Vitek, J. D., eds., Rock Glaciers: London, Allen and Unwin, p. 45-53.

-, 1988, Rockglaciers, in Clark, M. J., ed., Advances in Periglacial Geomorphology: New York, John Wiley, p. 69-90.

Barsch, D., 1993, Periglacial geomorphology in the $21^{\text {st }}$ century: Geomorphology, v. 7, no. 1-3, p. 141163. 
-, 1996, Rockglaciers: Indicators for the present and former geoecology in high mountain systems, Berlin, Springer, Physical Environment, 331 p.:

Barsch, D., and Caine, N., 1984, The Nature of Mountain Geomorphology: Mountain Research and Development, v. 4, no. 4, p. 287-298.

Barsch, D., Fierz, H., and Haeberli, W., 1979, Shallow Core Drilling and Bore-Hole Measurements in the Permafrost of an Active Rock Glacier near the Grubengletscher, Wallis, Swiss Alps: Arctic and Alpine Research, v. 11, no. 2, p. 215-228.

Barsch, D., and Hell, G., 1975, Photogrammetrische Bewegungmessung am Blockgletscher Murtèl I, Oberengadin, Schweizer Alpen: Zeitschrift für Gletscherkunde und Glazialgeologie, v. 11, no. 2, p. 111-142.

Barsch, D., and Jakob, M., 1998, Mass transport by active rockglaciers in the Khumbu Himalaya: Geomorphology, v. 26, no. 1-3, p. 215-222.

Barsch, D., and King, L., 1975, An attempt to date fossil rock glaciers in Grisons, Swiss Alps (a preliminary note.): Questiones Geographicae (Poznan), v. 2, p. 5-14.

Barsch, D., and Updike, R. G., 1971, Late Pleistocene periglacial geomorphology (rock glaciers and blockfields) at Kendrick Peak, Northern Arizona: Arizona Geological Society Digest, v. 9, p. 225-243.

Barsch, D., and Zick, W., 1991, Die Bewegungen des Blockgletschers Macun I von 1965 - 1988 (Unterengadin, Graubünden, Schweiz): Zeitschrift für Geomorphologie, v. 35, p. 9-14.

Belò, M., D'Agata, C., Guglielmin, M., and Smiraglia, C., The use of GPS measurements to define the surface morphology of a rock glacier. The case of Foscagno Rock Glacier (Italian Central Alps), 
in Proceedings 10th Alpine Glaziology Meeting, Munich, 2006, Commission for Glaciology of the Bavarian Academy of Sciences and Humanities.

Benedict, J. B., 1973, Origin of rock glaciers: Journal of Glaciology, v. 12, p. 520-522.

Benedict, J. B., 2005, Rethinking the fourth of July Valley site: A study in glacial and periglacial geoarchaeology: Geoarchaeology, v. 20, no. 8, p. 797-836.

Benedict, J. B., Benedict, R. J., and Sanville, D., 1986, Arapaho Rock Glacier, Front Range, Colorado, U.S.A.: A 25-Year Resurvey: Arctic and Alpine Research, v. 18, no. 3, p. 349-352.

Beniston, M., 2000, Environmental Change in Mountains and Uplands, New York, Oxford University Press, Key issues in environmental change., 172 p.:

Berthling, I., 2011, Beyond confusion: Rock glaciers as cryo-conditioned landforms: Geomorphology, v. 131, no. 3-4, p. 98-106.

Berthling, I., Etzelmüller, B., Eiken, T., and Sollid, J. L., 1998, Rock glaciers on Prins Karls Forland, Svalbard. I: internal structure, flow velocity and morphology: Permafrost and Periglacial Processes, v. 9, no. 2, p. 135-145.

Berthling, I., Etzelm?ller, B., Isaksen, K., and Sollid, J. L., 2000, Rock Glaciers on Prins Karls Forland. II: GPR Soundings and the Development of Internal Structures: Permafrost and Periglacial Processes, v. 11, no. 4, p. 357-369.

Bickerton, R. W., and Matthews, J. A., 1992, On the accuracy of lichenometric dates: an assessment based on the 'Little Ice Age' moraine sequence of Nigardsbreen, southern Norway: The Holocene, v. 2, no. 3, p. 227-237.

Blöthe, J. H., Rosenwinkel, S., Höser, T., and Korup, O., 2019, Rock-glacier dams in High Asia: Earth Surface Processes and Landforms, v. 44, no. 3, p. 808-824.

Bodin, X., Krysiecki, J.-M., Schoeneich, P., Le Roux, O., Lorier, L., Echelard, T., Peyron, M., and Walpersdorf, A., 2017, The 2006 Collapse of the Bérard Rock Glacier (Southern French Alps): Permafrost and Periglacial Processes, v. 28, no. 1, p. 209-223.

Bodin, X., Thibert, E., Fabre, D., Ribolini, A., Schoeneich, P., Francou, B., Reynaud, L., and Fort, M., 2009, Two decades of responses (1986-2006) to climate by the Laurichard rock glacier, French Alps: Permafrost and Periglacial Processes, v. 20, no. 4, p. 331-344.

Bolch, T., and Gorbunov, A. P., 2014, Characteristics and Origin of Rock Glaciers in Northern Tien Shan (Kazakhstan/Kyrgyzstan): Permafrost and Periglacial Processes, v. 25, no. 4, p. 320-332. 
Bolch, T., and Marchenko, S. S., Significance of glaciers, rockglaciers and ice-rich permafrost in the Northern Tien Shan as water towers under climate change conditions, in Proceedings Selected papers from the Workshop "Assessment of Snow, Glacier and Water Resources in Asia", Almaty, Kazakhstan 28-30 Nov. 2006, 2009, Volume 8, IHP/HWRP-Berichte, p. 132-144.

Bolch, T., Rohrbach, N., Kutuzov, S., Robson, B. A., and Osmonov, A., 2019, Occurrence, evolution and ice content of ice-debris complexes in the Ak-Shiirak, Central Tien Shan revealed by 
geophysical and remotely-sensed investigations: Earth Surface Processes and Landforms, v. 44, no. 1, p. 129-143.

Bolch, T., and Schröder, H., 2001, Geomorphologische Kartierung und Diversitätsbestimmung der Periglazialformen am Cerro Sillajhuay (Chile/Bolivien), Erlangen, Erlanger Geographische Arbeiten. Fränkische Geographische Gesellschaft.

Bolch, T., and Strel, A., Evolution of rock glaciers in northern Tien Shan, Central Asia, 1971 - 2016, in Proceedings 5th European Conference on Permafrost, Chamonix, France, 2018, Laboratoire EDYTEM, p. 48-49.

Borowicz, D., and Żurawek, R., 2016, Topography of a composite relict rock glacier, ślęża massif, sw poland: Geografiska Annaler: Series A, Physical Geography, v. 85, no. 1, p. 31-41.

Bosson, J. B., and Lambiel, C., 2016, Internal Structure and Current Evolution of Very Small DebrisCovered Glacier Systems Located in Alpine Permafrost Environments: Frontiers in Earth Science, v. 4, p. 17.

Bradwell, T., and Armstrong, R. A., 2007, Growth rates ofRhizocarpon geographicum lichens: a review with new data from Iceland: Journal of Quaternary Science, v. 22, no. 4, p. 311-320.

Brardinoni, F., Scotti, R., Sailer, R., and Mair, V., 2019, Evaluating sources of uncertainty and variability in rock glacier inventories: Earth Surface Processes and Landforms, v. 44, no. 12, p. 2450-2466.

Brazier, V., Kirkbride, M. P., and Owens, I. F., 2016, The relationship between climate and rock glacier distribution in the ben ohau range, new zealand: Geografiska Annaler: Series A, Physical Geography, v. 80, no. 3-4, p. 193-207.

Brenning, A., 2005, Geomorphological, hydrological and climatic significance of rock glaciers in the Andes of Central Chile (33-35 S): Permafrost and Periglacial Processes, v. 16, no. 3, p. 231-240.

Brenning, A., 2005, Climatic and geomorphological controls of rock glaciers in the Andes of Central Chile: Combining statistical modelling and field mapping: Humboldt Universität zu Berlin.

Brenning, A., 2009, Benchmarking classifiers to optimally integrate terrain analysis and multispectral remote sensing in automatic rock glacier detection: Remote Sensing of Environment, v. 113, no. 1, p. 239-247. 
Brenning, A., and Azócar, G. F., 2010, Statistical analysis of topographic and climatic controls and multispectral signatures of rock glaciers in the dry Andes, Chile $\left(27^{\circ}-33^{\circ} \mathrm{S}\right)$ : Permafrost and Periglacial Processes, v. 21, no. 1, p. 54-66.

Brenning, A., Grasser, M., and Friend, D. A., 2007, Statistical estimation and generalized additive modeling of rock glacier distribution in the San Juan Mountains, Colorado, United States: Journal of Geophysical Research, v. 112, no. F2.

Brenning, A., and Trombotto, D., 2006, Logistic regression modeling of rock glacier and glacier distribution: Topographic and climatic controls in the semi-arid Andes: Geomorphology, v. 81, no. 1-2, p. 141-154.

Brighenti, S., Tolotti, M., Bruno, M. C., Engel, M., Wharton, G., Cerasino, L., Mair, V., and Bertoldi, W., 2019, After the peak water: the increasing influence of rock glaciers on alpine river systems: Hydrological Processes, v. 33, no. 21, p. 2804-2823.

Brown, W. H., 1925, A probable fossil glacier: Journal of Geology, v. 33, no. 5, p. 464-466.

Bryant, B., 1971, Movement measurements on two rock glaciers in the eastern Elk Mountains, Colorado: US Geological Survey, Professional Paper, v. 750-B, p. B108-116.

Buchli, T., Kos, A., Limpach, P., Merz, K., Zhou, X., and Springman, S. M., 2018, Kinematic investigations on the Furggwanghorn Rock Glacier, Switzerland: Permafrost and Periglacial Processes, v. 29, no. 1, p. 3-20.

Buckel, J., Reinosch, E., Hördt, A., Zhang, F., Riedel, B., Gerke, M., Schwalb, A., and Mäusbacher, R., 2021, Insights into a remote cryosphere: a multi-method approach to assess permafrost 
occurrence at the Qugaqie basin, western Nyainqêntanglha Range, Tibetan Plateau: The Cryosphere, v. 15, no. 1, p. 149-168.

Bucki, A. K., and Echelmeyer, K. A., 2017, The flow of Fireweed rock glacier, Alaska, U.S.A: Journal of Glaciology, v. 50, no. 168, p. 76-86.

Bucki, A. K., Echelmeyer, K. A., and MacInnes, S., 2017, The thickness and internal structure of Fireweed rock glacier, Alaska, U.S.A., as determined by geophysical methods: Journal of Glaciology, v. 50, no. 168, p. 67-75.

Burga, C. A., Frauenfelder, R., Ruffet, J., Hoelzle, M., and Kääb, A., 2004, Vegetation on Alpine rock glacier surfaces: a contribution to abundance and dynamics on extreme plant habitats: Flora Morphology, Distribution, Functional Ecology of Plants, v. 199, no. 6, p. 505-515.

Burger, K. C., Degenhardt, J. J., and Giardino, J. R., 1999, Engineering geomorphology of rock glaciers: Geomorphology, v. 31, no. 1-4, p. 93-132.

Caine, N., 1974, The Geomorphic Processes of the Alpine Environment, in Ives, J. D., and Barry, R., eds., Arctic and Alpine environments: New York, Harper \& Row Publishers, p. 721-748.

-, 1984, Elevational contrasts in contemporary geomorphic activity in the Colorado Front Range: Studia Geomorphologica Carpatho-Balcanica, v. 18, p. 5-30.

-, 1986, Sediment movement and storage on alpine slopes in the Colorado Rocky Mountains, in Abrahams, A. D., ed., Hillslope Processes: Winchester, MA, Allen and Unwin, p. 115-137.

Calderoni, G., Guglielmin, M., and Tellini, C., 1998, Radiocarbon dating and postglacial evolution, upper Valtellina and Livignese area (Sondrio, Central Italian Alps): Permafrost and Periglacial Processes, v. 9, no. 3, p. 275-284.

Calkin, P. E., and Ellis, J. M., 1980, A Lichenometric Dating Curve and Its Application to Holocene Glacier Studies in the Central Brooks Range, Alaska: Arctic and Alpine Research, v. 12, no. 3, p. 245-264.

Calkin, P. E., Haworth, L. A., and Ellis, J. M., 1987, Rock glaciers of Central Brooks Range, Alaska, U.S.A., in Giardino, J. R., Shroder, J. F., and Vitek, J. D., eds., Rock Glaciers: London, Allen and Unwin, p. 65-82.

Calkin, P. E., Kaufman, D. S., Przybyl, B. J., Whitford, W. B., and Peck, B. J., 1998, Glacier Regimes, Periglacial Landforms, and Holocene Climate Change in the Kigluaik Mountains, Seward Peninsula, Alaska, U.S.A: Arctic and Alpine Research, v. 30, no. 2, p. 154-165. 
Cannone, N., and Gerdol, R., 2003, Vegetation as an Ecological Indicator of Surface Instability in Rock Glaciers: Arctic, Antarctic, and Alpine Research, v. 35, no. 3, p. 384-390.

Capps, S., 1910, Rock glaciers in Alaska: Journal of Geology, v. 18, p. 359-375.

Capt, M., Bosson, J. B., Fischer, M., Micheletti, N., and Lambiel, C., 2016, Decadal evolution of a very small heavily debris-covered glacier in an Alpine permafrost environment: Journal of Glaciology, v. 62, no. 233, p. 535-551.

Carter, R., LeRoy, S., Nelson, T., Laroque, C. P., and Smith, D. J., 2002, Dendroglaciological investigations at Hilda Creek rock glacier, Banff National Park, Canadian Rocky Mountains: Géographie physique et Quaternaire, v. 53, no. 3, p. 365-371.

Charbonneau, A. A., and Smith, D. J., 2018, An inventory of rock glaciers in the central British Columbia Coast Mountains, Canada, from high-resolution Google Earth imagery: Arctic, Antarctic, and Alpine Research, v. 50, no. 1.

Chueca, J., and Julián, A., 2005, Movement of Besiberris Rock Glacier, Central Pyrenees, Spain: Data from a 10-Year Geodetic Survey: Arctic, Antarctic, and Alpine Research, v. 37, no. 2, p. 163170.

Cicoira, A., Beutel, J., Faillettaz, J., and Vieli, A., 2019, Water controls the seasonal rhythm of rock glacier flow: Earth and Planetary Science Letters, v. 528.

Clark, D. H., Clark, M. M., and Gillespie, A. R., 2017, Debris-Covered Glaciers in the Sierra Nevada, California, and Their Implications for Snowline Reconstructions: Quaternary Research, v. 41, no. 2, p. 139-153.

Clark, D. H., Steig, E. J., Potter, j. N., and Gillespie, A. R., 2016, Genetic variability of rock glaciers: Geografiska Annaler: Series A, Physical Geography, v. 80, no. 3-4, p. 175-182.

Clark, D. H., Steig, E. J., Potter, N., Fitzpatrick, J. J., Updike, A. B., and Clark, M. G., 1996, Old ice in rock glaciers may provide long-term climate records: EOS, Transactions, American Geophysical Union, v. 77, no. 23, p. 217-222.

Colombo, N., Salerno, F., Gruber, S., Freppaz, M., Williams, M., Fratianni, S., and Giardino, M., 2018, Review: Impacts of permafrost degradation on inorganic chemistry of surface fresh water: Global and Planetary Change, v. 162, p. 69-83.

Colucci, R. R., Boccali, C., Zebre, M., and Guglielmin, M., 2016, Rock glaciers, protalus ramparts and pronival ramparts in the south-eastern Alps: Geomorphology, v. 269, p. 112-121. 
Corte, A., 1987, Rock glacier taxonomy, in Giardino, J. R., Shroder, J. F., and Vitek, J. D., eds., Rock Glaciers: Boston, Allen and Unwin, p. 27-39.

Cremonese, E., Gruber, S., Phillips, M., Pogliotti, P., Boeckli, L., Noetzli, J., Suter, C., Bodin, X., Crepaz, A., Kellerer-Pirklbauer, A., Lang, K., Letey, S., Mair, V., Morra di Cella, U., Ravanel, L., Scapozza, C., Seppi, R., and Zischg, A., 2011, Brief Communication: \&quot;An inventory of permafrost evidence for the European Alps\&quot: The Cryosphere, v. 5, no. 3, p. 651-657.

Croce, F. A., and Milana, J. P., 2002, Internal structure and behaviour of a rock glacier in the Arid Andes of Argentina: Permafrost and Periglacial Processes, v. 13, no. 4, p. 289-299.

Cross, C. W., and Howe, E., 1905, Geography and general geology of the quadrangle in Silverton Folio: US Geological Survey Folio, v. 120, p. 1-25.

Cui, Z., and Cheng, Z., Rock glaciers in the source region of Urumqi River, middle Tian Shan, China, in Proceedings V International Conference on Permafrost Trondheim, Norway, 1988, Volume 1, p. 724-727.

Dall'Asta, E., Forlani, G., Roncella, R., Santise, M., Diotri, F., and di Cella, U. M., 2017, Unmanned Aerial Systems and DSM matching for rock glacier monitoring: Isprs Journal of Photogrammetry and Remote Sensing, v. 127, p. 102-114.

de Sanjosé-Blasco, J., Atkinson-Gordo, A. D. J., Salvador-Franch, F., and Gómez-Ortiz, A., 2007, Application of geomatic techniques to monitoring of the dynamics and to mapping of the Veleta rock glacier (Sierra Nevada, Spain): Zeitschrift für Geomorphologie, Supplementary Issues, v. 51, no. 2, p. 79-89.

Degenhardt, J. J., 2003, Subsurface investigation of a rock glacier using ground-penetrating radar: Implications for locating stored water on Mars: Journal of Geophysical Research, v. 108, no. E4.

-, 2009, Development of tongue-shaped and multilobate rock glaciers in alpine environments Interpretations from ground penetrating radar surveys: Geomorphology, v. 109, no. 3-4, p. 94107.

Delaloye, R., Morard, S., Barboux, C., Abbert, D., Gruber, V., Riedo, M., and Gacet, S., Rapidly moving rock glaciers in Mattertal, in Proceedings Mattertal - ein Tal in Bewegung. Publikation 
zur Jahrestagung der Schweizerischen Geomorphologischen Gesellschaft 29. Juni - 1. Juli 2011, Birmensdorf, 2013, St. Niklaus, p. 21-32.

Deline, P., 2015, Chapter 15 - Ice Loss and Slope Stability in High-Mountain Regions, in Haeberli, W., Whiteman, C., and Shroder, J. F., eds., Snow and Ice-Related Hazards, Risks and Disasters: Boston, Academic Press, p. 521-561.

Deline, P., Gruber, S., Amann, F., Bodin, X., Delaloye, R., Failletaz, J., Fischer, L., Geertsema, M., Giardino, M., and Hasler, A., 2021, Ice loss from glaciers and permafrost and related slope 
instability in high-mountain regions, Snow and Ice-Related Hazards, Risks, and Disasters, Elsevier, p. 501-540.

Elconin, R. F., and LaChapelle, E. R., 2017, Flow and internal structure of a rock glacier: Journal of Glaciology, v. 43, no. 144, p. 238-244.

Emmert, A., and Kneisel, C., 2017, Internal structure of two alpine rock glaciers investigated by quasi-3D electrical resistivity imaging: The Cryosphere, v. 11, no. 2, p. 841-855.

Esper Angillieri, M. Y., 2009, A preliminary inventory of rock glaciers at $30^{\circ} \mathrm{S}$ latitude, Cordillera Frontal of San Juan, Argentina: Quaternary International, v. 195, no. 1-2, p. 151-157.

Etzelmüller, B., Farbrot, H., Guðmundsson, Á., Humlum, O., Tveito, O. E., and Björnsson, H., 2007, The regional distribution of mountain permafrost in Iceland: Permafrost and Periglacial Processes, v. 18, no. 2, p. 185-199.

Evin, M., 1987, Lithology and fracturing control of rock glaciers in southwestern Alps of France and Italy, in Giardino, J. R., Shroder, J. F., and Vitek, J. D., eds., Rock Glaciers: Boston, Allen and Unwin, p. 83-106.

Evin, M., Fabre, D., and Johnson, P. G., 1997, Electrical resistivity measurements on the rock glaciers of Grizzly Creek, St Elias Mountains, Yukon: Permafrost and Periglacial Processes, v. 8, no. 2, p. 181-191.

Fabre, D., Francou, B., Jomelli, V., Kaiser, B., Arnaud, Y., Pouyaud, B., Smiraglia, C., and Valla, F., 2001, The analysis of a rock glacier structure in the tropical area (Caquella, South-Lipez, Bolivia): Houille Blanche-Revue Internationale De L Eau, no. 3-4, p. 124-132.

Faillettaz, J., Funk, M., Beutel, J., and Vieli, A., 2019, Towards early warning of gravitational slope failure with co-detection of microseismic activity: the case of an active rock glacier: Natural Hazards and Earth System Sciences, v. 19, no. 7, p. 1399-1413.

Falaschi, D., Castro, M., Masiokas, M., Tadono, T., and Ahumada, A. L., 2014, Rock Glacier Inventory of the Valles Calchaquíes Region $\left(\sim 25^{\circ} \mathrm{S}\right)$, Salta, Argentina, Derived from ALOS Data: Permafrost and Periglacial Processes, v. 25, no. 1, p. 69-75.

Falaschi, D., Tadono, T., and Masiokas, M., 2016, Rock glaciers in the patagonian andes: an inventory for the monte san lorenzo (cerro cochrane) massif, $47^{\circ}$ s: Geografiska Annaler: Series A, Physical Geography, v. 97, no. 4, p. 769-777. 
Farbrot, H., Etzelmüller, B., Guðmundsson, Á., Humlum, O., Kellerer-Pirklbauer, A., Eiken, T., and Wangensteen, B., 2007, Rock glaciers and permafrost in Trollaskagi, northern Iceland: Zeitschrift für Geomorphologie, Supplementary Issues, v. 51, no. 2, p. 1-16.

Fegel, T. S., Baron, J. S., Fountain, A. G., Johnson, G. F., and Hall, E. K., 2016, The differing biogeochemical and microbial signatures of glaciers and rock glaciers: Journal of Geophysical Research-Biogeosciences, v. 121, no. 3, p. 919-932.

Fey, C., and Wichmann, V., 2017, Long-range terrestrial laser scanning for geomorphological change detection in alpine terrain - handling uncertainties: Earth Surface Processes and Landforms, v. 42, no. 5, p. 789-802.

Francou, B., Fabre, D., Pouyaud, B., Jomelli, V., and Arnaud, Y., 1999, Symptoms of degradation in a tropical rock glacier, Bolivian Andes: Permafrost and Periglacial Processes, v. 10, no. 1, p. 91 100.

Francou, B., and Reynaud, L., 1992, 10 years of surficial velocities on a rock glacier (Laurichard, French Alps), Permafrost and Periglacial Processes, Vol 3, No 3, Jul-Sept 1992: Permafrost and Periglacial Environments in Mountain Areas, 209-213 p.:

Frauenfelder, R., Haeberli, W., Hoelzle, M., and Maisch, M., 2001, Using relict rockglaciers in GISbased modellng to reconstruct Younger Dryas permafrost distribution patterns in the Err-Julier 
area, Swiss Alps: Norsk Geografisk Tidsskrift - Norwegian Journal of Geography, v. 55, p. 195202.

Frauenfelder, R., and Kaab, A., 2000, Towards a palaeoclimatic model of rock-glacier formation in the Swiss Alps, in Steffen, K., ed., Annals of Glaciology, Vol 31, 2000, Volume 31, p. 281-286.

Frauenfelder, R., Schneider, B., and Kääb, A., 2008, Using dynamic modelling to simulate the distribution of rockglaciers: Geomorphology, v. 93, no. 1-2, p. 130-143.

Fukui, K., Fujii, Y., Mikhailov, N., Ostanin, O., and Iwahana, G., 2007, The lower limit of mountain permafrost in the Russian Altai Mountains: Permafrost and Periglacial Processes, v. 18, no. 2, p. 129-136.

Fukui, K., Sone, T., Strelin, J. A., Torielli, C. A., Mori, J., and Fujii, Y., 2017, Dynamics and GPR stratigraphy of a polar rock glacier on James Ross Island, Antarctic Peninsula: Journal of Glaciology, v. 54, no. 186, p. 445-451.

Gärtner-Roer, I., 2012, Sediment transfer rates of two active rockglaciers in the Swiss Alps: Geomorphology, v. 167-168, p. 45-50.

Geiger, S. T., Daniels, J. M., Miller, S. N., and Nicholas, J. W., 2014, Influence of rock glaciers on stream hydrology in the La Sal Mountains, Utah: Arctic Antarctic and Alpine Research, v. 46, no. 3, p. 645-658.

Gerhold, N., 1964, Die Blockgletscher-eine besondere Moranenform?Ph.D.]: University of Innsbruck, $200 \mathrm{p}$.

Gerrard, J., 1990, Mountain Environments: An Examination of the Physical Geography of Mountains, Cambridge, Mass., MIT Press, vii, 317 p.:

Giardino, J. R., 1979, Rock glacier mechanics and chronologies: Mt. Mestas, Colorado [Ph.D. Dissertation: University of Nebraska, $244 \mathrm{p}$.

Giardino, J. R., Shroder, J. F., and Lawson, M. P., 1984, Tree-Ring Analysis of Movement of a RockGlacier Complex on Mount Mestas, Colorado, U.S.A: Arctic and Alpine Research, v. 16, no. 3, p. 299-309.

Giardino, J. R., and Vick, S. G., 1987, Geologic engineering aspects of rock glaciers, in Giardino, J. R., F. Shroder, and J. D. Vitek, ed., Rock Glaciers: Boston, Allen and Unwin, p. 265-287.

Giardino, J. R., and Vitek, J., 1988a, The Significance of Rock Glaciers in the Glacial-Periglacial Landscape Continuum: Journal of Quarternary Science, v. 3, p. 97-103. 
Giardino, J. R., and Vitek, J. D., 1988b, Interpreting the Internal Fabric of a Rock Glacier: Geografiska Annaler. Series A, Physical Geography, v. 70, no. 1/2, p. 15-25.

Giardino, J. R., Vitek, J. D., and Demorett, J. L., 1992, A model of water movement in rock glaciers and associated water characteristics. In:(eds), Periglacial Geomorphology, in Dixon, J. C., and Abrahams, A. D., eds., 1st ed. Routledge, p. 159-184.

Goloskokov, V., 1949, Derevnije ledniki v Zaillijskom Atalau (Wooden glaciers in Zailiyskiy Alatau): Vostochnik Akadamia Nauk KasSSR, v. 1, p. 80-82.

Gomez Ortiz, A., Salvador Franch, F., Schulte, L., Sanjose Blasco, J. J., Atkinson Gordo, A., and Palacios Estremera, D., 2008, Morphodynamic evolution in recent deglaciated high mountain areas: The case of the Veleta Cirque, Sierra Nevada. Consequence of climate change?: Scripta Nova-Revista Electronica De Geografia Y Ciencias Sociales, v. 12, no. 270.

Gomez-Gutierrez, A., de Sanjose-Blasco, J. J., de Matias-Bejarano, J., and Berenguer-Sempere, F., 2014, Comparing Two Photo-Reconstruction Methods to Produce High Density Point Clouds and DEMs in the Corral del Veleta Rock Glacier (Sierra Nevada, Spain): Remote Sensing, v. 6, no. 6 , p. $5407-5427$.

Gorbunov, A. P., and Titkov, S. N., 1989, Kamennye Gletchery Gor Srednej Azii (Rock glaciers of the Central Asian mountains), Irkutsk, Akademia Nauk SSSR.

-, 1992, Dynamics of rock glaciers of the northern Tien Shan and the Djungar Ala Tau, Kazakhstan: Permafrost and Periglacial Processes, v. 3, p. 29-39.

Grab, S. W., 1996, The occurrence of a holocene rock glacier on Mount Kenya: Some observations and comments: Permafrost and Periglacial Processes, v. 7, no. 4, p. 381-389.

Graf, C., Deubelbeiss, Y., Bühler, Y., Meier, L., McArdell, B., Christen, M., and Bartelt, P., Gefahrenkartierung Mattertal: Grundlagenbeschaffung und numerische Modellierung von Murgängen, in Proceedings Mattertal - ein Tal in Bewegung. Publikation zur Jahrestagung der 
Schweizerischen Geomorphologischen Gesellschaft 29. Juni - 1. Juli 2011, St. Niklaus, 2013, Birmensdorf, p. 85-112.

Group, I. A., 2020, IPA Action Group Rock glacier inventories and kinematics: Towards standard guidelines for inventorying rock glaciers: Baseline concepts (Version 4.1).

Gruber, S., and Haeberli, W., 2007, Permafrost in steep bedrock slopes and its temperature-related destabilization following climate change: Journal of Geophysical Research, v. 112, no. F2.

Guglielmin, M., Camusso, M., Polesello, S., and Valsecchi, S., 2004, An Old Relict Glacier Body Preserved in Permafrost Environment: The Foscagno Rock Glacier Ice Core (Upper Valtellina, Italian Central Alps): Arctic, Antarctic, and Alpine Research, v. 36, no. 1, p. 108-116.

Guglielmin, M., Cannone, N., and Dramis, F., 2001, Permafrost-glacial evolution during the Holocene in the Italian Central Alps: Permafrost and Periglacial Processes, v. 12, no. 1, p. 111-124.

Guglielmin, M., Lozej, A., and Tellini, C., 1994, Permafrost distribution and rock glaciers in the livigno area (Northern Italy): Permafrost and Periglacial Processes, v. 5, no. 1, p. 25-36.

Haeberli, W., Permafrost-glacier relationships in the Swiss Alps-today and in the past, in Proceedings Proceedings of the 4th International Conference on Permafrost1983, Volume 1, National Academy Press, Washington, p. 415-420.

-, 1985, Creep of mountain permafrost: internal structure and flow of alpine rock glaciers: Mitteilungen der Versuchsanstalt für Wasserbau, Hydrologie und Glaziologie, v. 77, p. 142.

-, 1990, Glacier and permafrost signals of $20^{\text {th }}$-century warming: Annals of Glaciology, v. 14, p. 99-101.

-, Accelerated glacier and permafrost changes in the Alps, in Proceedings Proceedings of the International Conference on Mountain Environments in Changing Climates, Davos, Switzerland, 1992, Routledge, London, p. 91-107.

-, 1994, Accelerated glacier and permafrost changes in the Alps, in Beniston, M., ed., Mountain Environments and Changing Climates: New York, Routledge, p. 91-107.

Haeberli, W., 2000, Modern Research Perspectives Relating to Permafrost Creep and Rock Glaciers: A Discussion: Permafrost and Periglacial Processes, v. 11, no. 4, p. 290-293.

Haeberli, W., Brandova, D., Burga, C., Egli, M., Frauenfelder, R., Kaab, A., Maisch, M., Mauz, B., and Dikau, R., 2003, Methods for absolute and relative age dating of rock-glacier surfaces in alpine permafrost, Permafrost, Vols 1 and 2, 343-348 p.: 
Haeberli, W., Frauenfelder, R., Hoelzle, M., and Maisch, M., 1999, On Rates and Acceleration Trends of Global Glacier Mass Changes: Geografiska Annaler, Series A: Physical Geography, v. 81, no. 4, p. 585-591.

Haeberli, W., Hallet, B., Arenson, L., Elconin, R., Humlum, O., Kääb, A., Kaufmann, V., Ladanyi, B., Matsuoka, N., Springman, S., and Mühll, D. V., 2006, Permafrost creep and rock glacier dynamics: Permafrost and Periglacial Processes, v. 17, no. 3, p. 189-214.

Haeberli, W., Huder, J., Keusen, H. R., Pika, J., and Rothlisberger, H., Core drilling through rock glacier permafrost, in Proceedings Proceedings of the 5th International Conference on Permafrost, Trondheim, 1988, Volume 2, Tapir, p. 937-942.

Haeberli, W., Kääb, A., Mühll, D. V., and Teysseire, P., 2017, Prevention of outburst floods from periglacial lakes at Grubengletscher, Valais, Swiss Alps: Journal of Glaciology, v. 47, no. 156, p. 111-122.

Haeberli, W., King, L., and Flotron, A., 1979, Surface Movement and Lichen-Cover Studies at the Active Rock Glacier near the Grubengletscher, Wallis, Swiss Alps: Arctic and Alpine Research, v. 11 , no. 4 , p. $421-441$.

Haeberli, W., and Schmid, W., Aerophotogrammetrical monitoring of rock glaciers, in Proceedings Proceedings of the 5th International Conference on Permafrost, Trondheim, Norway, 1988, Volume 1, p. 764-769.

Haeberli, W., and Vonder Mühll, D., 1996, On the characteristics and possible origins of ice in rock glacier permafrost: Zeitschrift für Geomorphologie, v. 104, p. 43-57.

Halla, C., Blöthe, J. H., Tapia Baldis, C., Trombotto Liaudat, D., Hilbich, C., Hauck, C., and Schrott, L., 2021, Ice content and interannual water storage changes of an active rock glacier in the dry Andes of Argentina: The Cryosphere, v. 15, no. 2, p. 1187-1213.

Hamilton, S. J., and Brian Whalley, W., 1995, Rock glacier nomenclature: A re-assessment: Geomorphology, v. 14, no. 1, p. 73-80.

Hanson, S., and Hoelzle, M., 2004, The thermal regime of the active layer at the Murtèl rock glacier based on data from 2002: Permafrost and Periglacial Processes, v. 15, no. 3, p. 273-282.

Harrington, J. S., Mozil, A., Hayashi, M., and Bentley, L. R., 2018, Groundwater flow and storage processes in an inactive rock glacier: Hydrological Processes, v. 32, no. 20, p. 3070-3088. 
Harris, C., 2005, Climate Change, Mountain Permafrost Degradation and Geotechnical Hazard, in Huber, U. M., Bugmann, H. K. M., and Reasoner, M. A., eds., Global Change and Mountain Regions. An Overview of Current Knowledge: Dordrecht, Springer, p. 215-224.

Harris, S. A., 1994, Climatic Zonality of Periglacial Landforms in Mountain Areas: Arctic, v. 47, no. 2, p. 184-192.

Harrison, S., Jones, D., Anderson, K., Shannon, S., and Betts, R. A., 2021, Is ice in the Himalayas more resilient to climate change than we thought?: Geografiska Annaler: Series A, Physical Geography, v. 103, no. 1, p. 1-7.

Harrison, S., Whalley, B., and Anderson, E., 2008, Relict rock glaciers and protalus lobes in the British Isles: implications for Late Pleistocene mountain geomorphology and palaeoclimate: Journal of Quaternary Science, v. 23, no. 3, p. 287-304.

Hauck, C., Böttcher, M., and Maurer, H., 2011, A new model for estimating subsurface ice content based on combined electrical and seismic data sets: The Cryosphere, v. 5, no. 2, p. 453-468.

Hauck, C., and Mühll, D. V., 2003, Inversion and interpretation of two-dimensional geoelectrical measurements for detecting permafrost in mountainous regions: Permafrost and Periglacial Processes, v. 14, no. 4, p. 305-318.

Hauck, C., Vonder Mühll, D., and Maurer, H., 2003, Using DC resistivity tomography to detect and characterize mountain permafrost: Geophysical Prospecting, v. 51, no. 4, p. 273-284.

Hausmann, H., Krainer, K., Brückl, E., and Mostler, W., 2007, Internal structure and ice content of Reichenkar rock glacier (Stubai Alps, Austria) assessed by geophysical investigations: Permafrost and Periglacial Processes, v. 18, no. 4, p. 351-367.

Head, J. W., and Marchant, D. R., 2003, Cold-based mountain glaciers on Mars: Western Arsia Mons: Geology, v. 31, no. 7, p. 641-644.

Hétu, B., and Gray, J. T., 2000, Effects of environmental change on scree slope development throughout the postglacial period in the Chic-Choc Mountains in the northern Gaspé Peninsula, Québec: Geomorphology, v. 32, no. 3-4, p. 335-355.

Heuberger, H., 2001, Rockglaciers - indicators for the present and former geoecology in high mountain environments: Mitteilungen Der Osterreichischen Geographischen Gesellschaft, v. 143, p. 368370. 
Holt, J. W., Safaeinili, A., Plaut, J. J., Head, J. W., Phillips, R. J., Seu, R., Kempf, S. D., Choudhary, P., Young, D. A., Putzig, N. E., Biccari, D., and Gim, Y., 2008, Radar sounding evidence for buried glaciers in the southern mid-latitudes of Mars: Science, v. 322, no. 5905, p. 1235-1238.

Hubbard, B., Milliken, R. E., Kargel, J. S., Limaye, A., and Souness, C., 2011, Geomorphological characterisation and interpretation of a mid-latitude glacier-like form: Hellas Planitia, Mars: Icarus, v. 211, no. 1, p. 330-346.

Hughes, P. D., Gibbard, P. L., and Woodward, J. C., 2003, Relict rock glaciers as indicators of Mediterranean palaeoclimate during the Last Glacial Maximum (Late Würmian) in northwest Greece: Journal of Quaternary Science, v. 18, no. 5, p. 431-440.

Hughes, P. D., Woodward, J. C., and Gibbard, P. L., 2006, The last glaciers of Greece: Zeitschrift Fur Geomorphologie, v. 50, no. 1, p. 37-61.

Humlum, O., 1996, Origin of rock glaciers: Observations from Mellemfjord, Disko Island, Central West Greenland: Permafrost and Periglacial Processes, v. 7, no. 4, p. 361-380.

-, 1997, Active layer thermal regime at three rock glaciers in Greenland: Permafrost and Periglacial Processes, v. 8, no. 4, p. 383-408.

-, 1998, The climatic significance of rock glaciers: Permafrost and Periglacial Processes, v. 9, no. 4, p. 375-395.

-, 2000, The geomorphic significance of rock glaciers: estimates of rock glacier debris volumes and headwall recession rates in West Greenland: Geomorphology, v. 35, no. 1-2, p. 41-67.

-, 2016, Late-Holocene climate in central West Greenland: meteorological data and rock-glacier isotope evidence: The Holocene, v. 9, no. 5, p. 581-594.

Huss, M., and Hock, R., 2018, Global-scale hydrological response to future glacier mass loss: Nature Climate Change, v. 8, no. 2, p. 135-140.

Ikeda, A., 2006, Combination of conventional geophysical methods for sounding the composition of rock glaciers in the Swiss Alps: Permafrost and Periglacial Processes, v. 17, no. 1, p. 35-48.

Ikeda, A., and Matsuoka, N., 2002, Degradation of talus-derived rock glaciers in the Upper Engadin, Swiss Alps: Permafrost and Periglacial Processes, v. 13, no. 2, p. 145-161.

-, 2006, Pebbly versus bouldery rock glaciers: Morphology, structure and processes: Geomorphology, v. 73, no. 3-4, p. 279-296. 
Ikeda, A., Matsuoka, N., and Kääb, A., 2008, Fast deformation of perennially frozen debris in a warm rock glacier in the Swiss Alps: An effect of liquid water: Journal of Geophysical Research, v. 113, no. F1.

Ilyashuk, B. P., Ilyashuk, E. A., Psenner, R., Tessadri, R., and Koinig, K. A., 2014, Rock Glacier Outflows May Adversely Affect Lakes: Lessons from the Past and Present of Two Neighboring Water Bodies in a Crystalline-Rock Watershed: Environmental Science \& Technology, v. 48, no. 11, p. 6192-6200.

Imhof, M., 1996, Modelling and verification of the permafrost distribution in the Bernese Alps (Western Switzerland): Permafrost and Periglacial Processes, v. 7, no. 3, p. 267-280.

Immerzeel, W. W., Lutz, A. F., Andrade, M., Bahl, A., Biemans, H., Bolch, T., Hyde, S., Brumby, S., Davies, B. J., Elmore, A. C., Emmer, A., Feng, M., Fernandez, A., Haritashya, U., Kargel, J. S., Koppes, M., Kraaijenbrink, P. D. A., Kulkarni, A. V., Mayewski, P. A., Nepal, S., Pacheco, P., Painter, T. H., Pellicciotti, F., Rajaram, H., Rupper, S., Sinisalo, A., Shrestha, A. B., Viviroli, D., 
Wada, Y., Xiao, C., Yao, T., and Baillie, J. E. M., 2020, Importance and vulnerability of the world's water towers: Nature, v. 577, no. 7790, p. 364-369.

Ingelrest, F., Barrenetxea, G., Schaefer, G., Vetterli, M., Couach, O., and Parlange, M., 2010, SensorScope: ACM Transactions on Sensor Networks, v. 6, no. 2, p. 1-32.

Isaksen, K., Odegard, R. S., Eiken, T., and Sollid, J. L., 2000, Composition, flow and development of two tongue-shaped rock glaciers in the permafrost of Svalbard: Permafrost and Periglacial Processes, v. 11, no. 3, p. 241-257.

Ishikawa, M., Watanabe, T., and Nakamura, N., 2001, Genetic differences of rock glaciers and the discontinuous mountain permafrost zone in Kanchanjunga Himal, Eastern Nepal: Permafrost and Periglacial Processes, v. 12, no. 3, p. 243-253.

Ives, R. L., 1940, Rock glaciers in the Colorado Front Range: Geological Society of America Bulletin, v. 51, p. 1271-1294.

Jäckli, H., 1956, Gegenwartsgeologie des bundnerischen Rheingebietes-ein Beitrag zur exogenen Dyanmik alpiner Gebirgslandschaften: Beitrage zur Geologie der Schweiz, Geotech Series, v. 36, p. 126.

Janke, J., and Frauenfelder, R., 2008, The relationship between rock glacier and contributing area parameters in the Front Range of Colorado: Journal of Quaternary Science, v. 23, no. 2, p. 153163.

Janke, J. R., 2001, Rock glacier mapping: a method utilizing enhanced TM data and GIS modeling techniques: Geocarto International, v. 16, no. 3, p. 5-15.

Janke, J. R., 2005, Modeling past and future alpine permafrost distribution in the Colorado Front Range: Earth Surface Processes and Landforms, v. 30, no. 12, p. 1495-1508.

-, 2005, The occurrence of alpine permafrost in the Front Range of Colorado: Geomorphology, v. 67, no. 3-4, p. 375-389.

-, 2007, Colorado Front Range Rock Glaciers: Distribution and Topographic Characteristics: Arctic, Antarctic, and Alpine Research, v. 39, no. 1, p. 74-83.

-, 2013, Long-Term Flow Measurements (1961-2002) of the Arapaho, Taylor, and Fair Rock Glaciers, Front Range, Colorado: Physical Geography, v. 26, no. 4, p. 313-336.

Janke, J. R., 2016, Photogrammetric analysis of front range rock glacier flow rates: Geografiska Annaler: Series A, Physical Geography, v. 87, no. 4, p. 515-526. 
Janke, J. R., Bellisario, A. C., and Ferrando, F. A., 2015, Classification of debris-covered glaciers and rock glaciers in the Andes of central Chile: Geomorphology, v. 241, p. 98-121.

Jansen, F., and Hergarten, S., 2006, Rock glacier dynamics: Stick-slip motion coupled to hydrology: Geophysical Research Letters, v. 33, no. 10, p. n/a-n/a.

Jarman, D., Wilson, P. and Harrison, S., 2013, Are there any relict rock glaciers in the British mountains? Journal of Quaternary Science: Published for the Quaternary Research Association, $28(2), 131-143$.

Johnson, B. G., Thackray, G. D., and Van Kirk, R., 2007, The effect of topography, latitude, and lithology on rock glacier distribution in the Lemhi Range, central Idaho, USA: Geomorphology, V. 91 , no. $1-2$, p. $38-50$.

Johnson, P. G., 1974, Mass movement of ablation complexes and their relationship to rock glaciers: Geografiska Annaler Series A-Physical Geography, v. 56A, p. 93-101.

-, 1987, Rock glaciers: glaciers debris systems or high magnitude low-frequency flows, in Giardino, J. R., Shroder, J. F., and Vitek, J. D., eds., Rock Glaciers: London, Allen and Unwin, p. 175-192.

Jones, D. B., Harrison, S., Anderson, K., and Betts, R. A., 2018, Mountain rock glaciers contain globally significant water stores: Sci Rep, v. 8, no. 1, p. 2834.

Jones, D. B., Harrison, S., Anderson, K., Selley, H. L., Wood, J. L., and Betts, R. A., 2018, The distribution and hydrological significance of rock glaciers in the Nepalese Himalaya: Global and Planetary Change, v. 160, p. 123-142.

Jones, D. B., Harrison, S., Anderson, K., and Whalley, W. B., 2019, Rock glaciers and mountain hydrology: A review: Earth-Science Reviews, v. 193, p. 66-90.

Kääb, A., 1998, Rock glaciers Gruben, Muragl and Murtel, Switzerland: Area-wide flow fields, National Snow and Ice Data Center/World Data Center for Glaciology., Boulder, CO.

Kääb, A., 2002, Monitoring high-mountain terrain deformation from repeated air- and spaceborne optical data: examples using digital aerial imagery and ASTER data: ISPRS Journal of Photogrammetry and Remote Sensing, v. 57, no. 1-2, p. 39-52.

-, 2008, Remote sensing of permafrost-related problems and hazards: Permafrost and Periglacial Processes, v. 19, no. 2, p. 107-136.

Kääb, A., Gudmundsson, G. H., and Hoelzle, M., Surface deformation of creeping mountain permafrost. Photogrammetric investigations on Murtèl rock glacier, Swiss Alps, in Proceedings Proceedings 
of the 7th International Conference on Permafrost, Yellowknife, Canada, 1998, Volume 3, Nordicana, p. 531-537.

Kääb, A., Haeberli, W., and Gudmundsson, G. H., 1997, Analysing the creep of mountain permafrost using high precision aerial photogrammetry: 25 years of monitoring Gruben rock glacier, Swiss Alps: Permafrost and Periglacial Processes, v. 8, no. 4, p. 409-426.

Kaab, A., Huggel, C., Fischer, L., Guex, S., Paul, F., Roer, I., Salzmann, N., Schlaefli, S., Schmutz, K., Schneider, D., Strozzi, T., and Weidmann, Y., 2005, Remote sensing of glacier- and permafrostrelated hazards in high mountains: an overview: Natural Hazards and Earth System Sciences, v. 5, no. 4, p. 527-554.

Kääb, A., and Kneisel, C., 2006, Permafrost creep within a recently deglaciated glacier forefield: Muragl, Swiss Alps: Permafrost and Periglacial Processes, v. 17, no. 1, p. 79-85.

Kääb, A., and Reichmuth, T., 2005, Advance mechanisms of rock glaciers: Permafrost and Periglacial Processes, v. 16, no. 2, p. 187-193.

Kääb, A., Strozzi, T., Bolch, T., Caduff, R., Trefall, H., Stoffel, M., and Kokarev, A., 2021, Inventory and changes of rock glacier creep speeds in Ile Alatau and Kungöy Ala-Too, northern Tien Shan, since the 1950s: The Cryosphere, v. 15, no. 2, p. 927-949.

Kääb, A., and Vollmer, M., 2000, Surface Geometry, Thickness Changes and Flow Fields on Creeping Mountain Permafrost: Automatic Extraction by Digital Image Analysis: Permafrost and Periglacial Processes, v. 11, no. 4, p. 315-326.

Kääb, A., and Weber, M., 2004, Development of transverse ridges on rock glaciers: field measurements and laboratory experiments: Permafrost and Periglacial Processes, v. 15, no. 4, p. 379-391.

Kaufmann, V., Deformation analysis of the Doesen Rock Glacier (Austria), in Proceedings Proceedings of the 7th International Conference on Permafrost, Yellowknife, Canada, 1998, Volume 57, Nordicana, p. 551-556.

Kaufmann, V., and Ladstädter, R., Spatio-temporal analysis of the dynamic behaviour of the Hochebenkar rock glaciers (Oetztal Alps, Austria) by means of digital photogrammetric methods, in Proceedings Proceedings of the 6th International Symposium on High Mountain 
Remote Sensing Cartography, Addis Ababa, Ethiopia, 2002, Volume 37, Institute of Geography and Regional Science, University of Graz. Graz, Austria, p. 119-139.

Kellerer-Pirklbauer, A., 2007, Lithology and the distribution of rock glaciers: NiedereTauern Range, Styria, Austria: Zeitschrift für Geomorphologie, Supplementary Issues, v. 51, no. 2, p. 17-38.

Kellerer-Pirklbauer, A., Lieb, G. K., and Kleinferchner, H., 2012, A New Rock Glacier Inventory of the Eastern European Alps Austrian Journal of Earth Sciences, v. 105, no. 2, p. 78-93.

Kellerer-Pirklbauer, A., Wangensteen, B., Farbrot, H., and Etzelmüller, B., 2008, Relative surface agedating of rock glacier systems near Hólar in Hjaltadalur, northern Iceland: Journal of Quaternary Science, v. 23, no. 2, p. 137-151.

Kenner, R., Buhler, Y., Delaloye, R., Ginzler, C., and Phillips, M., 2014, Monitoring of high alpine mass movements combining laser scanning with digital airborne photogrammetry: Geomorphology, v. 206, p. 492-504.

Kenner, R., Phillips, M., Beutel, J., Hiller, M., Limpach, P., Pointner, E., and Volken, M., 2017, Factors Controlling Velocity Variations at Short-Term, Seasonal and Multiyear Time Scales, Ritigraben 
Rock Glacier, Western Swiss Alps: Permafrost and Periglacial Processes, v. 28, no. 4, p. 675684.

Kenyi, L. W., and Kaufmann, V., 2003, Estimation of rock glacier surface deformation using sar interferometry data: IEEE Transactions on Geoscience and Remote Sensing, v. 41, no. 6, p. $1512-1515$.

Kerschner, H., 1985, Quantitative paleoclimatic inferences from lateglacial snowline, timberline and rock glacier data, Tyrolean Alps, Austria: Zeitschrift für Gletscherkunde und Glazialgeologie, v. 21, p. 363-369.

King, L., Fisch, W., Haeberli, W., and Waechter, H. P., 1987, Comparison of resistivity and radio-echo soundings on rock-glacier permafrost: Zeitschrift für Gletscherkunde und Glazialgeologie, v. 23, no. 1, p. 77-97.

Kirkbride, M., and Brazier, V., 1995, On the sensitivity of Holocene talus-derived rock glaciers to climate change in the Ben Ohau Range, New Zealand: Journal of Quaternary Science, v. 10, no. 4, p. 353-365.

Kirkbride, M. P., and Dugmore, A. J., 2001, Timing and significance of mid-Holocene glacier advances in northern and central Iceland: Journal of Quaternary Science, v. 16, no. 2, p. 145-153.

Kneisel, C., 2003, Electrical resistivity tomography as a tool for geomorphological investigations - some case studies, in Schrott, L., Hoerdt, A., and Dikau, R., eds., Geophysical Methods in Geomorphology, Volume 132, Zeitschrift fur Geomorphologie: Supplement, p. 145-159.

Kneisel, C., Hauck, C., Fortier, R., and Moorman, B., 2008, Advances in geophysical methods for permafrost investigations: Permafrost and Periglacial Processes, v. 19, no. 2, p. 157-178.

Kneisel, C., and Kääb, A., 2007, Mountain permafrost dynamics within a recently exposed glacier forefield inferred by a combined geomorphological, geophysical and photogrammetrical approach: Earth Surface Processes and Landforms, v. 32, no. 12, p. 1797-1810.

Kneisel, C., Rothenbühler, C., Keller, F., and Haeberli, W., 2007, Hazard assessment of potential periglacial debris flows based on GIS-based spatial modelling and geophysical field surveys: a case study in the Swiss Alps: Permafrost and Periglacial Processes, v. 18, no. 3, p. 259-268.

Kofler, C., Steger, S., Mair, V., Zebisch, M., Comiti, F., and Schneiderbauer, S., 2020, An inventorydriven rock glacier status model (intact vs. relict) for South Tyrol, Eastern Italian Alps: Geomorphology, v. 350. 
Koning, D. M., and Smith, D. J., 1999, Movement of King's Throne rock glacier, Mount Rae area, Canadian Rocky Mountains: Permafrost and Periglacial Processes, v. 10, no. 2, p. 151-162.

Konrad, S. K., and Clark, D. H., 1998, Evidence for an Early Neoglacial Glacier Advance from Rock Glaciers and Lake Sediments in the Sierra Nevada, California, U.S.A: Arctic and Alpine Research, v. 30, no. 3, p. 272-284.

Konrad, S. K., and Humphrey, N. F., 2000, Steady-state flow model of debris-covered glaciers (rock glaciers), in Nakawo, M., Raymond, C. F., and Fountain, A., eds., Debris-Covered Glaciers, p. 255-263.

Konrad, S. K., Humphrey, N. F., Steig, E. J., Clark, D. H., Potter, N., and Pfeffer, W. T., 1999, Rock glacier dynamics and paleoclimatic implications: Geology, v. 27, no. 12, p. 1131-1134.

Krainer, K., Bressan, D., Dietre, B., Haas, J. N., Hajdas, I., Lang, K., Mair, V., Nickus, U., Reidl, D., Thies, H., and Tonidandel, D., 2015, A 10,300-year-old permafrost core from the active rock glacier Lazaun, southern Otztal Alps (South Tyrol, northern Italy): Quaternary Research, v. 83, no. 2, p. 324-335.

Krainer, K., Bressan, D., Dietre, B., Haas, J. N., Hajdas, I., Lang, K., Mair, V., Nickus, U., Reidl, D., Thies, H., and Tonidandel, D., 2017, A 10,300-year-old permafrost core from the active rock 
glacier Lazaun, southern Ötztal Alps (South Tyrol, northern Italy): Quaternary Research, v. 83, no. 2, p. 324-335.

Krainer, K., and He, X., 2016, Flow velocities of active rock glaciers in the austrian alps: Geografiska Annaler: Series A, Physical Geography, v. 88, no. 4, p. 267-280.

Krainer, K., and Mostler, W., 2000, Reichenkar rock glacier: a glacier derived debris-ice system in the western Stubai Alps, Austria: Permafrost and Periglacial Processes, v. 11, no. 3, p. 267-275.

-, 2002, Hydrology of Active Rock Glaciers: Examples from the Austrian Alps: Arctic, Antarctic, and Alpine Research, v. 34, no. 2, p. 142-149.

Krainer, K., and Ribis, M., 2012, A ROCK GLACIER INVENTORY OF THE TYROLEAN ALPS (AUSTRIA): Austrian Journal of Earth Sciences, v. 105, no. 2, p. 32-47.

Krautblatter, M., Moser, M., Schrott, L., Wolf, J., and Morche, D., 2012, Significance of rockfall magnitude and carbonate dissolution for rock slope erosion and geomorphic work on Alpine limestone cliffs (Reintal, German Alps): Geomorphology, v. 167-168, p. 21-34.

Lambiel, C., and Delaloye, R., 2004, Contribution of real-time kinematic GPS in the study of creeping mountain permafrost: examples from the Western Swiss Alps: Permafrost and Periglacial Processes, v. 15, no. 3, p. 229-241.

Lecomte, K. L., Milana, J. P., Formica, S. M., and Depetris, P. J., 2008, Hydrochemical appraisal of iceand rock-glacier meltwater in the hyperarid Agua Negra drainage basin, Andes of Argentina: Hydrological Processes, v. 22, no. 13, p. 2180-2195.

Lewis, C. A., and Hanvey, P. M., 2010, The Remains of Rock Glaciers in Bottelnek, East Cape Drakensberg, South Africa: Transactions of the Royal Society of South Africa, v. 48, no. 2, p. 265-289.

Lindner, L., and Marks, L., 1985, TYPES OF DEBRIS SLOPE ACCUMULATIONS AND ROCK GLACIERS IN SOUTH SPITSBERGEN: Boreas, v. 14, no. 2, p. 139-153.

Liu, L., Millar, C. I., Westfall, R. D., and Zebker, H. A., 2013, Surface motion of active rock glaciers in the Sierra Nevada, California, USA: inventory and a case study using InSAR: The Cryosphere, v. 7, no. 4, p. 1109-1119.

Marcer, M., Bodin, X., Brenning, A., Schoeneich, P., Charvet, R., and Gottardi, F., 2017, Permafrost Favorability Index: Spatial Modeling in the French Alps Using a Rock Glacier Inventory: Frontiers in Earth Science, v. 5, p. 17. 
Martin, H. E., and Whalley, W. B., 1987, ROCK GLACIERS .1. ROCK GLACIER MORPHOLOGY CLASSIFICATION AND DISTRIBUTION: Progress in Physical Geography, v. 11, no. 2, p. 260-282.

Matsuoka, N., Ikeda, A., and Date, T., 2005, Morphometric analysis of solifluction lobes and rock glaciers in the Swiss Alps: Permafrost and Periglacial Processes, v. 16, no. 1, p. 99-113.

Maurer, H., and Hauck, C., 2017, Geophysical imaging of alpine rock glaciers: Journal of Glaciology, v. 53 , no. 180 , p. 110-120.

Merz, K., Maurer, H., Buchli, T., Horstmeyer, H., Green, A. G., and Springman, S. M., 2015, Evaluation of Ground-Based and Helicopter Ground-Penetrating Radar Data Acquired Across an Alpine Rock Glacier: Permafrost and Periglacial Processes, v. 26, no. 1, p. 13-27.

Messerli, B., and Zurbuchen, M., 1968, Blockgletscher im Weissmies und Aletsch und ihre photogrammetrische Kartierung: Die Alpen, SAC, v. 3, p. 139-152.

Millar, C. I., and Westfall, R. D., 2008, Rock glaciers and related periglacial landforms in the Sierra Nevada, CA, USA; inventory, distribution and climatic relationships: Quaternary International, v. 188 , no. 1 , p. $90-104$.

-, 2018, Distribution and Climatic Relationships of the American Pika (Ochotona princeps) in the Sierra Nevada and Western Great Basin, U.S.A.; Periglacial Landforms as Refugia in Warming Climates: Arctic, Antarctic, and Alpine Research, v. 42, no. 1, p. 76-88.

Milliken, R. E., 2003, Viscous flow features on the surface of Mars: Observations from high-resolution Mars Orbiter Camera (MOC) images: Journal of Geophysical Research, v. 108, no. E6.

Monnier, S., 2007, From glacier to rock glacier, since the end of the Little Ice Age, at the foot of the Mont Thabor (northern French Alps): Quaternaire, v. 18, no. 3, p. 283-294.

Monnier, S., and Kinnard, C., 2013, Internal structure and composition of a rock glacier in the Andes (upper Choapa valley, Chile) using borehole information and ground-penetrating radar: Annals of Glaciology, v. 54, no. 64, p. 61-72.

-, 2017, Pluri-decadal (1955-2014) evolution of glacier-rock glacier transitional landforms in the central Andes of Chile (30-33 degrees S): Earth Surface Dynamics, v. 5, no. 3, p. 493-509.

Moore, P. L., 2014, Deformation of debris-ice mixtures: Reviews of Geophysics, v. 52, no. 3, p. 435467. 
Moran, A. P., Ivy Ochs, S., Vockenhuber, C., and Kerschner, H., 2016, Rock glacier development in the Northern Calcareous Alps at the Pleistocene-Holocene boundary: Geomorphology, v. 273, p. 178-188.

Morris, S. E., 1981, Topoclimatic Factors and the Development of Rock Glacier Facies, Sangre de Cristo Mountains, Southern Colorado: Arctic and Alpine Research, v. 13, no. 3, p. 329-338.

Müller, J., Gärtner-Roer, I., Kenner, R., Thee, P., and Morche, D., 2014, Sediment storage and transfer on a periglacial mountain slope (Corvatsch, Switzerland): Geomorphology, v. 218, p. 35-44.

Müller, J., Vieli, A., and Gärtner-Roer, I., 2016, Rock glaciers on the run - understanding rock glacier landform evolution and recent changes from numerical flow modeling: The Cryosphere, v. 10, no. 6 , p. 2865-2886.

Musil, M., Maurer, H., Green, A. G., Horstmeyer, H., Nitsche, F. O., Mühll, D. V., and Springman, S., 2002, Shallow seismic surveying of an Alpine rock glacier: Geophysics, v. 67, no. 6, p. 17011710.

Musil, M., Maurer, H., Hollinger, K., and Green, A. G., 2006, Internal structure of an alpine rock glacier based on crosshole georadar traveltimes and amplitudes: Geophysical Prospecting, v. 54, no. 3, p. 273-285.

Necsoiu, M., Onaca, A., Wigginton, S., and Urdea, P., 2016, Rock glacier dynamics in Southern Carpathian Mountains from high-resolution optical and multi-temporal SAR satellite imagery: Remote Sensing of Environment, v. 177, p. 21-36.

Nicholas, J. W., 1994, Fabric analysis of rock glacier debris mantles, La Sal Mountains, Utah: Permafrost and Periglacial Processes, v. 5, no. 1, p. 53-66.

Nicholas, J. W., and Butler, D. R., 1996, Application of Relative-Age Dating Techniques on Rock Glaciers of the La Sal Mountains, Utah: An Interpretation of Holocene Paleoclimates: Geografiska Annaler. Series A, Physical Geography, v. 78, no. 1, p. 1-18.

Nicholas, J. W., and Garcia, J. E., 2013, Origin of Fossil Rock Glaciers, La Sal Mountains, Utah: Physical Geography, v. 18, no. 2, p. 160-175.

NSIDC, 1999, updated 2009, National Snow and Ice Data Center: World glacier inventory, World Glacier Monitoring Service and National Snow and Ice Data Center/World Data Center for Glaciology, Boulder, CO. 
Nyenhuis, M., Hoelzle, M., and Dikau, R., 2005, Rock glacier mapping and permafrost distribution modelling in the Turtmanntal, Valais, Switzerland: Zeitschrift Fur Geomorphologie, v. 49, no. 3, p. 275-292.

Ødegård, R. S., Isaksen, K., Eiken, T., and Ludvig Sollid, J., 2003, Terrain analyses and surface velocity measurements of the Hiorthfjellet rock glacier, Svalbard: Permafrost and Periglacial Processes, v. 14 , no. 4 , p. 359-365.

Onaca, A., Ardelean, F., Urdea, P., and Magori, B., 2017, Southern Carpathian rock glaciers: Inventory, distribution and environmental controlling factors: Geomorphology, v. 293, p. 391-404.

Osborn, G., 1985, MOVEMENT OF ICE-CEMENTED ROCK GLACIERS BY HYDROSTATICPRESSURE - AN EXAMPLE FROM MOUNT MESTAS, COLORADO: Zeitschrift Fur Geomorphologie, v. 29, no. 3, p. 373-374.

Otto, J.-C., Schrott, L., Jaboyedoff, M., and Dikau, R., 2009, Quantifying sediment storage in a high alpine valley (Turtmanntal, Switzerland): Earth Surface Processes and Landforms, v. 34, no. 13, p. $1726-1742$.

Otto, J. C., Kleinod, K., König, O., Krautblatter, M., Nyenhuis, M., Roer, I., Schneider, M., Schreiner, B., and Dikau, R., 2016, HRSC-A data: a new high-resolution data set with multipurpose 
applications in physical geography: Progress in Physical Geography: Earth and Environment, v. 31, no. 2, p. 179-197.

Otto, J. C., and Sass, O., 2006, Comparing geophysical methods for talus slope investigations in the Turtmann valley (Swiss Alps): Geomorphology, v. 76, no. 3-4, p. 257-272.

Outcalt, S. I., and Benedict, J. B., 1965, Photo-interpretation of two types of rock glaciers in the Colorado Front Range, U.S.A.: Journal of Glaciology, v. 5, p. 849-856.

Palmentola, G., Baboci, K., Gruda, G. J., and Zito, G., 1995, A note on rock glaciers in the Albanian Alps: Permafrost and Periglacial Processes, v. 6, no. 3, p. 251-257.

Pancza, A., 1998, Les bourrelets-protalus: liens entre les eboulis et les glaciers rocheux: Permafrost and Periglacial Processes, v. 9, no. 2, p. 167-175.

Parson, C. G., 1987, Rock glaciers and site characteristics of the Blanca Massif, Colorado, USA, in Giardino, J. R., Shroder, J. F., and Vitek, J. D., eds., Rock Glaciers: Boston, Allen and Unwin, p. 127-143.

Perucca, L., and Esper Angillieri, Y., 2008, A preliminary inventory of periglacial landforms in the Andes of La Rioja and San Juan, Argentina, at about $28^{\circ}$ S: Quaternary International, v. 190, no. 1, p. 171-179.

Petersen, E. I., Levy, J. S., Holt, J. W., and Stuurman, C. M., 2019, New insights into ice accumulation at Galena Creek Rock Glacier from radar imaging of its internal structure: Journal of Glaciology, v. 66 , no. 255 , p. 1-10.

Piermattei, L., Carturan, L., de Blasi, F., Tarolli, P., Dalla Fontana, G., Vettore, A., and Pfeifer, N., 2016, Suitability of ground-based SfM-MVS for monitoring glacial and periglacial processes: Earth Surface Dynamics, v. 4, no. 2, p. 425-443.

Pillewizer, W., 1957, Untersuchungen an Blockströmen der Ötztaler Alpen: Abhandlungen des Geographischen Institutes der Freie Universität Berlin, v. 5, p. 37-50.

Plaut, J. J., Safaeinili, A., Holt, J. W., Phillips, R. J., Head, J. W., Seu, R., Putzig, N. E., and Frigeri, A., 2009, Radar evidence for ice in lobate debris aprons in the mid-northern latitudes of Mars: Geophysical Research Letters, v. 36, no. 2, p. n/a-n/a.

Potter, N., 1972, Ice-cored rock glacier, Galena Creek, Northern Absaroka Mountains, Wyoming: Geological Society of America Bulletin, v. 83, p. 3025-3068. 
Potter, N., Steig, E. J., Clark, D. H., Speece, M. A., Clark, G. M., and Updike, A. B., 1998, Galena Creek rock glacier revisited - New observations on an old controversy: Geografiska Annaler Series a-Physical Geography, v. 80A, no. 3-4, p. 251-265.

Pourrier, J., Jourde, H., Kinnard, C., Gascoin, S., and Monnier, S., 2014, Glacier meltwater flow paths and storage in a geomorphologically complex glacial foreland: The case of the Tapado glacier, dry Andes of Chile (30 degrees S): Journal of Hydrology, v. 519, p. 1068-1083.

Rangecroft, S., Harrison, S., and Anderson, K., 2018, Rock Glaciers as Water Stores in the Bolivian Andes: An Assessment of Their Hydrological Importance: Arctic, Antarctic, and Alpine Research, v. 47, no. 1, p. 89-98.

Rangecroft, S., Harrison, S., Anderson, K., Magrath, J., Castel, A. P., and Pacheco, P., 2013, Climate change and water resources in arid mountains: an example from the Bolivian Andes: Ambio, v. 42, no. 7 , p. 852-863.

Rangecroft, S., Harrison, S., Anderson, K., Magrath, J., Castel, A. P., and Pacheco, P., 2014, A First Rock Glacier Inventory for the Bolivian Andes: Permafrost and Periglacial Processes, v. 25, no. 4, p. 333-343.

Refsnider, K. A., and Brugger, K. A., 2007, Rock Glaciers in Central Colorado, U.S.A., as Indicators of Holocene Climate Change: Arctic, Antarctic, and Alpine Research, v. 39, no. 1, p. 127-136.

Reinosch, E., Gerke, M., Riedel, B., Schwalb, A., Ye, Q., and Buckel, J., 2021, Rock glacier inventory of the western Nyainqêntanglha Range, Tibetan Plateau, supported by InSAR time series and automated classification: Permafrost and Periglacial Processes.

Ribolini, A., and Fabre, D., 2007, Shallow active layer temperature and DC resistivity of a rock glacier in the Argentera Massif, Maritime Alps, Italy: Zeitschrift für Geomorphologie, Supplementary Issues, v. 51, no. 2, p. 55-77.

Ribolini, A., Guglielmin, M., Fabre, D., Bodin, X., Marchisio, M., Sartini, S., Spagnolo, M., and Schoeneich, P., 2010, The internal structure of rock glaciers and recently deglaciated slopes as revealed by geoelectrical tomography: insights on permafrost and recent glacial evolution in the 
Central and Western Alps (Italy-France): Quaternary Science Reviews, v. 29, no. 3-4, p. 507521.

Rignot, E., 2002, Rock glacier surface motion in Beacon Valley, Antarctica, from synthetic-aperture radar interferometry: Geophysical Research Letters, v. 29, no. 12.

Robson, B. A., Bolch, T., MacDonell, S., Hölbling, D., Rastner, P., and Schaffer, N., 2020, Automated detection of rock glaciers using deep learning and object-based image analysis: Remote Sensing of Environment, v. 250.

Roer, I., Haeberli, W., Avian, M., Kaufmann, V., Delaloye, R., Lambiel, C., and Kääb, A., Observations and considerations on destabilizing active rock glaciers in the European Alps, in Proceedings Proceedings of the 9th International Conference on Permafrost2008, p. 1505-1510.

Roer, I., and Nyenhuis, M., 2007, Rockglacier activity studies on a regional scale: comparison of geomorphological mapping and photogrammetric monitoring: Earth Surface Processes and Landforms, v. 32, no. 12, p. 1747-1758.

Sailer, R., and Kerschner, H., 1999, Equilibrium-line altitudes and rock glaciers during the Younger Dryas cooling event, Ferwall group, western Tyrol, Austria, in Kleman, J., ed., Annals of Glaciology, Vol 28, Volume 28, p. 141-145.

Sandeman, A. F., and Ballantyne, C. K., 2008, Talus rock glaciers in Scotland: Characteristics and controls on formation: Scottish Geographical Magazine, v. 112, no. 3, p. 138-146.

Scapozza, C., Lambiel, C., Bozzini, C., Mari, S., and Conedera, M., 2014, Assessing the rock glacier kinematics on three different timescales: a case study from the southern Swiss Alps: Earth Surface Processes and Landforms, v. 39, no. 15, p. 2056-2069.

Scapozza, C., Lambiel, C., Reynard, E., Fallot, J.-M., Antognini, M., and Schoeneich, P., 2010, Radiocarbon dating of fossil wood remains buried by the Piancabella rock glacier, Blenio Valley (Ticino, southern Swiss Alps): Implications for rock glacier, treeline and climate history: Permafrost and Periglacial Processes, v. 21, no. 1, p. 90-96.

Schmid, M. O., Baral, P., Gruber, S., Shahi, S., Shrestha, T., Stumm, D., and Wester, P., 2015, Assessment of permafrost distribution maps in the Hindu Kush Himalayan region using rock glaciers mapped in Google Earth: The Cryosphere, v. 9, no. 6, p. 2089-2099.

Schoeneich, P., Bodin, X., Echelard, T., Kaufmann, V., Kellerer-Pirklbauer, A., Krysiecki, J. M., and Lieb, G. K., 2015, Velocity Changes of Rock Glaciers and Induced Hazards, Engineering 
Geology for Society and Territory, Vol 1: Climate Change and Engineering Geology, 223-227 p.:

Schrott, L., 1991, Global solar radiation, soil temperature and permafrost in the Central Andes, Argentina: A progress report: Permafrost and Periglacial Processes, v. 2, p. 59-66.

Schrott, L., and Sass, O., 2008, Application of field geophysics in geomorphology: Advances and limitations exemplified by case studies: Geomorphology, v. 93, no. 1-2, p. 55-73.

Scotti, R., Brardinoni, F., Alberti, S., Frattini, P., and Crosta, G. B., 2013, A regional inventory of rock glaciers and protalus ramparts in the central Italian Alps: Geomorphology, v. 186, p. 136-149.

Serrano, E., San José, J. J., and Agudo, C., 2006, Rock glacier dynamics in a marginal periglacial high mountain environment: Flow, movement (1991-2000) and structure of the Argualas rock glacier, the Pyrenees: Geomorphology, v. 74, no. 1-4, p. 285-296.

Shean, D. E., Head, J. W., and Marchant, D. R., 2007, Shallow seismic surveys and ice thickness estimates of the Mullins Valley debris-covered glacier, McMurdo Dry Valleys, Antarctica: Antarctic Science, v. 19, no. 4, p. 485-496.

Shroder, J. F., 1987, Rock glaciers and slope failures: High Plateaus and La Sal Mountains, Colorado Plateau, UT, USA., in Giardino, J., Shroder, J. F., and Vitek, J., eds., Rock glaciers: Boston, Allen and Unwin, p. 175-192.

Shroder, J. F., Bishop, M. P., Copland, L., and Sloan, V. F., 2016, Debris-covered glaciers and rock glaciers in the nanga parbat himalaya, pakistan: Geografiska Annaler: Series A, Physical Geography, v. 82, no. 1, p. 17-31.

Shroder, J. F., and Giardino, J. R., 1987, Analysis of rock glaciers in Utah and Colorado U.S.A. using dendrogeomorphological techniques, in Giardino, J., Shroder, J. F., and Vitek, J., eds., Rock Glaciers: Boston, Allen and Unwin, p. 151-159.

Slaymaker, O., and Embleton-Hamann, C., 2018, Advances in global mountain geomorphology: Geomorphology, v. 308, p. 230-264.

Sloan, V. F., and Dyke, L. D., 2016, Decadal and millennial velocities of rock glaciers, selwyn mountains, canada: Geografiska Annaler: Series A, Physical Geography, v. 80, no. 3-4, p. 237249.

Solomina, O., and Calkin, P. E., 2003, Lichenometry as Applied to Moraines in Alaska, U.S.A., and Kamchatka, Russia: Arctic, Antarctic, and Alpine Research, v. 35, no. 2, p. 129-143. 
Spencer, A. C., 1900, A peculiar form of talus: Science, v. 11, p. 188.

Springman, S. M., Arenson, L. U., Yamamoto, Y., Maurer, H., Kos, A., Buchli, T., and Derungs, G., 2016, Multidisciplinary investigations on three rock glaciers in the swiss alps: legacies and future perspectives: Geografiska Annaler: Series A, Physical Geography, v. 94, no. 2, p. 215-243.

Steenstrup, K., 1883, Bidrag til Kjendskab til Bræerne og Bræ-Isen i Nord-Grønland: Medd Grønland, v. 4, p. 69-112.

Steig, E. J., Fitzpatrick, J. J., Potter, j. N., and Clark, D. H., 2016, The geochemical record in rock glaciers: Geografiska Annaler: Series A, Physical Geography, v. 80, no. 3-4, p. 277-286.

Stenni, B., Genoni, L., Flora, O., and Guglielmin, M., 2016, An oxygen isotope record from the Foscagno rock-glacier ice core, Upper Valtellina, Italian Central Alps: The Holocene, v. 17, no. 7, p. 1033-1039.

Strozzi, T., Caduff, R., Jones, N., Barboux, C., Delaloye, R., Bodin, X., Kääb, A., Mätzler, E., and Schrott, L., 2020, Monitoring Rock Glacier Kinematics with Satellite Synthetic Aperture Radar: Remote Sensing, v. 12, no. 3.

Strozzi, T., Kääb, A., and Frauenfelder, R., 2010, Detecting and quantifying mountain permafrost creep from in situ inventory, space-borne radar interferometry and airborne digital photogrammetry: International Journal of Remote Sensing, v. 25, no. 15, p. 2919-2931.

Thies, H., Nickus, U., Mair, V., Tessadri, R., Tait, D., Thaler, B., and Psenner, R., 2007, Unexpected response of high Alpine Lake waters to climate warming: Environ Sci Technol, v. 41, no. 21, p. 7424-7429.

Thies, H., Nickus, U., Tolotti, M., Tessadri, R., and Krainer, K., 2013, Evidence of rock glacier melt impacts on water chemistry and diatoms in high mountain streams: Cold Regions Science and Technology, v. 96, p. 77-85.

Thompson, D. J., 2002, Talus fabric in Tuckerman Ravine, New Hampshire: Evidence for a tongueshaped rock glacier: Géographie physique et Quaternaire, v. 53, no. 1, p. 47-57.

Titkov, S. N., Rock Glaciers and glaciation of the Central Asian Mountains, in Proceedings Proceedings of the 5th International Permafrost Conference, Trondheim, 1988, Volume 1, Tapir Publishers, $\mathrm{p}$. $259-262$.

Troll, C., 1973, High mountain belts between the polar caps and the equator: their definition and lower limit: Arctic and Alpine Research, v. 5, p. A19-A27. 
Urawek, R., 2002, Internal Structure of a relict rock glacier, Ślęża Massif, Southwest Poland: Permafrost and Periglacial Processes, v. 13, no. 1, p. 29-42.

Vere, D. M., and Matthews, J. A., 1985, ROCK GLACIER FORMATION FROM A LATERALMORAINE AT BUKKEHOLSBREEN, JOTUNHEIMEN, NORWAY - A 
SEDIMENTOLOGICAL APPROACH: Zeitschrift Fur Geomorphologie, v. 29, no. 4, p. $397-$ 415.

Vick, S. G., 1987, Significance of landsliding in rock glacier formation and movement, in Giardino, J. R., Shroder, J. F., and Vitek, J. D., eds., Rock Glaciers: Boston, Allen and Unwin, p. 239-264.

Vietoris, L., 1972, Über die Blockgletscher des Äußeren Hochebenkars: Zeitschrift für Gletscherkunde und Glazialgeologie, v. 8, p. 169-188.

Villarroel, C. D., Beliveau, G. T., Forte, A. P., Monserrat, O., and Morvillo, M., 2018, DInSAR for a Regional Inventory of Active Rock Glaciers in the Dry Andes Mountains of Argentina and Chile with Sentinel-1 Data: Remote Sensing, v. 10, no. 10, p. 21.

Vitek, J. D., Deutch, A. L., and Parson, C. G., 2010, Summer Measurements of Dissolved Ion Concentrations in Alpine Streams, Blanca Peak Region, Colorado*: The Professional Geographer, v. 33, no. 4, p. 436-444.

Vitek, J. D., and Giardino, J., 1987, Rock glaciers: a review of the knowledge base, in Giardino, J. R., Shroder, J. F., and Vitek, J. D., eds., Rock Glaciers: Boston, Allen and Unwin, p. 1-26.

Vivero, S., and Lambiel, C., 2019, Monitoring the crisis of a rock glacier with repeated UAV surveys: Geographica Helvetica, v. 74, no. 1, p. 59-69.

Vonder Muhll, D. S., Hauck, C., and Lehmann, F., 2000, Verification of geophysical models in Alpine permafrost using borehole information, in Steffen, K., ed., Annals of Glaciology, Vol 31, 2000, Volume 31, p. 300-306.

Vonder Mühll, D. S., and Klingelé, E. E., 1994, Gravimetrical investigation of ice-rich permafrost within the rock glacier Murtè-Corvatsch (upper Engadin, swiss alps): Permafrost and Periglacial Processes, v. 5, no. 1, p. 13-24.

Wagner, S., 1996, DC resistivity and seismic refraction sounding on rock glacier permafrost in northwest Svalbard: Norsk Geografisk Tidsskrift, v. 50, p. 25-36.

Wahrhaftig, C., and Cox, A., 1959, Rock glaciers in the Alaska Range: Bulletin of the Geologic Society of America, v. 70, p. 383-436.

Walker, H. J., 1993, Geomorphology: the research frontier and beyond-Introduction: Geomorphology, v. 7, no. 1-3, p. 1-7. 
Wang, X., Liu, L., Zhao, L., Wu, T., Li, Z., and Liu, G., 2017, Mapping and inventorying active rock glaciers in the northern Tien Shan of China using satellite SAR interferometry: The Cryosphere, v. 11, no. 2, p. 997-1014.

Washburn, A. L., 1980, Geocryology: A Survey of Periglacial Processes and Environments, New York, John Wiley and Sons Ltd., 406 p.:

Wayne, W. J., 2017, Ice Segregation as an Origin for Lenses of Non-Glacial Ice in "Ice-Cemented" Rock Glaciers: Journal of Glaciology, v. 27, no. 97, p. 506-510.

Whalley, W. B., 1974, Rock glaciers and their formation as part of a glacier debris-transport system: University of Reading $24 \mathrm{p}$.

Whalley, W. B., 2003, Rock glaciers and protalus landforms: Analogous forms and ice sources on Earth and Mars: Journal of Geophysical Research, v. 108, no. E4.

Whalley, W. B., and Azizi, F., 1994, Rheological models of active rock glaciers: Evaluation, critique and a possible test: Permafrost and Periglacial Processes, v. 5, no. 1, p. 37-51.

Whalley, W. B., and Martin, H. E., 2016, Rock glaciers : II models and mechanisms: Progress in Physical Geography: Earth and Environment, v. 16, no. 2, p. 127-186.

Whalley, W. B., Palmer, C. F., Hamilton, S. J., and Martin, H. E., 1995, An Assessment of Rock Glacier Sliding Using Seventeen Years of Velocity Data: Nautardalur Rock Glacier, North Iceland: Arctic and Alpine Research, v. 27, no. 4, p. 345-351.

White, S. E., 1971, Rock glacier studies in the Colorado Front Range, 1961 to 1968: Arctic and Alpine Research, v. 3, p. 43-64.

-, 1975, Additional data on Arapaho rock glacier in Colorado Front Range, U.S.A.: Journal of Glaciology, v. 14, no. 72, p. 529-530.

-, 1987, Differential movement across transverse ridges on Arapaho rock glacier, Colorado Front Range, U.S.A., in Giardino, J. R., Shroder, J. F., and Vitek, J. D., eds., Rock Glaciers: London, Allen and Unwin, p. 145-149.

White, S. E., 2017, Rock Glaciers and Block fields, Review and new data: Quaternary Research, v. 6, no. 1, p. 77-97.

Williams, M. W., Knauf, M., Caine, N., Liu, F., and Verplanck, P. L., 2006, Geochemistry and source waters of rock glacier outflow, Colorado Front Range: Permafrost and Periglacial Processes, v. 17, no. 1, p. 13-33. 
Williams, M. W., Knauf, M., Cory, R., Caine, N., and Liu, F., 2007, Nitrate content and potential microbial signature of rock glacier outflow, Colorado Front Range: Earth Surface Processes and Landforms, v. 32, no. 7, p. 1032-1047.

Wirz, V., Gruber, S., Purves, R. S., Beutel, J., Gärtner-Roer, I., Gubler, S., and Vieli, A., 2016, Shortterm velocity variations at three rock glaciers and their relationship with meteorological conditions: Earth Surface Dynamics, v. 4, no. 1, p. 103-123.

Wirz, V., Gruber, S., Purves, R. S., Beutel, J., Gartner-Roer, I., Gubler, S., and Vieli, A., 2016, Shortterm velocity variations at three rock glaciers and their relationship with meteorological conditions: Earth Surface Dynamics, v. 4, no. 1, p. 103-123.

Wohlfarth, B., Gaillard, M.-J., Haeberli, W., and Kelts, K., 1994, Environment and climate in southwestern Switzerland during the last termination, 15-10 ka BP: Quaternary Science Reviews, v. 13 , no. 4 , p. 361-394. 